\title{
Antimicrobial Peptides: An Update on Classifications and Databases
}

\author{
Ahmer Bin Hafeez ${ }^{1}$, Xukai Jiang ${ }^{2,3}$, Phillip J. Bergen ${ }^{2} \mathbb{D}$ and Yan Zhu ${ }^{2, *} \mathbb{( D}$ \\ 1 Centre of Biotechnology and Microbiology, University of Peshawar, Peshawar 25120, Pakistan; \\ ahmerbenhafeez64@gmail.com \\ 2 Infection and Immunity Program, Department of Microbiology, Biomedicine Discovery Institute, Monash \\ University, Clayton, VIC 3800, Australia; Xukai.Jiang@monash.edu (X.J.); phillip.bergen@monash.edu (P.J.B.) \\ 3 National Glycoengineering Research Center, Shandong University, Qingdao 266237, China \\ * Correspondence: yan.zhu@monash.edu; Tel.: +61-3-9902-9178; Fax: +61-3-9905-6540
}

Citation: Bin Hafeez, A.; Jiang, X; Bergen, P.J.; Zhu, Y. Antimicrobial Peptides: An Update on Classifications and Databases. Int. J. Mol. Sci. 2021, 22, 11691. https:// doi.org/10.3390/ijms222111691

Academic Editor: Giovanna Batoni

Received: 22 September 2021

Accepted: 25 October 2021

Published: 28 October 2021

Publisher's Note: MDPI stays neutral with regard to jurisdictional claims in published maps and institutional affiliations.

Copyright: (C) 2021 by the authors. Licensee MDPI, Basel, Switzerland. This article is an open access article distributed under the terms and conditions of the Creative Commons Attribution (CC BY) license (https:/ / creativecommons.org/licenses/by/ $4.0 /)$.

\begin{abstract}
Antimicrobial peptides (AMPs) are distributed across all kingdoms of life and are an indispensable component of host defenses. They consist of predominantly short cationic peptides with a wide variety of structures and targets. Given the ever-emerging resistance of various pathogens to existing antimicrobial therapies, AMPs have recently attracted extensive interest as potential therapeutic agents. As the discovery of new AMPs has increased, many databases specializing in AMPs have been developed to collect both fundamental and pharmacological information. In this review, we summarize the sources, structures, modes of action, and classifications of AMPs. Additionally, we examine current AMP databases, compare valuable computational tools used to predict antimicrobial activity and mechanisms of action, and highlight new machine learning approaches that can be employed to improve AMP activity to combat global antimicrobial resistance.
\end{abstract}

Keywords: antimicrobial peptide; database; structure; mode of action; machine learning; HMM; BLAST

\section{Introduction}

Antibiotic resistance is a global public health problem. Due to rapidly increasing antibiotic resistance over the past decades, our last-line antimicrobials are beginning to fail and a return to a pre-antibiotic era is a distinct possibility [1,2]. In this environment, research into non-conventional anti-infective agents has intensified, with antimicrobial peptides (AMPs) considered potential drug candidates for the treatment of infections caused by otherwise untreatable microorganisms [3,4]. The first AMP, gramicidin, was discovered in 1939 from the soil bacteria Bacillus brevis and showed in vitro and in vivo antibacterial activity against many Gram-positive bacteria [5,6]. Subsequently, the number of catalogued AMPs, also known as host-defense peptides (HDPs), has increased enormously. Most AMPs are oligopeptides of 5 to 100 amino acids with a positive net charge (typically +2 to +11 ) and a significant proportion (typically $50 \%$ ) of hydrophobic residues $[7,8]$. In mammals, they are active against a wide variety of microbes including bacteria, fungi, and unicellular protozoa, as well as viruses [9-12]. The reported mechanisms of action of AMPs are diverse and generally result in the direct killing of the pathogen, although several AMPs may also kill indirectly via modulating host immune responses [13,14]. An important feature that sets AMPs apart from conventional antibiotics is their attack on multiple low-affinity targets such as bacterial membranes, which is thought to mitigate the development of antimicrobial resistance [15]. AMPs are also amenable to mutagenesis and peptide engineering, properties that have already resulted in the production of numerous compounds with enhanced bioactivity and reduced cytotoxicity [16,17]. In this review, we examine the sources, structures, modes of action, and classifications of AMPs, as well as reasons why the translation of AMPs into the clinic has been slow and how this can be improved. We also review some of the regularly curated and maintained AMP databases 
and highlight important features and tools associated with the prediction, improvement, and activity of AMPs.

\section{Sources of AMPs}

\subsection{Bacteriophage/Viral AMPs}

Bacteriophages (phages) are viruses that infect bacteria. Many phage proteins including endolysins (lysins), virion-associated peptidoglycan hydrolases (VAPGHs), depolymerases, and holins display antibacterial activity [18-20]. These phage AMPs are of two types, namely phage-encoded lytic factors and phage-tail complexes [21].

Phage lysins are peptidoglycan-hydrolyzing enzymes that range in size from 25 to $40 \mathrm{kDa}$ [22]. A detailed description of their mode of action is beyond the scope of this review. Briefly, phage lysins weaken the bacterial cell wall by digesting peptidoglycan, creating holes in the cell wall that permit phage progeny to exit the cell. Lysins are currently being considered as an alternative or adjunct to antibiotics given that they possess a number of distinguishing features: (i) targeting the highly conserved bacterial peptidoglycan which typically results in rapid bactericidal activity, (ii) synergy with cell wall-inhibiting antibiotics, (iii) anti-biofilm activity, and (iv) stability (they can be frozen and lyophilized and are heat stable up to $\sim 50{ }^{\circ} \mathrm{C}$ ) [23-25]. Their activities have been investigated both in vitro and in vivo against a number of Gram-positive and -negative bacteria [26,27]. Examples include PK34 and LysAB2 P3, which exhibit activity against Mycobacterium tuberculosis and Acinetobacter baumannii, respectively [28,29]. Phage lysin PlyV12 exhibits broad bactericidal activity against enterococci and other Gram-positive organisms including Streptococcus pyogenes, Staphylococcus aureus, and group B streptococci [30].

VAPGHs are mostly encoded by double-stranded DNA phages and consist of a Cterminal cell wall binding domain and one or more $N$-terminal catalytic domains [31]. They typically result in rapid bactericidal activity and exhibit near species or genus specificity [32,33], thermostability, and functional modularity [34]. Binding of a VAPGH to a bacterial cell occurs via a specific receptor located on the bacterial cell surface and is followed by local hydrolysis of the cell wall, enabling the phage to inject its genetic materials into the bacterial cell $[19,35]$. VAPGHs can be classified into three categories based on the peptidoglycan cleavage site, namely glycosidases (which cleave one of two glycosidic bonds in peptidoglycan chain), amidases (which cleave amide bonds between $\mathrm{N}$-acetylmuramic acid lactyl groups and stem peptide L-alanines), and endopeptidases (which cleave the peptide bonds within either the stem peptide or cross-link) [36]. Most VAPGHs are glycosidases, an example being the lytic transglycosidase Gp16 from phage T7 which cleaves the $\beta-1,4$-glycosidic bond between $N$-acetylmuramic acid and $N$-acetylD-glucosamine $[37,38]$. VAPGHs exhibit activity against both Gram-positive and -negative bacteria. For example, bacteriophage vB_SauS-phiIPLA88 contains HydH5 and is active against S. aureus [34]. Phage $\phi 6$ contains protein P5 (an endopeptidase), which is active against the Gram-negative bacteria Pseudomonas aeruginosa, Pseudomonas phaseolicola HB10Y, Pseudomonas fluorescens, Pseudomonas putida, Escherichia coli, Salmonella enterica serovar typhimurium, and Proteus vulgaris [39]. Similarly, protein gp21, coded by Xanthomonas oryzae phage Xop411, exhibits killing activity against the Xantomonas genus and the Gram-negative species Stenotrophomonas maltophilia and P. aeruginosa [40].

The phage polysaccharide depolymerases are carbohydrate active enzymes that recognize and degrade polysaccharides of the host bacterial envelope [41]. For example, the genome of Klebsiella phage $\Phi$ K64-1 encodes multiple depolymerases active against a variety of Klebsiella capsular polysaccharides (K1, K11, K21, K25, K30, K35, K64, K69, KN4, and KN5) [42,43], whereas P. putida phage AF is capable of degrading the extracellular polysaccharides involved in the P. putida biofilm matrix [44]. Because of potential antibiofilm effects, depolymerases may be effective against biofilm-forming bacteria, including P. mirabilis, E. coli, S. suis, K. pneumoniae, and P. aeruginosa [45-47].

Holins are small sized hydrophobic proteins ( $<150$ amino acids) involved in regulating the time of bacterial lysis via guiding the phage muramidases to the peptidoglycan layer [48-50]. 
They are classified into two different types based on the type of lesion formed, namely canonical holins and pinholins [50,51]. The canonical holins form large pores in the cytoplasmic membrane and allow the secretion of non-specific endolysins and other proteins into the cytoplasm [51,52]. In contrast, pinholins create small holes in the membrane that lead to depolarization prior to peptidoglycan attack [53]. HolGH15 produced by the S. aureus bacteriophage GH15 possesses broad antibacterial activity against a variety of pathogens including S. aureus, Listeria monocytogenes, Bacillus subtilis, Klebsiella pneumonia, E. coli, and Pseudomonas aeruginosa [54,55]. HolSD produced by Streptomyces avermitilis bacteriophage phiSASD1 exhibit anti-E.coli activity [56].

\subsection{Bacterial AMPs}

\subsubsection{AMPs from Gram-Positive Bacteria}

Both ribosomally and non-ribosomally synthesized AMPs have been reported in Gram-positive bacteria (Figure 1a) [57,58]. Ribosomally synthesized bacterial AMPs are termed bacteriocins [59]. These peptides are only active against bacteria closely related to the producing strain, with the producer having a degree of immunity [60]. Bacteriocins produced by Gram-positive bacteria can be classified into four classes: (I) lantibiotics, (II) non-lantiboitics, (III) large-sized bacteriocins, and (IV) uniquely structured bacteriocins [61]

Class I (lantibiotics) contains small peptides ( $<5 \mathrm{kDa}$; $19-38$ amino acids) which are stable to heat, a wide range of $\mathrm{pH}$ levels and proteolysis [62,63], with activity against primarily Gram-positive bacteria $[61,64]$. Unusual amino acids such as lanthionine and $\beta$-methyllanthionine are incorporated into lantibiotics via post-translational modifications (PTMs; e.g., dehydration, thioethers formation, lysinoalanine bridges, oxidative decarboxylation) to enhance structural stability [65-67]. Lantibiotics are further divided into subclasses Ia and Ib. Subclass Ia includes nisin (the first and most prominent lantibiotic), epidermin, gallidermin, and Pep5 [68]. This subclass consists of positively charged elongated peptides and usually acts by forming pores in bacterial membranes which leads to an efflux of small molecules, dissipation of membrane potential, and, ultimately, arrest of cellular biosynthesis [68]. However, nisin and epidermin have a dual mode of action that also includes interference with cell wall synthesis via binding to lipid II (a precursor of peptidoglycan), thereby inhibiting the transgylcosylation step in peptidoglycan polymerization [69-71]. In addition, binding to lipid II also enhances pore formation [72]. Subclass $\mathrm{Ib}$ consists of negatively charged, globular, and inflexible peptides that inhibit crucial enzymes of the targeted bacteria and includes lacticin 481, cytolysin, and salivaricins [61]. The salivaricins act by first binding to lipid II which is followed by pore formation in the cytoplasmic membrane or interference with cell wall synthesis, ultimately leading to cell death [73-75]. Cytolysin targets membranes and forms pores, causing osmotic lysis of the cell $[76,77]$.

Unlike the Class I lantibiotics, Class II AMPs are non-lanthionine-containing bacteriocins that undergo limited PTM (restricted to bisulfide bridge formation in a few members such as pediocin AcH and PA-1) and therefore do not contain unusual amino acids [78,79]. They are small $(<10 \mathrm{kDa})$, heat stable peptides that act as pore-forming/membranedestabilizing/permeability-increasing bacteriocins [80,81]. Class II bacteriocins can be further classified into four subclasses [82]. Subclass IIa consists of disulfide-containing linear peptides with similar amino acid sequences that exhibit strong anti-listerial activity (e.g., leucocin A, acidocin A, pediocin PA-1, and enterocin P) [83-85]. All members of this class act by permeabilizing the cell membrane. For example, pediocin PA-1 (the same as pediocin $\mathrm{AcH}$ ) from Lactobacillus plantarum or Pediococcus sp. acts by pore formation resulting in dissipation of the proton motive force [86,87]. Subclass Ilb bacteriocins consist of two peptide subunits $(\alpha / \beta)$ in equal proportion which function as a single unit; both are necessary for antimicrobial activity $[79,88]$. Examples include plantaricin EF and JK, NC8, thermophilin 13, lactacin F, and lactococcin G and Q [79]. Subclass IIb bacteriocins act by increasing the permeability of the target bacterial cell membrane to specific small molecules [79]. For example, lacticin $\mathrm{F}$ increases permeability specifically to $\mathrm{K}^{+}$and phosphate [89], whereas lactococcin $\mathrm{G}$ increases permeability to a variety of monovalent cations 
(excluding $\mathrm{H}^{+}$) but not divalent cations or anions [90,91]. Subclass IIc is composed of small cyclic peptides whose $N$ - and $C$-termini are covalently linked [86]. They include enterocin AS-48, gassericin A, acidocin B, circularin A, lactocyclicin $Q$, and uberolysin $[64,92,93]$. The mechanism of action of sublass IIc peptides is similar to that of most bacteriocins, namely permeabilization of the membrane, ion leakage leading to dissipation of the membrane potential, and, ultimately, cell death [94]. All remaining non-characterized bacteriocins in the Class II group share no significant sequence similarity with the other class II bacteriocins and are assigned to subclass IId [61]. Examples include lactococcin A, B, and 972, enterocin L50, and lacticin Q [86].

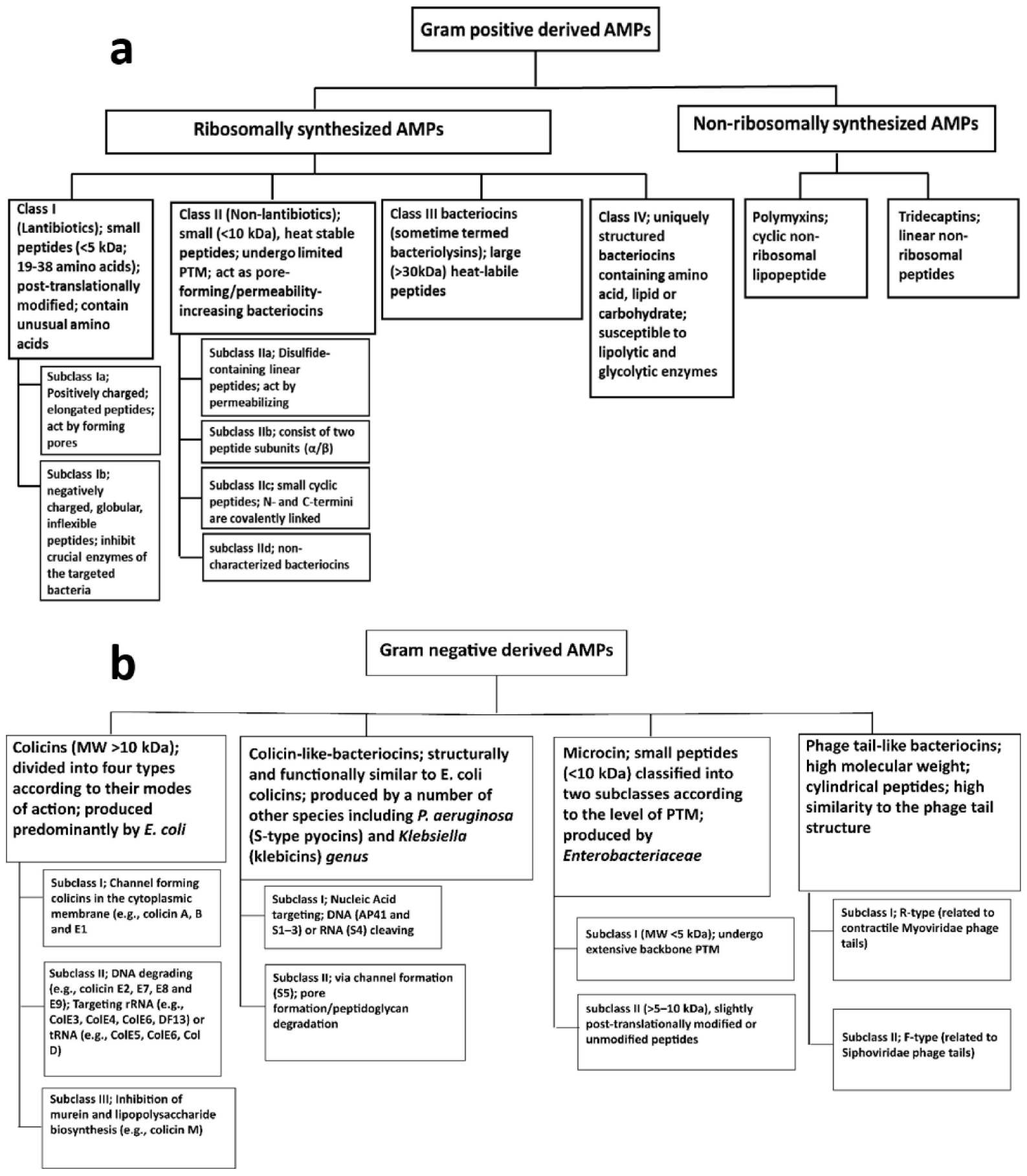

Figure 1. Classification of bacteriocins produced by (a) Gram-positive and (b) Gram-negative bacteria. 
Class III bacteriocins (sometime termed bacteriolysins [82]) consist of large ( $>30 \mathrm{kDa})$, heat-labile peptides [61]. Examples include zoocin A, lysostaphin, enterolysin A, and heleveticin $\mathrm{M}, \mathrm{J}$, and $\mathrm{V}$, which have endopeptidase-like activity against peptidoglycan and cause cell wall disruption [95-97]. Class IV AMPs are uniquely structured bacteriocins containing amino acid and lipid or carbohydrate components that make them susceptible to many lipolytic and glycolytic enzymes $[61,98]$. Examples include plantaricin $\mathrm{S}$ and leuconocin S, lactocin 27, and pediocin SJ-1, which have cell membrane-disrupting activity $[99,100]$.

Polymyxins are a class of cyclic non-ribosomal lipopeptide antibiotics isolated from the Gram-positive spore-forming soil bacterium Paenibacillus polymyxa (previously known as Bacillus polymyxa) [101,102]. They consist of a cyclic heptapeptide with a tripeptide side chain linked to an $\mathrm{N}$-terminal fatty acyl tail [103]. Thus far, 10 different groups of polymyxin lipopeptides have been identified (classified as polymyxins A, B, C, D, E, F, $\mathrm{M}, \mathrm{P}, \mathrm{S}$, and T), although only polymyxin $\mathrm{B}$ and $\mathrm{E}$ (the latter known as colistin) are used clinically [103]. Both polymyxin B and E are active against a range of important Gramnegative bacteria including Enterobacterales as well as A. baumannii, P. aeruginosa, and $S$. maltophilia [103]. Importantly, they retain activity against Gram-negative bacteria listed as Priority 1 (Critical) pathogens by the World Health Organization (WHO) [104]. The known mechanism of action includes disruption of the Gram-negative outer membrane, inhibition of vital respiratory enzymes (type II NADH-quinone oxidoreductases) in the bacterial inner membrane [105], and induction of a hydroxyl radical death pathway [106].

\subsubsection{AMPs from Gram-Negative Bacteria}

To date, the majority of bacteriocins isolated from Gram-negative bacteria have been reported in E. coli, although other species including Klebsiella spp. and Pseudomonas spp. also synthesize AMPs [107]. These chemicals have a narrow spectrum of activity against Gram-negative organisms and can be classified into four classes: colicins, colicin-like, microcins, and phage tail-like bacteriocins (Figure 1b) [61].

The colicins (MW >10 kDa) are produced predominantly by E. coli [108]. Colicins bind to specific cell surface receptors prior to translocation through the outer membrane, periplasm, and inner membrane into the cell cytoplasm [109]; the complicated translocation process has been reviewed by Cascales et al. (2007) and is beyond the scope of this review. Examples of colicin binding include colicin A, K, and U which bind to BtuB, Tsx, and OmpA receptors, respectively [108]. The production of colicins kills not only sensitive neighbouring cells but also the producing cells [109]. Colicins can be divided into four types according to their modes of action: (i) channel formation in the cytoplasmic membrane (e.g., colicin A, B, and E1), (ii) DNA degradation (e.g., colicin E2, E7, E8, and E9), (iii) targeting of rRNA (e.g., ColE3, ColE4, ColE6, and DF13) or tRNA (e.g., ColE5, ColE6, and Col D), and (iv) inhibition of murein and lipopolysaccharide biosynthesis (e.g., colicin M) $[109,110]$. Colicin-like-bacteriocins are structurally and functionally similar to E. coli colicins but are produced by a number of other species including P. aeruginosa (S-type pyocins) and Klebsiella genus (klebicins) [111,112]. S-type pyocins (AP41 and S1-S5) are sensitive to proteases and induce cell death by cleaving DNA (AP41 and S1-S3) or RNA (S4), or via channel formation (S5) [113]. Klebicins act via endonuclease activity, pore formation, and/or peptidoglycan degradation [107,108,112].

Microcins are produced by Enterobacteriaceae and are active against phylogenetically close species $[114,115]$. They consist of small peptides $(<10 \mathrm{kDa})$ classified into two subclasses according to the level of PTM [116]. Subclass I contains microcin B17, C7, D93, and 25 ( $\mathrm{MW}<5 \mathrm{kDa}$ ), which have undergone extensive backbone PTM, whereas subclass II includes larger $(5-10 \mathrm{kDa})$, slightly post-translationally modified or unmodified peptides [117]. Examples of subclass II include microcin E492, V, L, and H47. Many modes of action for the microcins have been described, reflecting their diverse cellular targets. For example, E492 targets the bacterial membrane via pore formation and membrane potential disruption [118], whereas B17 interferes with replication by targeting the 
DNA gyrase [119]. J25 likely has a dual mechanism of action involving interference with RNA-polymerase [120] and membrane disorganization [121].

Phage tail-like bacteriocins are high molecular weight cylindrical peptides, so named due to their high similarity to the phage tail structure [122,123]. Phage tail-like bacteriocins can be divided into two major class, namely the R-type (related to contractile Myoviridae phage tails) and F-type (related to Siphoviridae phage tails) [122]. The most studied phage tail-like bacteriocins are the R- and F-pyocins from P. aeruginosa [113]. The R-type phage tail-like bacteriocins initially bind to cell surface receptors after which the sheath (a polymer of a single polypeptide) contracts, forcing the internal core into the cell envelope. This process leaves a channel in the cell envelope through which ions flow, decoupling cellular ions gradients and respiration and resulting in rapid cell death [122]. The R-type phage tail-like baceriocins also interfere with oxygen uptake and macromolecule synthesis [124]. While the F-type phage tail-like bacteriocins lack a contractile mechanism, it is thought that a similar channel to the R-types nonetheless forms in the inner membrane, resulting in killing via a similar mechanism [125].

\subsection{Fungal AMPs}

Fungal AMPs can be divided into peptaibols and fungal defensins [126,127]. The peptaibols are mainly derived from the soil fungi Trichoderma [128]. They are short peptides of 5-21 amino acids, contain a high proportion of non-proteinogenic amino acids such as $\alpha$-aminoisobutyric acid (Aib), and typically have an acylated $\mathrm{N}$-terminal residue and an amino alcohol (e.g., phenylalaninol or leucenol) attached to the C-terminal [129]. Their name derives from three of their characteristic components: peptide, Aib, and amino alcohol [130]. The peptaibol database contains 317 molecules (http:/ / peptaibol.cryst.bbk.ac.uk/home.shtml (accessed on 2 October 2020)) [131]. The most widely studied peptaibol is alamethicin, which was isolated from T. viridea and is active against both Gram-positive (E. faecalis, S. hemolyticus, S. aureus, and Streptococcus viridans) and -negative (E. coli, K. pneumoniae, P. vulgaris, and P. aeruginosa) bacteria [132] and fungi [129]. Other peptaibols include trichogin GA IV from T. longibrachiatum, a 10-amino acid, protease-resistant peptide with an $N$-terminal acyl chain, Aib residues, and a Cterminal leucinol [133]; tricholongin B (BI and BII), a group of 19-amino acid, highly hydrophobic peptides from T. longibrachiatum which are active against fungi and Gram-positive bacteria [134]; saturnisporin SA (SAII and SAIV), from T. Saturnisporum, a 20-amino acid peptide active against S. aureus [135]; sillucin, from Rhizomucor pusillis, a 30-amino acid AMP containing four disulfide bridges with activity against Gram-positive bacteria [136,137]. The primary mechanism of action of all peptaibols is similar and primarily involves membrane disruption [138]. Based on chain length, peptaibols are classified into short-chain (5-10 amino acids), medium-chain (11-16 amino acids), and long-chain (17-21 amino acids) peptaibols [138]. Classification based on sequence similarity has also been suggested [139]. Larger peptaibols ( $\geq 15$ amino acids) can form helical structures that oligomerize and form ion channels in the membrane $[139,140]$. The action of shorter peptaibols ( $<15$ amino acids) is more complex, with activity likely resulting from a combination of membrane disruption (e.g., formation of transmembrane channels via helical bundles within the bilayer or by a barrel stave mechanism) and effects on different molecular targets [141,142].

Defensins are short, cysteine-rich peptides that are widely distributed across microorganisms, plants, and animals [143]. The fungal defensins are named defensin-like peptides (DLPs) due to their high sequence and structural similarities [144]. Plectasin, from Pseudoplectania nigrella, was the first characterized fungal defensin and exhibits activity against predominantly Gram-positive bacteria including S. pyogenes, C. jeikeium, C. diphtheriae, and S. aureus $[145,146]$. Plectasin is structurally similar to plant and insect defensins and contains a core structural motif of a cysteine-stabilized $\alpha / \beta$-fold [146]. Whereas many defensins are thought to act via disruption of the microbial cytoplasmic membrane, plectasin acts by binding directly to the bacterial cell-wall precursor lipid II, thereby inhibiting cell wall biosynthesis [145]. Copsin (produced by Coprinopsis cinerea) acts similarly to plectasin and is active against a variety of Gram-positive bacteria including L. monocytogenes, $M$. 
luteus, B. subtilis, and E. faecium [147]. Micasin (from Microsporum canis) has broad-spectrum antibacterial activity including against $P$. aeruginosa and methicillin-resistant $S$. aureus; it possibly acts by affecting protein folding, although further studies are required [148].

\subsection{Plant Derived AMPs}

Cysteine-rich AMPs form part of the plant defense systems. They contain multiple disulfide bridges ( 2 to 6 ) that result in a compact conformation and confer stability against chemical, thermal, and proteolytic degradation [149]. Plant AMPs are classified into various families according to their cysteine motifs, sequence similarity, and arrangement of disulfide bridges. These families (described briefly in Table 1) include $\alpha$-hairpinin, defensins, hevein-like peptides, knottin-type peptides (linear and cycle), lipid transfer proteins, thionins, snakins, and unclassified cysteine-rich AMPs [149,150].

Table 1. Classification of Plant AMPs.

\begin{tabular}{|c|c|c|c|}
\hline Class & Description & Activity & References \\
\hline Thionins & $\begin{array}{l}\text { Cationic peptides of } 45-48 \text { amino acids } \\
\text { containing } 3-4 \text { disulfide bridges }\end{array}$ & Antibacterial, Antifungal & {$[149,151]$} \\
\hline Defensins & $\begin{array}{l}\text { Catoinic peptides of } 45 \text { to } 54 \text { amino } \\
\text { acids containing } 4-5 \text { disulfide bridges }\end{array}$ & Antibacterial, Antifungal & {$[152,153]$} \\
\hline Hevein-like peptides & $\begin{array}{l}\text { Basic peptides of } 29-45 \text { residues } \\
\text { containing } 3-5 \text { disulfide bridges, rich in } \\
\text { glycine and aromatic residues }\end{array}$ & Antifungal & {$[154,155]$} \\
\hline Knottin-typepeptides & $\begin{array}{l}\text { Peptides of } \sim 30 \text { residues, consisting of } \\
\text { conserved cysteine residues and } \\
\text { disulfide bridges }\end{array}$ & Antiviral, Antibacterial & {$[149,156]$} \\
\hline$\alpha$-Hairpinins & $\begin{array}{l}\text { Rich in lysine/arginine, containing a } \\
\text { helix-loop-helix secondary structure }\end{array}$ & $\begin{array}{l}\text { Anti-HIV, Antibacterial, } \\
\text { Antifungal }\end{array}$ & [149,157-159] \\
\hline Lipid Transfer Proteins & $\begin{array}{l}\text { Cationic peptides containing } 70-90 \\
\text { residues that includes } 8 \text { cysteine } \\
\text { residues }\end{array}$ & Antibacterial, Antifungal & {$[149,160,161]$} \\
\hline Snakins & $\begin{array}{l}\text { Catoinic small sized proteins } \\
\text { characterized by } 12 \text { conserved cysteine } \\
\text { residues }\end{array}$ & Antibacterial, Antifungal & {$[162,163]$} \\
\hline Non-Cysteine Rich Peptides & $\begin{array}{l}\text { Containing } 0-1 \text { cysteine residues and } \\
\text { possessing high structural flexibility }\end{array}$ & Antibacterial, Antifungal & {$[149,164,165]$} \\
\hline
\end{tabular}

\subsection{Animal Derived AMPs}

\subsubsection{Invertebrates}

Invertebrates lack an adaptive immune response and synthesize AMPs as an integral component of humoral defense $[166,167]$. Examples of invertebrate AMPs include those found in insects (defensins and cecropins), molluscs and nematodes (defensins), horseshoe crabs (big defensins), invertebrate $\beta$-defensins, and crustaceans (crustins) [168]. They are generally classified based on either ancestral studies or sequence analysis. When based on ancestral studies, defensins are classified into two superfamilies: (i) Cis-defensins, a large family distributed across the fungal, plant, and animal kingdoms, and (ii) Trans-defensins, a small family consisting of invertebrate big defensins and vertebrate defensins [169]. Trans-defensins are further classified into $\alpha$-defensins, $\beta$-defensins, $\theta$-defensins (related to $\alpha$-defensins), and big defensins based on the arrangement of disulfide bridges between six conserved cysteine residues and their overall 3D structure $[169,170]$. When sequence analysis of conserved cysteine patterns is used for classification, invertebrate AMPs can be classified into five groups: (I) arthropod and mollusc-type 6-cysteine defensins (arthropod defensins), (II) mollusc-type 8-cysteine defensins, (III) nematode-type 8-cysteine defensins, (IV) invertebrate big defensins, and (V) invertebrate (putative) $\beta$-defensin-like peptides $[171,172]$. 
Defensins, the major AMPs in invertebrates, are cationic peptides that contain six or eight cysteine residues which form three or four disulfide bridges and constitute the common cysteine-stabilized $\alpha / \beta$ motif [172]. Invertebrate defensins are generally classified into two types according to the number of cysteine residues. The largest group, from arthropods, insects, and mollusks, contains six cysteine residues whereas those in nematodes and mollusks contain eight cysteine residues [171]. They are synthesized as prepropeptides that undergo several proteolytic processing events prior to release as active peptides [173]. Despite sharing no structural or sequence homology to vertebrate defensins, they exhibit a similar mechanism of action to their vertebrate counterparts which involves permeabilizing the cytoplasmic or inner mitochondrial membrane of the target bacteria [174-176]. For example, defensin A and sapecin cause cytoplasmic membrane permeabilization via the formation of voltage-dependent channels and by assuming an oligomeric structure in the membrane, respectively $[174,175,177,178]$.

The invertebrate defensins are structurally and phylogenetically related to the vertebrate $\beta$-defensins. 'Big defensin', initially isolated from the Horseshoe crab (Trachypleus tridentatus), showed anti-fungal and anti-bacterial activity $[179,180]$. Homologous big defensins have subsequently been identified in bivalve mollusks (Bivalvia) and amphioxus (Cephalochordata) [181-183]. Big defensin contains two structural domains: a hydrophobic rich $\mathrm{N}$-terminal domain with activity against Gram-positive bacteria, and a cationic $C$-terminal domain containing six cysteine residues with activity against Gram-negative bacteria [179]. $\beta$-defensin-like peptides have also been found in lobster Panulirus japanicus [184] and P. argus [185], and are likely involved in important biological activities given their sequence and structural similarity to vertebrate defensins. Cecropins are basic peptides (MW, $4 \mathrm{kDa}$ ) synthesized as precursor prepropeptides of 58-64 residues that undergo PTM [186]. Once a threshold concentration has been reached, mature cecropin molecules aggregate on bacterial lipid bilayer membranes causing membrane disruption and subsequent bacterial cell death via a carpet-like model (discussed further in Section 4.2) [187-190]. They are subdivided into six classes, namely A, B, C, D, and E [191,192]. The primary cecropins are classes A, B, and D and are cationic linear AMPs $[193,194]$. Classes C, E, and $\mathrm{F}$ are present in low amounts and are classified as the degradative products of $\mathrm{A}, \mathrm{B}$, and $\mathrm{D}$, respectively (Hultmark et al., 1982). Cecropins are more active against Gram-negative than Gram-positive bacteria [190]. For example, cecropin B possesses 40-fold greater activity against E. coli than S. aureus [195].

Crustins are cationic cysteine-rich peptides found in crustaceans that form a tightly packed structure [196]. The first crustin identified, carcinin, was isolated from the shore crab Carcinus maenas and had activity only against Gram-positive bacteria [197]. Subsequent crustins have been indentified in shrimp, crayfish, lobster, and other brachyuran crabs [198]. They are characterized by an $N$-terminal multi-domain rich in glycine, proline or cysteine, and a $C$-terminal whey acidic protein (WAP) domain with four $C$-terminal disulfide bridges [199]. Crustins can be classified into three types (I-III) based on differences in domain organization between the WAP domain and signal sequence, the latter being a putative sequence of $16-24$ amino acids at the $\mathrm{N}$-terminus that is removed to convert crustins into the active form [198]. Type I crustins are mainly found in lobster, crab, and crayfish [200-202] and contain a cysteine-rich region of variable length between the signal peptide sequence and WAP domain. They are only active against Gram-positive bacteria [197]. Type II crustins contain a signal peptide sequence followed by long glycine-rich and cysteine-rich domains (four cysteine residues) at the $\mathrm{N}$-terminal, and a cysteine-rich WAP domain (eight cysteine residues) at the C-terminal [198]. They can be further classified into type IIa (active against Gram-positive bacteria [203]) and type Ilb (active against both Gram-positive and Gram-negative bacteria [204]). Type III crustins lack glycineand cysteine-rich regions but contain a proline-arginine-rich domain between the signal sequence and WAP domain. Type IV crustins consists of two WAP domains and are known as double WAP domain (DWD) crustins [199]. Type V crustins were originally discovered 
in ants and contain an aromatic amino acid-rich region between the WAP and cysteine-rich domains [205].

\subsubsection{Fish and Amphibian AMPs}

Vertebrates AMPs range in size from 15-200 residues and play an important role in the immediate defense response to microorganisms [206,207] in fish, amphibians, reptiles, birds, and mamalians.

Fish AMPs include cathelicidins, $\beta$-defensins, hepicidins, piscidins, and histonederived peptides [208]. Cathelicidins are cationic AMPs found in secretory granules of immune cells and are activated upon cleavage by elastase and other proteases [209]. The first cathelicidins were isolated from intestinal tissues of Myxine glutinosa (Atlantic hagfish) and were designated hagfish intestinal AMP (HFIAP)-1, -2, and -3 [210]. They act by permeabilizing lipid membranes and possess broad-spectrum antimicrobial activity against a number of Gram-negative and -positive bacteria [211]. A glycine-rich cathelicidin from Atlantic Cod (CodCATH) has activity against Gram-negative bacteria [212], whereas two cathelicidins isolated from Rainbow Trout, rtCATH1 (R146-P181) and rtCATH2 (R143I178), are potentially active against Lactococcus garvieae and other Gram-negative fish pathogens [213]. Another rtCATH1 fragment (R151-V186) is active against $L$. garvieae and Vibrio anguillarum [214].

Fish defensins are classified as $\beta$-defensin-like proteins given that they contain six conserved cysteine motifs [215-220]. They were initially identified in zebrafish, Fugu, and tetraodon using a database mining approach [216] and are active against bacteria [208] and fish-specific viruses [218,221,222]. For example, cod $\beta$-defensin (defb, identified in Atlantic cod, Gadus morhua) is active against the Gram-positive bacteria Planococcus citreus and Micrococcus luteus [223], whereas EcDefensin (from the orange-spotted grouper, Epinephelus coioides) inhibits the replication of to two marine fish viruses (SGIV [a DNA virus] and VNNV [an RNA virus]) [221].

Fish hepcidins are cysteine-rich, iron regulating antimicrobial hormones that share a $\beta$-sheet-composed hairpin structure linked via four disulfide bonds [224] similar to human hepcidin [225]. In fish, hepcidin are classified as HAMP1 and HAMP2 [208]. HAMP1 is found in both actinopterygian and non-actinopterygian fish; however, HAMP2 has only been reported in actinopterygian fish [226-228]. CsHepcidin produced by Cynoglossus semilaevis is active against $V$. anguillarum and Edwardsiella tarda [229], whereas Om-hep1 from Oryzias melastigmus is active against Gram-positive (C. glutamicum and S. aureus) and some Gram-negative (E. coli MC1061, A. hydrophila, and Pseudomonas stutzeri) bacteria, but not the genus Vibrio [230].

Piscidins are linear AMPs with an amphipathic, $\alpha$-helical structure similar to magainins and cecropins [231]. They are classified into seven types (piscidins 1-7) based on their amino acid sequence, length, and biological activity [232]. The piscidin pleurocidin is a highly basic cationic amphipathic peptide with an $\alpha$-helical structure. It was first isolated from winter flounder (Pleuronectes americanus) and is active against a wide variety of Gram-positive and -negative bacteria [232,233].

Amphibians are the largest source of AMPs, with the Antimicrobial Peptide Database (APD, https:/ / aps.unmc.edu / (accessed on 2 October 2020)) [234] containing 1117 entries from frogs and toads. Amphibian AMPs have been well reviewed [235] and include bombinins, buforin, cathelicidin, dermaseptins, esculentins, fallaxin, magainins, maximins, phylloseptins, phylloxin, plasticins, plasturins, pseudins, and ranateurins (Table 2). 
Table 2. Classification of Amphibians AMPs and their activities.

\begin{tabular}{|c|c|c|c|}
\hline Class & Description & Activity & References \\
\hline Bominin & $\begin{array}{l}\text { Glycine-rich peptides with } C \text {-terminal } \\
\text { amidated residues, isolated from skin } \\
\text { secretions of Bombina genus }\end{array}$ & Antibacterial & {$[236,237]$} \\
\hline Buforin & $\begin{array}{l}\text { Cationic peptides rich in arginine and lysine, } \\
\text { DNA-targeting, isolated from the stomach of } \\
\text { Bufo gargarizans }\end{array}$ & Antibacterial, Antifungal & {$[238,239]$} \\
\hline Cathelicidin & $\begin{array}{l}\text { Amphibian cathelicidins possess homology } \\
\text { with mammalian cathelicidins. Over } 20 \\
\text { cathelicidins have been identified }\end{array}$ & Antibacterial & {$[240,241]$} \\
\hline Dermaseptin & $\begin{array}{l}\text { Cationic AMPs with an amphipathic } \\
\text { structure of } 24-34 \text { residues. Dermaseptins } \\
\text { are derived from the skin of the tree frog } \\
\text { Phyllomedusa sauvagii and are involved in } \\
\text { protein synthesis inhibition and induction of } \\
\text { apoptosis }\end{array}$ & $\begin{array}{l}\text { Antiviral, } \\
\text { Antibacterial, } \\
\text { Antifungal, Anticancer }\end{array}$ & [242-244] \\
\hline Esculentin & $\begin{array}{l}\text { Originally found in Rana tigrina (an edible } \\
\text { frog). Characterized by C-terminal disulfide } \\
\text { bond }\end{array}$ & $\begin{array}{l}\text { Antibacterial, } \\
\text { Antifungal }\end{array}$ & {$[245,246]$} \\
\hline Fallaxin & $\begin{array}{l}\text { A 25-residue AMP known as ocellatin-F1; } \\
\text { isolated from Leptodactylus fallax }\end{array}$ & Antibacterial, Leishmanicidal & {$[247,248]$} \\
\hline Maximin & $\begin{array}{l}\text { Derived from toad related species, e.g., } \\
\text { Chinese red belly toad (Bombina maxima) }\end{array}$ & Antibacterial & {$[249,250]$} \\
\hline Magainin & $\begin{array}{l}\text { Alpha-helical peptides isolated from the skin } \\
\text { of X. laevis; interact with membrane } \\
\text { phospholipids leading to disruption of the } \\
\text { ionic gradient }\end{array}$ & $\begin{array}{l}\text { Antibacterial, } \\
\text { Antifungal, } \\
\text { Antitumor }\end{array}$ & [251-253] \\
\hline Plasticin & $\begin{array}{l}\text { Dermaseptin-like peptides with } 23-29 \text { amino } \\
\text { acids; active agasint bacteria via membrane } \\
\text { disruption and pore formation } \\
\text { Isolated from Lithobates Palustris. }\end{array}$ & Antibacterial & {$[254,255]$} \\
\hline Palustrin & $\begin{array}{l}\text { Characterized by the presence of disulfide } \\
\text { bond and the rana box domain }\end{array}$ & Antibacterial & {$[256,257]$} \\
\hline Phylloxin & $\begin{array}{l}\text { Bacteriostatic AMPs; insolated from species } \\
\text { including Phyllobates bicolor. }\end{array}$ & Antibacterial & [258] \\
\hline Phyllospetin & $\begin{array}{l}\text { C-terminal amidated peptides of } 20 \text { amino } \\
\text { acids; isolated from South American tree } \\
\text { frogs; inducing membrane permeabilization } \\
\text { via a carpet-like action }\end{array}$ & $\begin{array}{l}\text { Antibacterial, Antifungal, } \\
\text { Antiparasitic, Anticancer }\end{array}$ & {$[259,260]$} \\
\hline Psuedin & $\begin{array}{l}\text { Isolated from the skin of Psuedis paradoxa; } \\
\text { RNA targeting, ultimately stopping protein } \\
\text { synthesis }\end{array}$ & Antibacterial, Antifungal & {$[261,262]$} \\
\hline Ranateurin & $\begin{array}{l}\text { Derived from the American bullfrog Rana } \\
\text { catesbeiana }\end{array}$ & Antibacterial, Anticancer & [263] \\
\hline Ranalexin & $\begin{array}{l}\text { A C-terminal heptapeptide ringed } 20 \text { amino } \\
\text { acids AMP having one disulfide bond }\end{array}$ & $\begin{array}{l}\text { Antibacterial, Antifungal, } \\
\text { Antiparasitic }\end{array}$ & {$[264,265]$} \\
\hline
\end{tabular}

\subsubsection{Reptile- and Avian-Derived Peptides}

Reptile and avian AMPs are members of the cathelicidin and defensin families [266,267]. Cathelicidins are small-sized AMPs secreted from macrophages and neutrophils upon their activation. Examples of reptile cathelicidins include OH-CATH, a peptide from king cobra contaning 34 amino acids and active against E. cloacae, Enterobacter aerogenes, and P. aeruginosa [268]; cathelicidin BF, a 30-amino acid peptide produced by banded krait and active against $S$. aureus, B. cereus, Salmonella enterica Serovar Typhimurium, E. coli, and P. aeruginosa [269]; omwaprin, a 50-amino acid peptide from the venom of inland taipan (Oxyuranus microlepidotus) and active against Bacillus megaterium and Staphylococcus warneri [270]. We refer readers interested in reptile AMPs to the review by van Hoek [266]. Avian AMPs were first isolated from chicken (Chicken Heterophil Peptides, CHP1 and 2) and turkey (Turkey Heterophil Peptides, THP 1, 2, and 
3) [271]. Cathelicidins from chicken are named fowlicidins and are grouped into three types (fowlicidin-1 to -3) [272]; they are active against Gram-positive S. epidermidis, B. subtilis, and S. aureus, and Gram-negative E. coli, P. aeruginosa, and S. enterica [272-274]. In chickens, chCATH B1, isolated from a specialized organ for hematopoiesis and B cell development (the avian bursa of Fabricius), is a potential antimicrobial against S. aureus, P. aeruginosa, and E. coli [275]. Cathelicidin-like-peptides have also been found in common quail (cathelicidin Cc-CATH1, 2, and 3 from Coturnix coturnix) [276], Japanese quail (Cj-CATH-1, -2, -3, and -B1 from Coturnix japonica) [277], rock pigeon (Cl-CATH2 and 3 from Columba livia) [278], duck (dCATH from Anas platyrhynchos) [279], pheasant (Pc-CATH1, 2, and 3 from Phasianus colchicus) [280], and turkey (CATH2 and 3 from Meleagris gallopavo) [281,282].

The first $\beta$-defensin discovered in reptiles was a 40-residue peptide isolated from leukocytes of the European pond turtle (Emys orbicularis) and named turtle $\beta$-defensin 1 (TBD-1) [283]. TBD-1 is more active against L. monocytogenes and E. coli than MRSA and Candida [283]. Other reptilian AMPs include crotamine [284], pelovaterin [285], and turtle egg-white protein (TEWP) [286]. Avian $\beta$-defensins include AvBD1-14 from chicken [287], ostricacins from ostrich (e.g., OSP-1 to OSP-4) [288], and mallard duck $\beta$-defensins (AvBD2 and AvBD9) [287]. They are grouped according to their sources into heterophil (the predominate granulated leukocyte in the acute inflammatory response) and non-heterophil categories [289]. Heterophil $\beta$-defensins are further divided into two subclasses based on the number of homologous residues. The first subclass shares 22 amino acids and includes THP-1, CHP-1, CHP-2, Gal-1, and Gal-1a, whereas the second subclass shares 17 residues and includes THP-2, Gal-2, and Osp-1 [289]. Non-heterophil $\beta$-defensins include Gal-3, Gallopavin-1 (GPV-1), and sphenicins (Sphe-1 and Sphe-2) [290,291].

\subsubsection{Mammalian-Derived AMPs}

The major mammalian AMPs are members of the cathelicidin and defensins families, although AMPs not belonging to these two families include platelet antimicrobial proteins, hepcidins, and dermcidin [292].

While there is great variety in mature cathelicidin sequences, all mature mammalian cathelicidin peptides are cationic with an amphipathic structure that assumes $\alpha$-helical, $\beta$-hairpin, or elongated conformations [293,294]. LL-37, the most well-studied cathelicidin and the only cathelicidin in humans, has an amphipathic structure which is disordered in aqueous solution but forms an $\alpha$-helix upon membrane interaction [295]. It is activie against a variety of Gram-positive and Gram-negative pathogens and promotes wound healing when applied topically [295-298]. The antibacterial activity of LL-37 is due to either pore-formation or interference with cell wall formation [299-302], whereas its anti-biofilm activity results from a reduction in bacterial cell attachment, the stimulation of twitch motility, and the suppression of biofilm-development genes [298].

Cathelicidin 4 (indolicidin) is a tryptophan- and proline-rich, 13-residue peptide from bovine neutrophils with activity against both Gram-positive and -negative pathogens [303]. It acts via membrane pore formation and inhibition of DNA synthesis [304]. Seven varieties of cathelicidin 4 (buCATH4 A-G) have been described in water buffalo, the most potent being buCATH4C which is active against B. cereus and S. aureus [303].

Protegrins (PG) are cathelicidins from porcine white blood cells (WBCs) that are arginine and cysteine-rich cationic AMPs of 16-18 amino acids with a $\beta$-hairpin structure containing two disulfide bonds [305]. The protegrin family consists of five members (PG15) $[306,307]$. PG1, the most thoroughly investigated protegrin, is active against $E$. coli, $P$. aeruginosa, E. faecalis, and S. aureus (MRSA) [308], while PG4 is active against B. subtilis [309]. Bactenecins are AMPs rich in arginine that have been isolated from bovine, ovine, and caprine neutrophilic granules [310]. Their activity is primarily directed against Gramnegative bacteria and they are cytotoxic for rat embryonic neurons, fetal rat astrocytes, and human glioblastoma cells [311]. Bacterial killing results from membrane permeabilization and blockage of RNA synthesis [312]. Three equine cathelicidins (eCATHs) have been 
described, namely eCATH1-3 [313]; eCATH1 has the highest antimicrobial potency and broadest spectrum of activity, while eCATH-2 shows a more restricted spectrum of activity.

Vertebrate defensins are classified into three sub-families: $\alpha, \beta$, and $\theta$ [314]. All are synthesized as 'prepropeptides', with the mature peptides sharing several common features including a cationic net charge $(+1$ to +11$)$, short polypeptide sequences $(18-45$ amino acids), three intramolecular disulfide bonds, and no glycosyl or acyl side-chain modification [314]; their tertiary structures contain turn-like $\beta$-strands. The $\alpha$-defensins are cationic AMPs of 29-35 amino acids with a secondary structure characterized by three anti-parallel $\beta$-sheets. They are synthesized by promyelocytes, neutrophil precursor cells, and intestinal Paneth cells [315]. Two $\alpha$-defensins from guinea pig neutrophils, GNCP1 and GNCP2 (each with 31 residues and 3 intramolecular disulfide bonds), are active against S. aureus and E. coli [316]. Several rabbit $\alpha$-defensins have been identified, including NP-1 and NP-2, the two most cationic peptides with a broad spectrum of activity against both Gram-positive and -negative bacteria [317]. Human $\alpha$-defensins HNP1-4 are secreted by neutrophils [318,319], whereas HD-5 and HD-6 are secreted by Paneth cells located in the intestinal epithelium [320-322]. HNP1 is the most well-studied $\alpha$-defensin with activity against S. aureus, B. subtilis, S. epidermis, and E. coli [323] resulting from the inhibition of DNA and protein synthesis [324]. $\beta$-defensins are structurally similar to $\alpha$-defensins but differ in cysteine residue and disulfide bond distribution [325]. The first mammalian epithelia-derived $\beta$-defensin, tracheal antimicrobial peptide, was reported from bovine mucosal epithelial cells and showed activity against Gram positive (S. aureus) and Gramnegative (P. aeruginosa, K. pneumoniae, and E. coli) pathogens [326]. Lingual antimicrobial peptide was derived from bovine tongue and has activity against Nocardia farcinia, E. coli, $P$. aeruginosa, S. aureus, C. albicans, and C. tropicalis [327,328]. A 13-membered family (BNBD-1 to -13) of $\beta$-defensins was isolated from bovine neutrophils [329]. Four $\beta$-defensins (HBD-1 to -4 ) have been identified in humans $[325,330]$ and are expressed in a variety of cells and tissues including in the epithelial lining of the respiratory [331], gastrointestinal [332], and urinary tracts [333], as well as the testis [334] and keratinocytes [335]. HBD-1 to -3 have activity against Gram-negative bacteria (e.g., P. aeruginosa, E. coli) and yeasts (e.g., Candida albicans and Malassezia furfur), with HBD-3 also having activity against Gram-positive bacteria (S. pyogens, S. aureus [including MDR S. aureus], and vancomycin-resistant $E$. faecium). Chimeric and synthetic HBD-4 are active against E. coli, B. cepacia, P. aeruginosa, $S$. pneumoniae, S. aureus, and S. carnosus [334]. $\theta$-defensins are expressed in some Old World monkeys and orangutans, but not in New World primates or humans [336]. They are structurally dissimilar to $\alpha$ - and $\beta$-defensins and contain a macrocyclic backbone which is synthesized by the joining of two truncated $\alpha$-defensins [337]. $\theta$-defensins are active against B. anthrax, S. aureus, and C. albicans [338-340].

\section{Structural and Physicochemical Properties of AMPs}

Naturally produced AMPs are 10-100 amino acid residues long, with a majority less than 50 amino acids [341]. The shortest peptides in the Antimicrobial Peptide Database (APD), F3 and Gageotetrin A, consist of only two amino acids [342,343]. AMP length is cirtical for antimicrobial and membrane lytic activity because tendency to form secondary structures such as $\alpha$-helices and $\beta$-sheets, which are essential for antimicrobial activity, reduces as the peptide length decreases [344-346].

Most AMPs are positively charged cationic peptides containing hydrophilic and hydrophobic residues at either end (i.e., amphipathic) [347]. Given that the surface of bacterial membranes are often negatively charged [348], positively charged AMPs initially bind to the membrane surface via electrostatic interactions. Once bound, the hydrophobic ends insert into the lipid bilayer causing membrane disorganisation by inducing toroidal pore (i.e., wormhole), barrel-stave, or the carpet model phenomenon (discussed further in Section 4.2), and, eventually, cell death [349-352]. The most positively charged peptides (net charge of +30) are Oncorhyncin II [353] and Oabac11 [354], with the most negatively charged (net charge -12) being cattle chrombacin [355]. The anionic AMPs likely form 
oligomers in the presence of $\mathrm{Zn}^{2+}$ and $\mathrm{Ca}^{2+}$ ions, enabling them to insert their lipid tails into the membrane [356-358].

AMPs can be classified according to their hydrophobicity, i.e., the proportion of hydrophobic amino acids [359]. Peptides lacking hydrophobic residues generally lack strong attachment to membranes, while those with high hydrophobicity such as gramicidin tend to reside longer in membranes [360]. While adsorption, membrane rupture, and antibacterial activity may occasionally be enhanced by increasing the positive charge on the AMP, under physiological conditions where ionic strength is high, highly charged and hydrophilic peptides lose much of their membrane lysis activity due to electrostatic screening [361]. Such inactivation of AMPs may be prevented by augmenting the hydrophobicity [362].

A majority of AMPs undergo PTMs, which significantly alters their structure. Such modifications enable binding to different targets including plasma membranes, nucleic acids, and proteins and/or allows the AMP to retain activity in a variety of environments [363]. A few AMPs undergo chemical modifications at more than one site. For example, styelin D, a 32-residue AMP from hemocytes of the subtidal ascidian tunicate Styela clava, undergoes extensive PTM. This AMP contains two unique amino acids (dihydroxyarginine and dihydroxylysine) and two unusual amino acids (6-bromotryptophan and 3,4-dihydroxyphenylalanine), and undergoes halogenation of tryptophan at position 2 and hydroxylation at various amino acids (Arg, Lys, Tyr) [364]. These modifications allow styelin $\mathrm{D}$ to retain activity at high salinity or low $\mathrm{pH}$ [364]. Artificially induced modifictaions may also alter key AMP properties. For example, cyclization of melittin resulted in a relatively small decrease in the membrane binding affinity of the cyclic analogue but increased antibacterial activity compared to the linear counterpart [365]. PTM may also be used to inactivate a peptide. For example, peptidyl arginine deiminase (PAD)-mediated citrullination of the human cathelicidin peptide LL-37 reduces its endotoxin neutralizing ability [366], while ADP-ribosylation (which considerably reduces the cationicity of LL-37) and carbamylation markedly reduce its biological activity $[367,368]$.

\subsection{Sequence Based Classification}

The universal classification (UC) system categorizes AMPs into four classes based on covalent bonding patterns, namely UCLL, UCSS, UCSB, UCBB [369]. Developed at a time when the 3D structure of very few AMPs was known, this classification system does not take the 3D structure, source, or activity of AMPs into consideration [369].

\subsubsection{UCLL/Class L}

Class I (UCLL) contains linear AMPs such as LL-37 (Figure 2a) and magainins, which may be chemically modified (e.g., via amidation or glycosylation) at their side-chains or backbones [369]. Class I peptides are further categorized into two sub-classes based on the number of polypeptide chains, with linear single-chain AMPs additionally subcategorized into two families based on chemical modifications, namely UCLL1A unmodified peptide families that are amino acid-rich (e.g., Pro-Arg-rich PR-39), and non-amino acidrich families (e.g., LL-37). The modified AMPs are further classified into two categories depending on the site of chemical modifications, namely UCLL1B the side chain (e.g., Piscidin 4, datucin, MccC7, heliocin) or UCLL1C the backbone (e.g., Aurein 1.2, bombinin $\mathrm{H} 4$, cypemycin (Linaridins), temporin A, and gramicidin). 


\section{searor}

a
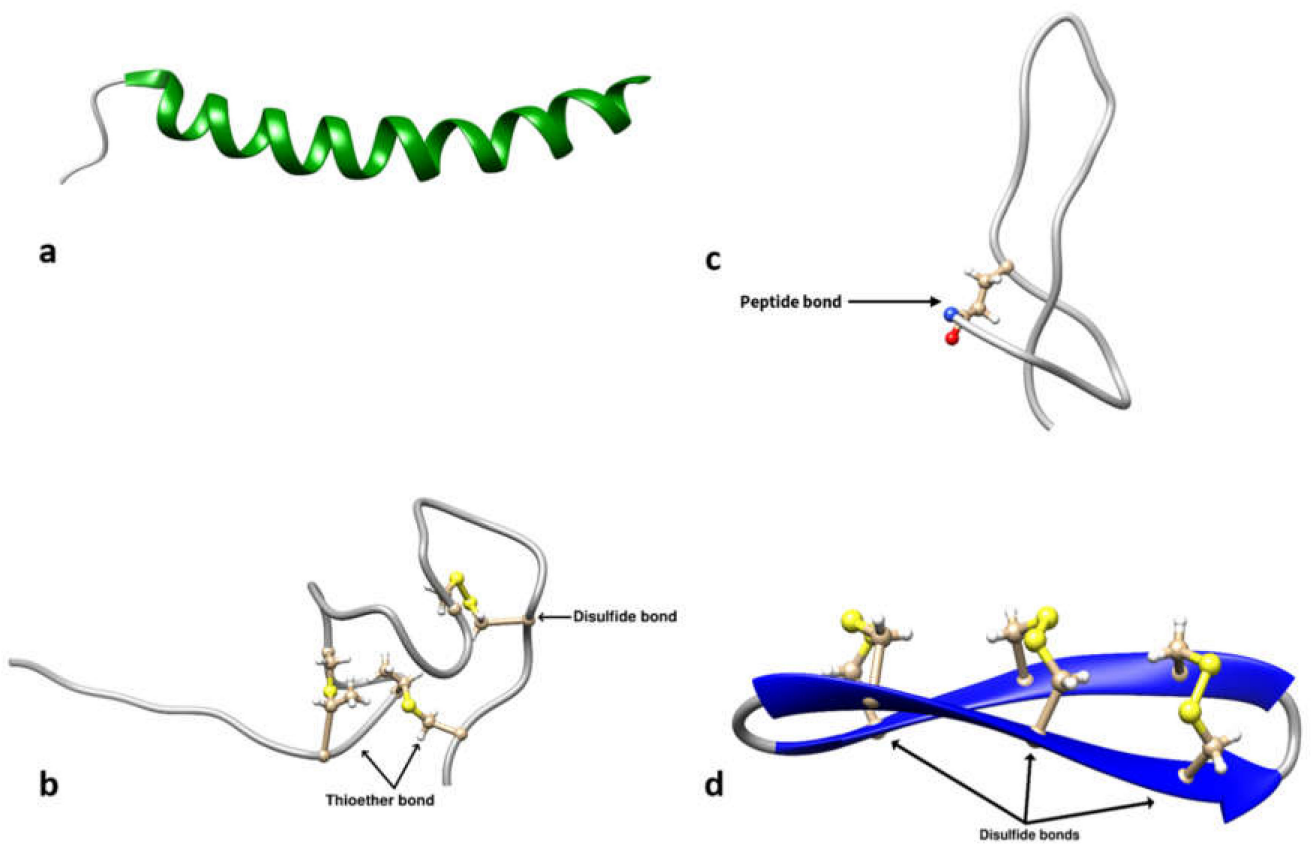

Figure 2. (a) UCLL (LL-37, amino acid sequence LLGDFFRKSKEKIGKEFKRIVQRIKDFLRNLVPRTES, PDB entry: 2K6O). (b) UCSS (bovicin HJ50, amino acid sequence ADRGWIKTLTKDCPNVISSICAGTIITACKNCA, PDB entry: 2M8V). (c) UCSB (microcin J25, amino acid sequence GGAGHVPEYFVGIGTPISFYG, PDB entry: 1Q71). (d) UCBB (rhesus theta defensin-1, amino acid sequence GFCRCLCRRGVCRCICTR, PDB entry: 2LYF). Specifically, dilsufide and thioether bonds in (b,d) are represented by ball-and-stick model, with sulfur, carbon, and hydrogen atoms indicated in yellow, beige, and white, respectively; peptide bond in (c) is represented by ball-and-stick, with nitrogen, oxygen, carbon, and hydrogen atoms indicated in blue, red, beige, and white, respectively.

\subsubsection{UCSS/Class S}

Class II (UCSS) consists of AMPs that form chemical interactions between side chains [369]. These sidechain-sidechain interactions may occur within a single peptide chain or between two different peptide chains. Prominent members of this class include defensins (disulfide-bridged) and lantibiotics (thioether-bonded). Class II AMPs are further classified based on the number of interactions (chemical bonds) and polypeptide chains [369]. Those containing a single chain are the defensins, defensin-like AMPs, and lantibiotics, whereas those containing two chains include centrocin, lacticin-3147, distinctin, halocidin, and dipeptide lantibiotic Smb. Single-chain lantibiotics are further classified into several types based on the number of thioether bonds present. For example, there are two thioether bonds in bovicin HJ50 (Figure 2b), three in lacticin 481, four in cinnamycin, five in nisin and Subtilin, six in Paenicidin A, and seven in Geobacillin I [360,369].

\subsubsection{UCSB/Class $P$}

Class III (UCSB) AMPs contain polypeptide chains with chemical interactions between the side chain of one amino acid and the backbone of another amino acid of the same chain [369]. Examples include lassos, which have a Glu8 or Asp9 residue covalently bonded to the amine terminus [370], and microcin J25, which contains a loop structure due to an interaction between the amine backbone of Gly1 and side chain of Glu8 [371]. Daptomycin also belongs to this class. Class III can be additionally divided based on the bond type formed [369]. For example, microcin J25 contains a CO-NH amide (Figure 2c), fusaricidin A contains a CO-O ester, and thuricidin $\mathrm{CD}$ a $\mathrm{C} \beta-\mathrm{S}-\mathrm{C} \alpha$ linkage.

\subsubsection{UCBB/Class $\mathrm{O}$}

Class IV (UCBB) contains circular AMPs that form a peptide bond between the amino and carboxyl termini of the polypeptide chain [369]. Additional modifications such as 
disulfide bonds may also be present. These AMPs have been isolated from bacteria (enterocin AS-48), plants (cyclotides), and primates ( $\theta$-defensins) (Figure $2 \mathrm{~d}$ ). Class IV AMPs are categorized based on additional linkages and the number of chemical bonds formed within the polypeptide chain [369]. For example, bacterial subtilosin A has a sidechain-backbone interaction $(C \beta-S-C \alpha)$ while plant cyclotides and primate $\theta$ defensins have sidechain-sidechain interactions $(C \beta-S-S-C \beta)[360,369]$.

\subsection{Structure-Based Classification}

Structure-based classification divides AMPs into four distinct groups based on the types of secondary structures present, namely (i) $\alpha$-helical, (ii) $\beta$-sheets (at least two), (iii) $\alpha \beta$, and (iv) non- $\alpha \beta$ [369].

\subsection{1. $\alpha$-helix AMPs}

These are the most studied structures [372], with cecropin, pleurocidin, melittin (Figure 3a), magainin, and moricin being the best described [373]. The $\alpha$-helical AMPs are the most abundant in nature and have been isolated from numerous species including plants, insects, amphibians, fishes, and mammals. Several studies have revealed that the $\alpha$-helical structure of these AMPs is highly reliant on the interaction with the targeted membranes [372,374,375]. This conformational change upon interaction segregates the hydrophilic residues from the hydrophobic residues, with the peptide assuming an amphipathic structure essential for membrane-targeting activity [376]. The structure and activity of amphipathic $\alpha$-helices is well characterized by a typical barrel-stave model that forms a transmembrane pore. The $\alpha$-helices form bundles in the membrane where the hydrophobic region interacts with the membrane lipid core and the hydrophilic region points inward, resulting in a pore [377]. The $\alpha$-helices are often rich in Leu, Ala, Gly, and Lys.

a

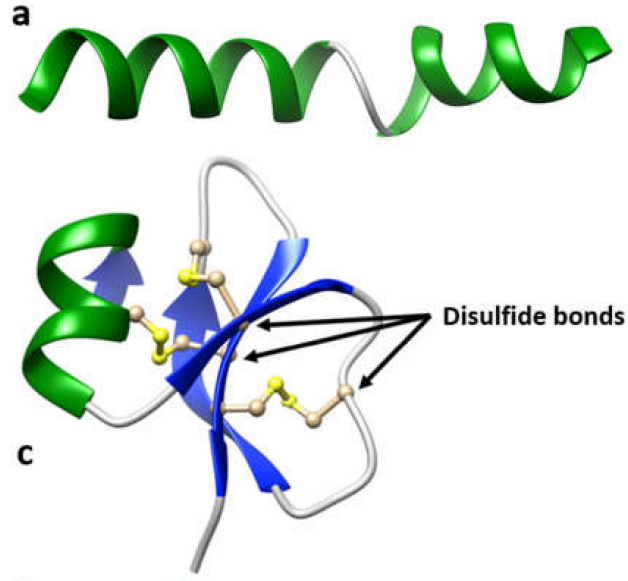

e

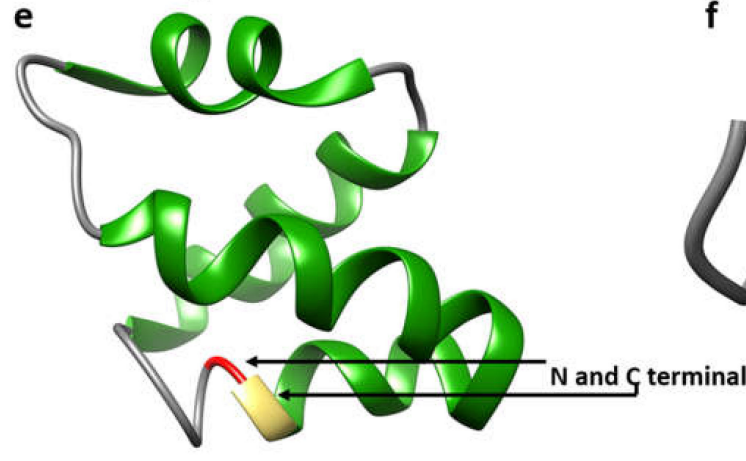

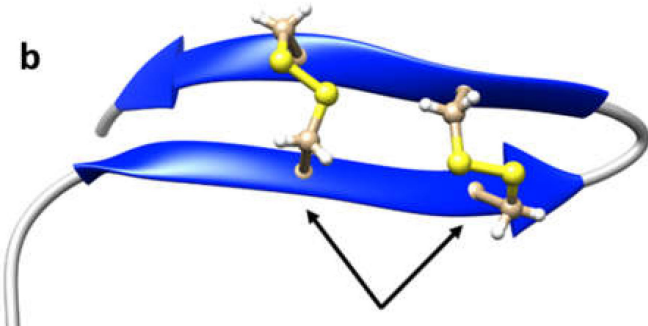

Disulfide bonds

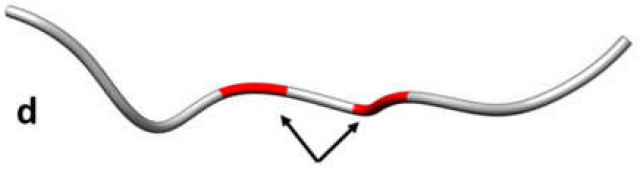

Trp rich region

f

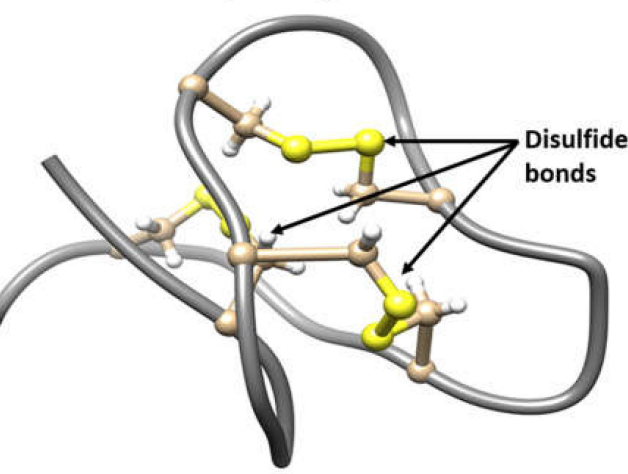

Figure 3. Representative AMPs from five structure-based classes. (a) $\alpha$-helix AMPs (melittin, amino acid sequence GIGAVLKVLTTGLPALISWIKRKRQQ, PDB entry: 2MLT). (b) $\beta$-sheet AMPs (protegrin-1, amino acid sequence 
RGGRLCYCRRRFCVCVGR, PDB entry: 1PG1). (c) $\alpha \beta$-AMPs (hBD2, amino acid sequence GIGDPVTCLKSGAICHPVFCPRRYKQIGTCGLPGTKCCKKP, PDB entry: 1FD4. (d) non- $\alpha \beta$ AMPs (indolicidin, amio acid sequence ILPWKWPWWPWRR, PDB entry: 1G89); Trp-rich regions are indicated in red. (e) Cyclic AMPs with no thioether nor disulfide bonds (carnocyclin A, amino acid sequence LVAYGIAQGTAEKVVSLINAGLTVGSIISILGGVTVGLSGVFTAVKAAIAKQGIKKAIQL, PDB entry: 2KJF). The $N$ - and $C$-terminal linkage is represented by red and beige, respectively. (f) cyclic AMPs with thioether or disulfide bonds (kalata B1, amino acid sequence NGLPVCGETCVGGTCNTPGCTCSWPVCTR, PDB entry: 1K48). Disulfide bonds are represented by ball-and-stick model with sulfur, carbon, and hydrogen atoms indicated in yellow, beige, and white, respectively.

\subsection{2. $\beta$-sheet AMPs}

$\beta$-sheet AMPs consist of at least two $\beta$-strands with many linear structures adopting a $\beta$-hairpin-like conformation [168]. Most members of this family contain conserved cysteine residues that form disulfide bridges critical to their conformation and functions [378]. For example, the disulfide bonds in defensins provide structural stability and reduce proteasemediated degradation [379]. Antimicrobial activity is usually attributed to the cationic residues and hydrophobic side chains exposed on the antiparallel $\beta$-sheets. This class of AMPs include protegrin-1 (PG-1) (Figure 3b) [380], thanatin [381], tachyplesin [382], polyphemusin I [383], and gomesin [384]. Defensins constitute the major group of $\beta$-sheet AMPs and can be further classified into subfamilies based on the location of disulfide bonds. This group of peptides are often rich in Leu, Ala, Gly, and Lys.

\subsection{3. $\alpha \beta$ AMPs}

This class of AMPs contains both $\alpha$-helices and $\beta$-sheets, and strongly target membranes [369]. The most prominent members are the plant and insect defensins that have antifungal activity due to interactions with fungal membrane sphingolipids or microsomal membranes $[385,386]$. The antifungal plant-derived peptide pisum sativum defensin 1 (Psd1) contains a $\beta \alpha \beta \beta$ fold that interferes with cyclin F in Neurospora crassa, thereby affecting the cell cycle [387,388]. RsAFP2, a defensin from Raphanus sativus that interacts with glucosylceramides of yeast and fungi, activates a signaling pathway in C. albicans involved in reactive oxygen species, resulting in cell death [389]. Other class members have alternative targets. Plant defensin Nad1 binds to membrane phosphatidylinositol 4,5bisphophate before interacting with intracellular targets, resulting in the accumulation of reactive oxygen species $[390,391]$. Examples of $\alpha \beta$-AMPs in humans are the beta-defensins hBD1, hBD2 (Figure 3c), and hBD3, which contain an $\alpha \beta \beta \beta$ fold [379].

\subsubsection{Non- $\alpha \beta$ AMPs}

Non- $\alpha \beta$ AMPs, also called extended or loop peptides, lack both $\alpha$-helix and $\beta$ sheet structures and are classified as tryptophan-rich, proline-rich, and glycine-rich peptides [360].

Many tryptophan-rich peptides have an amphipathic conformation. Indolicidin (Figure 3d) has an amphipathic structure that consists of a central tryptophan (Trp)-rich region essential for peptide anchorage. Indolicidin bound to dodecylphosphocholine (DPC) micelles showed an interaction between the Trp6 and Trp9 aromatic rings packed against Pro7 and Pro10, respectively [392,393]. Similarly, tritrpticin in sodium dodecyl sulfate (SDS) micelles contain an amphipathic turn that is clustered with three tryptophan residues [394]. In lactoferrin $B_{2}$, the Trp-rich regions form a non- $\alpha \beta$ conformation with a deformed backbone upon interacting with SDS micelles [395].

The proline-rich peptides are 15-39 residues long [396] and act on intracellular targets $[397,398]$. Recent studies have shown that these peptides adopt a non- $\alpha \beta$ structure that blocks the ribosomal tunnel, thereby preventing aminoacyl tRNA entry into the Asite [399]. Glycine-rich peptides are found in a variety of insect species and typically have a molecular weight ranging from 8 (holotricin) to 30 (sarcotoxin II) kDa [373]. KAMP-19, a glycine-rich peptide from the human eye, possesses a non- $\alpha \beta$ structure that deforms bacterial cell envelopes and induces pore formation [400]. 


\subsubsection{Cyclic and Unusual or Complex AMPs}

Based on the special structural features discussed in Section 3.1 (UCBB/class O) [369], these peptides can be grouped as a fifth class of AMPs [401]. Furthermore, this group can be subclassified based on cyclic topology (either head-to-tail or head-to-side-chain) and crosslinks (e.g., thioether or disulfide bonds) [401]. Cyclic bacteriocins (MW $\sim 6 \mathrm{kDa}$ ) are a group of ribosomally synthesized peptides that are characterized by their $\mathrm{N}$ - to $C$-terminal covalent linkage and lack of additional linkages [402]. For example, carnocyclin A isolated from Carnobacterium maltaromaticum UAL307 and enterocin NKR-5-3B isolated from Enterococcus faecium NKR-5-3 consist of four $\alpha$-helices and have their $N$-terminal linked to the $C$-terminal. In carnocyclin $\mathrm{A}$, the $\mathrm{N}$-terminal Leu at postion 1 is linked to C-terminal Leu at position 60 (Figure 3e), whereas, in enterocin NKR-5-3B, the $\mathrm{N}$-terminal Leu at position 1 is linked to the $C$-terminal Trp at position 64. [403,404]. Other backbonecyclized peptides consist of additional intramolecular thioether and disulfide bonds to stabilize structures. For example, mammalian $\theta$-defensin RTD-1 (Figure 2d) and plant cyclotide Kalata B1 (Figure 3f) are cyclic AMPs containing three disulfide linkages that form a cysteine-knotted framework responsible for conferring significant structural stability to the peptides as compared to linear peptides [401,405,406]. The anti-HIV activity of Kalata B1 is due to an intact cyclic backbone [407]. The cysteine knot is a structural motif forming an embedded ring by three disulfide bonds in which the connecting backbone segments of two disulfide bonds are threaded by a third disulfide bond [408]. This cysteine knot framework can tolerate a wide range of amino acid substitutions and has shown great promise as a scaffold in drug design and protein engineering [405,408]. For example, circulin A and B are macrocyclic cylotides belonging to the bracelet sub-family. The disulfide bond order for circulin A and B is Cys1-Cys17, Cys5-Cys19, and Cys10-Cys24; this arrangement forms a compact structure and fold that is stabilized by an extensive network of hydrogen bonds [409,410]. They exhibit anti-viral activity [411] and can be considered as potential anti-HIV drugs [115]. Tachystatin B is an antimicrobial peptide with three disulfide bonds between Cys4-Cys20, Cys11-Cys25, and Cys19-Cys37. The Cys19-Cys37 disulfide bond traverses through the closed ring formed by the two other disulfide bonds and two segments of the backbone (Cys4-Cys11 and Cys20-Cys25), forming an inhibitory cysteine-knot motif that is considered essential for antimicrobial activity [412]. Subtilosin A is a prominent example of unusual cyclic AMP as it has an amide bond between the $\mathrm{N}$ and C-termini and three cross-links between the sulfurs of Cys13, Cys7, and Cys4 and the $\alpha$-positions of Phe22, Thr28, and Phe31, respectively [413]. A detailed review on the knot motif in cyclic AMPs can be found elsewhere [408].

\section{Diverse Activities and Modes of Action}

AMPs are characterized based on their target organisms and mechanisms of action.

\subsection{Antiviral AMPs}

Antiviral AMPs possess diverse mechanisms of action against both RNA and DNA viruses and can be categorized into the following types based on their mode of action: (i) viral membrane targeting AMPs (e.g., indolicidin, human $\alpha$-defensin 1 ) that eliminate viruses by incorporating themselves into the viral envelope, thereby creating membrane instability and rendering the virus incapable of infecting the host cell [414,415]; (ii) viral adsorption-targeting antiviral AMPs that act by binding to specific viral receptors on target cells, thereby inhibiting viral binding and subsequent entry [416]. For example, defensins interact with herpes simplex virus (HSV) glycoproteins to prevent viral attachment to host receptors [417]. Heparan sulfate is a well-studied example of a negatively charged host cell surface receptor required for HSV entry. Lactoferricin, derived from the cleavage of lactoferrin, inhibits herpes infection by occupying heparan sulfate receptors as well as viral particle receptors, thereby blocking virus adsorption and entry [418-420]. (iii) AMPs targeting intracellular components; for example, NP-1, an alpha-defensin from rabbit neutrophils, inhibits Herpes simplex virus type 2 (HSV-2) by blocking viron protein VP16, 
which is essential for viral translocation into the nucleus [421,422]. Melittin and Cercopin A are insect-derived AMPs that exhibit anti-HIV1 (type 1 human immunodeficiency virus) activity by interfering with viral transcription [423]. Cecropin A can also inhibit the Junin virus (JUNV) by targeting viral nucleocapsid $N$-protein biosynthesis [424]. Red fluorescent proteins (RFP) from Bombyx mori (Silkworm) can disrupt viral nucleocapsids, thereby inhibiting replication [425-427]. L4-1, a peptide isolated from silkworm faeces, produces reactive oxygen species in visible light that damage viral proteins, conferring marked antiviral activity against enveloped viruses (e.g., HJV [Sendai virus], HSV1, and HIV1 [human immunodeficiency virus type 1]) but not non-enveloped viruses [428]. Indolicidin, in addition to the mechanism of action mentioned above (Section 2.5.4), inhibits arenavirus replication by interfering with late-phase events such as viral morphogenesis and the inhibition of viral release from the host cell [424].

\subsection{Antibacterial AMPs}

Antibacterial AMPs are the most thoroughly investigated AMP class, with a majority being cationic and amphipathic. They interact with anionic bacterial membranes, causing disruption to the lipid bilayer $[429,430]$. Certain anionic peptides also have antibacterial activity that includes surfactant-associated anionic peptides (SAAP), frog maximin-H5, and human dermcidin [431,432].

Certain lipopetides (e.g., polymyxins B and E, daptomycin) and glycopeptides (e.g., vancomycin, teicoplanin, telavancin, dalbavancin, and oritavancin) are currently available in the clinic. Both polymyxins have similar in vitro potencies and a spectrum of activity against primarily Gram-negative pathogens, including many responsible for MDR nosocomial infections [433]. Daptomycin is a 13-residue cyclic lipopeptide with a hydrophilic core. It was isolated from Streptomyces roseosporus and is used for the treatment of recalcitrant Gram-positive infections [434]. The glycopeptides have a broad antibacterial spectrum against Gram-positive bacteria [435]. Bacterial killing by the glycopeptides is due to their binding to cell wall precursors rather than acting directly on an enzyme active site. For example, the cyclic heptapeptide core of vancomycin forms a unique binding pocket for the $\mathrm{D}$-alanine (D-Ala) dipeptide D-Ala-D-Ala located at the $C$-terminus of the pentapeptide precursor, inhibiting peptidoglycan chain formation and cross-linking [436,437].

Antibacterial AMPs are subcategorized into two types based on their mechanisms of action: (i) membrane disrupting and (ii) non-membrane targeting peptides [438]. However, some AMPs may act via both mechanisms.

\subsubsection{Membrane Targeting AMPs}

Many antibacterial AMPs target bacterial cell membranes via initial electrostatic interactions between positively charged peptide molecules and the negatively charged cell surface, followed by hydrophobic interactions between the peptide amphipathic domain and the membrane phospholipids [375]. The modes of action proposed for subsequent pore formation are the barrel-stave [439], carpet-like [440], toroidal pore (Figure 4) [441], aggregated channel [393], and clustering of anionic lipids models [442]. Some AMPs act via more than one mechanism. 


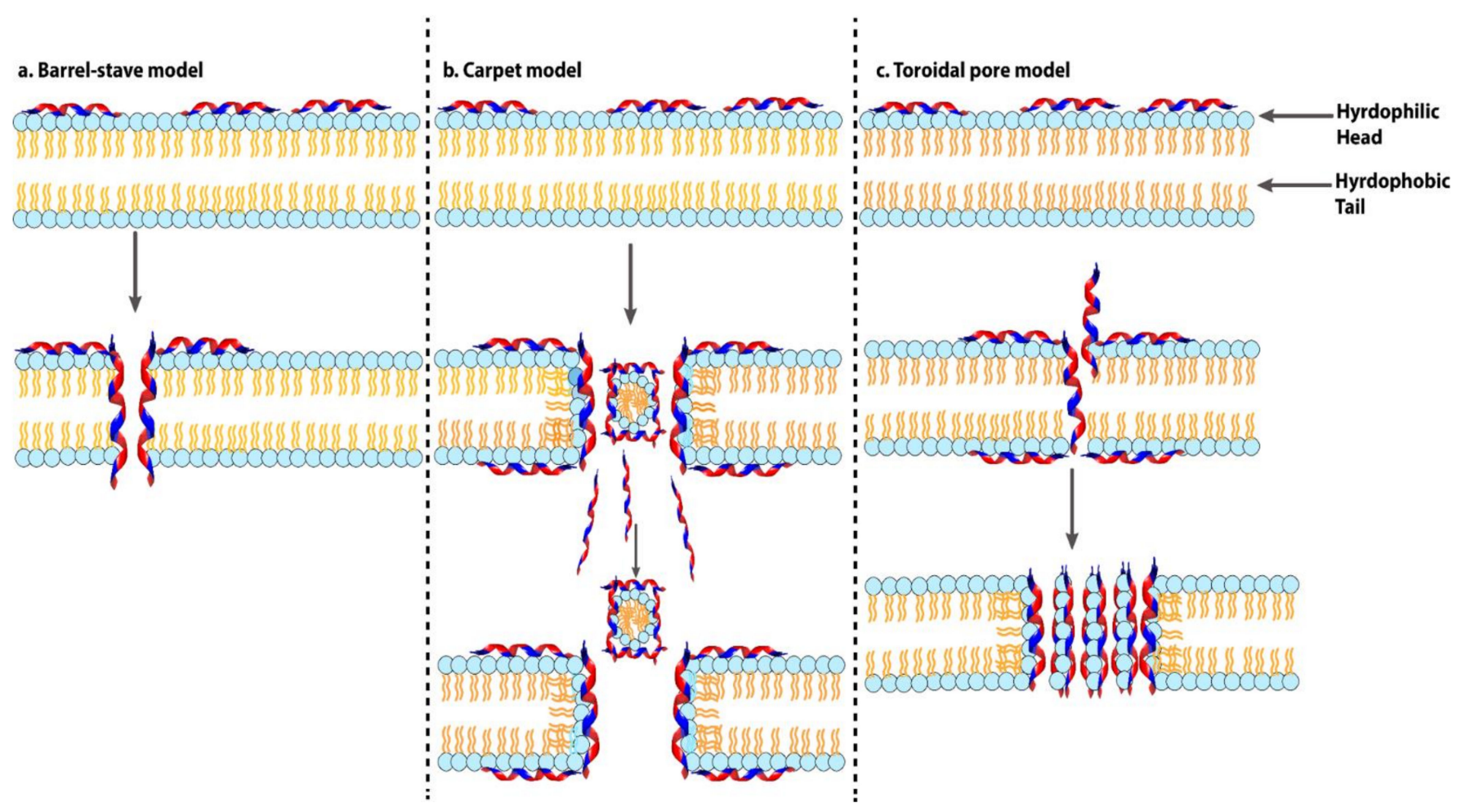

Figure 4. (a) Proposed barrel-stave model [443], (b) carpet model [444], and (c) toroidal pore model [445]. The hydrophilic and hydrophobic regions of the AMPs are represented in blue and red, respectively. The hydrophilic head and hydrophobic tail are represented in cyan and orange, respectively.

The barrel-stave mechanism is characterized by the vertical aggregation of helices into the lipid bilayer. The transmembrane peptides bundle similarly to the staves of a barrel, with their hydrophobic face aligned with the central lipid region of the lipid bilayer while the hydrophilic peptide constituents form the inner water-filled pore region [446]. The stable channels (barrel-like pores) formed in the cell membrane result in cytoplasmic outflow and, in severe cases, membrane collapse and ultimately cell death [447]. This mechanism is exhibited by pardaxin [448], alamethicin [449], ceratotoxin [450], $\delta$-endotoxin [451], peptaibols such as antiamoebin I (AamI) [452] and Class II bacteriocins [453], some magainins, PGLa [454], and MSI78 [455].

In the toroidal pore model, the peptides inserted into the membrane cause a continuous bending of the lipid monolayer from top to bottom [449]. The central water core is lined with the embedded peptides and lipid head groups. During the formation of a toroidal pore, the polar regions of the peptides align with the lipid polar head groups. The toroidal pore mechanism is similar to the barrel-stave model but differs in the fact that peptides are aligned with the lipid head groups even when they are inserted perpendicularly into the lipid bilayer [446], the pores formed are transient, and the structures formed are less stable than barrel-stave formations [456]. Examples of peptides that act via this mechanism include arenicin, magainin 2, and lacticin Q [457-459]. Melittin commonly acts via toroidal pore formation, although barrel-stave or detergent mechanisms have also been suggested $[449,460,461]$. AMPs maculatin1.1, protegrin-1, tritrpticin, and pleurocidin act by forming ion channels via the toroidal pore model whereby AMPs bind to cell membrane surface phospholipids, form peptide-lipid polymers, and eventually enter the cell [462-464].

The carpet or detergent-like model was first described for dermaseptin S [351]. It hypothesizes that the peptides initially aggregate on the membrane in monomeric or oligomeric form (covering the membrane like a carpet), with the hydrophobic regions subsequently interacting with the cell membrane and the hydrophilic ends facing the 
aqueous solution. When a concentration threshold is reached, aggregation of the peptides induces membrane permeation with subsequent membrane disruption [430]. Other examples of peptides that likely act via the carpet-like model are cecropins [465], indolicidin [393,466,467], aurein 1.2 [468], caerin 1.1 [469], and trichogin GA IV [470].

Anionic lipid clustering activity involves the preferential interaction of cationic AMPs with anionic charged lipids, causing lateral segregation of these lipids from zwitterionic ones, resulting in the formation of phase boundary defects between lipid domains [442]. Such activity is exhibited by MSI-103, PGLa, Magainin, KIGAKI, MAP, and penetratin [442].

\subsubsection{Non-Membrane Targeting/Intracellular AMPs}

Some AMPs can kill bacteria without affecting membrane stability. These AMPs directly penetrate bacterial cells and interfere with essential cellular activities including DNA replication, transcription, translation, protein folding, and cell division [471,472]. Nucleic acid-targeting AMPs include the buforins I and II [473,474], which have been shown to penetrate the cell membrane of E. coli without permeabilization [475], subsequently binding to DNA and RNA [473-475]. Parasin I and hipposin from catfish skin mucus exert their antimicrobial activity via a similar mechanism to buforins $[476,477]$. At high concentrations, indolicidin, a Trp/Pro-rich AMP of 13 residues, induces membrane permeabilization, which allows peptides to continuously enter the cytoplasm where they interfere with DNA synthesis [478]. Specifically, indolicidin targets the abasic site of DNA causing crosslinks with single or double-stranded DNA, as well as inhibiting DNA topoisomerase I [467]. Other DNA-targeting AMPs include ostricacin I (OSP1) and ostracacin 2 (OSP2), oabac 5mini, and microcin B17 (the latter blocking DNA gyrase) $[479,480]$. PR39 acts by secondary DNA synthesis inhibition by targeting DNA replication-associated proteins [481]. Cell division-blocking AMPs act via inhibiting DNA replication and DNA damage responses (e.g., the SOS response), thereby blocking the cell cycle or inducing failure of chromosome separation [482]. Microcin J25 arrests cell division in E. coli by targeting RNA polymerase (RNAP) [483]. Human $\alpha$-defensin 5 interferes with cell division in Gram-negative bacteria by bleb formation, cellular elongation, and clumping [484].

Protein synthesis-targeting AMPs exert their antibacterial effect by blocking protein biosynthesis either through effects on transcription, translation, or protein assembly [485]. For example, Bac7 (1-35) inhibits translation by interfering with ribosomes (Figure 3) [398]. Pleurocidin, in addition to ion channels formation via the toroidal pore model, likely inhibits protein biosynthesis in E. coli [486]. The hybrid peptide DM3 exhibited broad spectrum, rapid antibacterial killing via the disruption of DNA replication, transcription, ribosome assembly, and amino acid biosynthesis [487]. Apidaecin has recently been shown to competitively bind with release factors on the A-site of ribosomes, inhibiting the termination step of translation [488]. Human neutrophil peptide defensin (HNP)-1 sequentially induces membrane permeabilization of the outer and inner membranes in E. coli as well as inhibition of DNA replication, transcription, and protein synthesis [324]. Lactoferrin B, PR39, P-Der, and Bac7, when incubated with E. coli, demonstrated inhibitory activity on arginine decarboxylase and various other proteins [489]. Defensins and dermaseptins also arrest protein synthesis [490].

Protein folding inhibition occurs with some insect-derived, proline-rich peptides known to inhibit bacterial DNA replication by interfering with protein folding. Pyrrhocoricin can block the molecular chaperones DnaK and GroEL, and also reduce DnaK ATPase activity via competitive inhibition [491,492]; drosocin (DnaK and GroEF) [491] and apidaecin (DnaK) [493] exert similar inhibition. Similarly, Bac7 (1-35) potentially binds DnaK, blocking the protein folding of molecular chaperones (DnaK-DnaJ, GrpE-ATP) in a dose-dependent manner [494]. Oncocin, another proline-rich peptide of 19 residues, exerts activity against Gram-negative pathogens such as E. coli, P. aeruginosa, and A. baumannii by freely penetrating (without lysing) the cell membrane and subsequently binding with DnaK, thereby interfering with protein folding [495,496]. 
Other AMPs act via inhibition of protease activity, thereby interfering with critical cellular metabolism. For example, eNAP-2 from equine leukocytes exerts antibacterial activity against $E$. coli, P. aeruginosa, S. zooepidermicus, and K. pneumoniae by preferentially binding bacterial serine protease, proteinase $\mathrm{K}$, or subtilisin A to form non-covalent complexes [497]. Ixodidin is a cysteine-rich, 65-residue AMP from tick hematocytes that inhibits the cellular metabolism by blocking elastase and chymotrypsin [498]. Histatin 5, from the salivary secretions of human submandibular and parotid glands, is a histidine-rich, cationic AMP of the histatin family [499]. Against $S$. mutans, a major cause of dental caries [500], histatin 5 blocks host as well as bacterial proteases, preferentially binding to trypsin-like proteases [501].

Cell wall-inhibiting AMPs target lipid II, an essential constituent of peptidoglycan. Nisin, a lantibiotic and the best-characterized AMP of this class, possesses lipid II sequestering activity and inhibits the transglycosylation step in cell wall biogenesis [69]. Mersacidin, a globular lantibiotic possessing four thioether bridges, binds to lipid II and inhibits transglycosylation in a similar manner to nisin (Figure 3) [502]. Similar activity has been observed for lacticin 481 and cinnamycin (both lantibiotics) [503], HBD3 and HNP1 [504,505], and the novel fungal AMP copsin [147].

\subsection{Antifungal AMPs}

Antifungal peptides have been isolated from a number of species of archaea, bacteria, plants, and animals [506]. The fungal cell wall is mainly composed of chitin [507]. Antifungal AMPs possess similar mechanisms of action to antibacterial AMPs, namely the (i) barrelstave (e.g., observed with Amphotericin B which binds to membrane ergosterol) [508,509], (ii) carpet-like (e.g., Dermaseptin, disrupting microbial cell membranes) [510,511], and (iii) toroidal pore (e.g., LL37 interacts with the cell wall carbohydrates of candida and protegrin-1) [512] models. Other mechanisms of action include (iv) inhibition of 1,3- $\beta$ glucan biosynthesis (e.g., echinocandins, pneumocandins, aculeacins), (v) inhibition of chitin biosynthesis (e.g., aureobasidins), and (vi) interference with other critical intracellular targets such as DNA-targeting actinomycins that intercalates DNA and buforins that target the DNA. Examples of this latter group include the tridecapeptide indolicidin, which interferes with DNA processing enzymes and repair mechanisms, and VL-2397 (from Acremonium persicinum), which acts as an iron-chelating siderophore that causes hyphal elongation arrest [242,513]. The structures of most antifungal AMPs are currently not well determined. However, upon interacting with membranes, some naturally occurring AFPs assume $\alpha$-helical, $\beta$-sheet or hairpin (with two cysteine residues) structures, or mixed $\alpha$-helix/ $\beta$-sheet conformations. For further information on antifungal AMPs, we refer interested readers to the reviews by Fernández de Ullivarri et al. and De Cesare et al. [506,513].

\section{AMP Databases}

Leveraged by the progress of systems pharmacology, chemical biology, and computational biology, the number of naturally produced and chemically synthesized AMPs in databases has rapidly increased in recent years. Of the AMPs catalogued, antibacterial peptides represent the largest group (Figure 5). Here, we summarize the major regularly curated databases and their associated unique computational tools for AMP discovery and engineering. Some important prediction functionality tools found in many of these databases are briefly described separately in Section 6. 


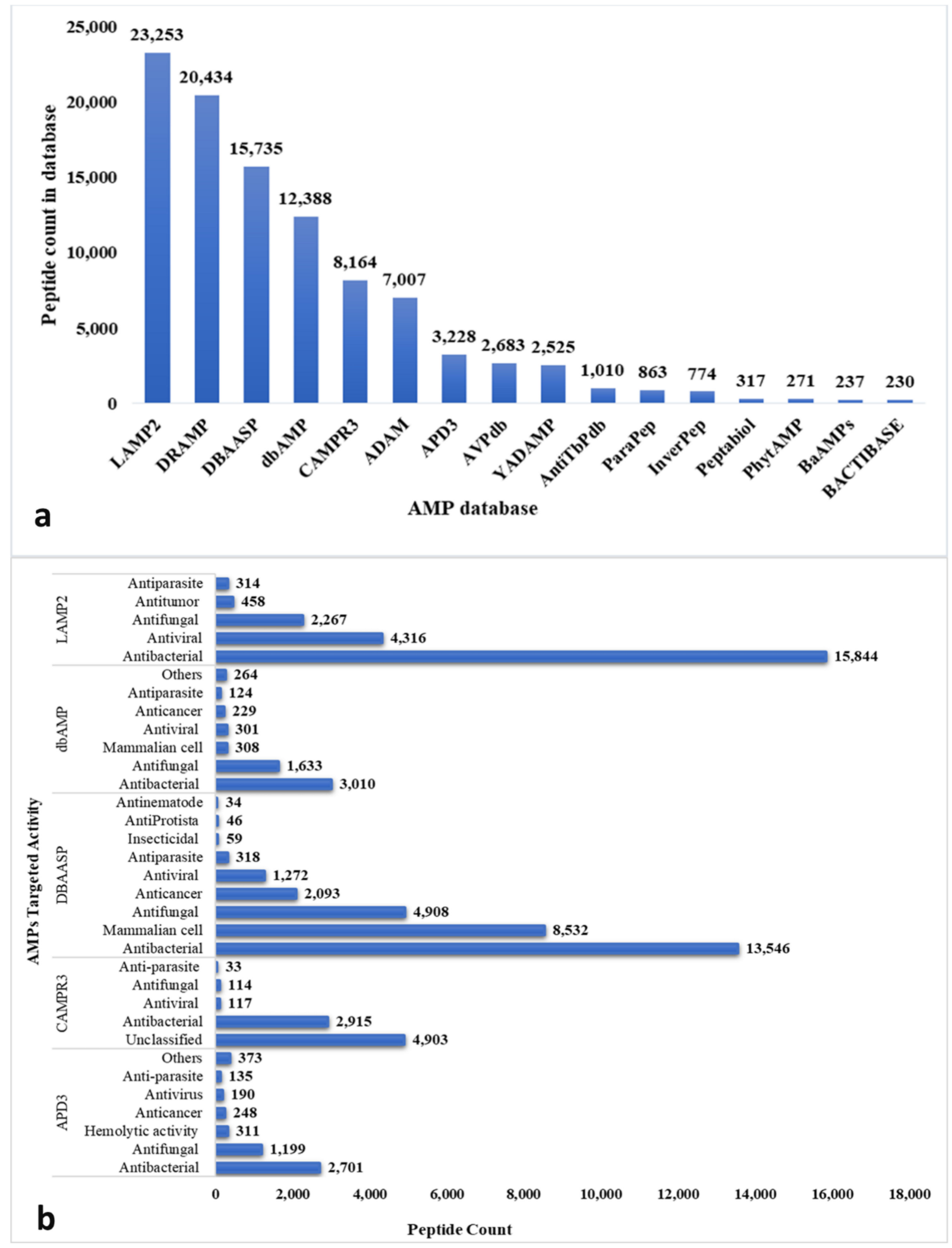

Figure 5. (a) The total number of AMPs contained in a variety of databases and (b) breakdown of AMPs by targeted activity in five representative databases. 


\subsection{APD3}

The Antimicrobial Peptide Database (APD3; available at https://aps.unmc.edu/) is one of the largest databases [234] (last accessed on 2 October 2020). It has catalogued 3250 AMPs, including 2409 from animals, 360 from plants, and 365 from bacteria.

The APD3 provides searchable annotations including source organism, peptide sequence, and PTM (24 chemical modifications are included) (Wang, 2015). Amidation was the most common PTM, followed by Rana Box (via a single S-S bond) and backbone cyclization. The AMP binding targets interface allows searching for the determined mode of action of an AMP, with 10 modes of actions incorporated. Peptide binding to membrane targets is the dominant mode followed by LPS and sugar/carbohydrates targeting. APD3 provides extensive structural classification of AMPs (Figure 6), with the 3D annotated structures deposited in the Protein Data Bank database (PDB) [514]. The structure-determining methods include nuclear magnetic resonance (NMR, 385 structures), circular dichroism (CD, 248 structures), and X-ray crystallography (58 structures). Users can search for AMPs according to the $3 \mathrm{D}$ or covalently bonded structures.

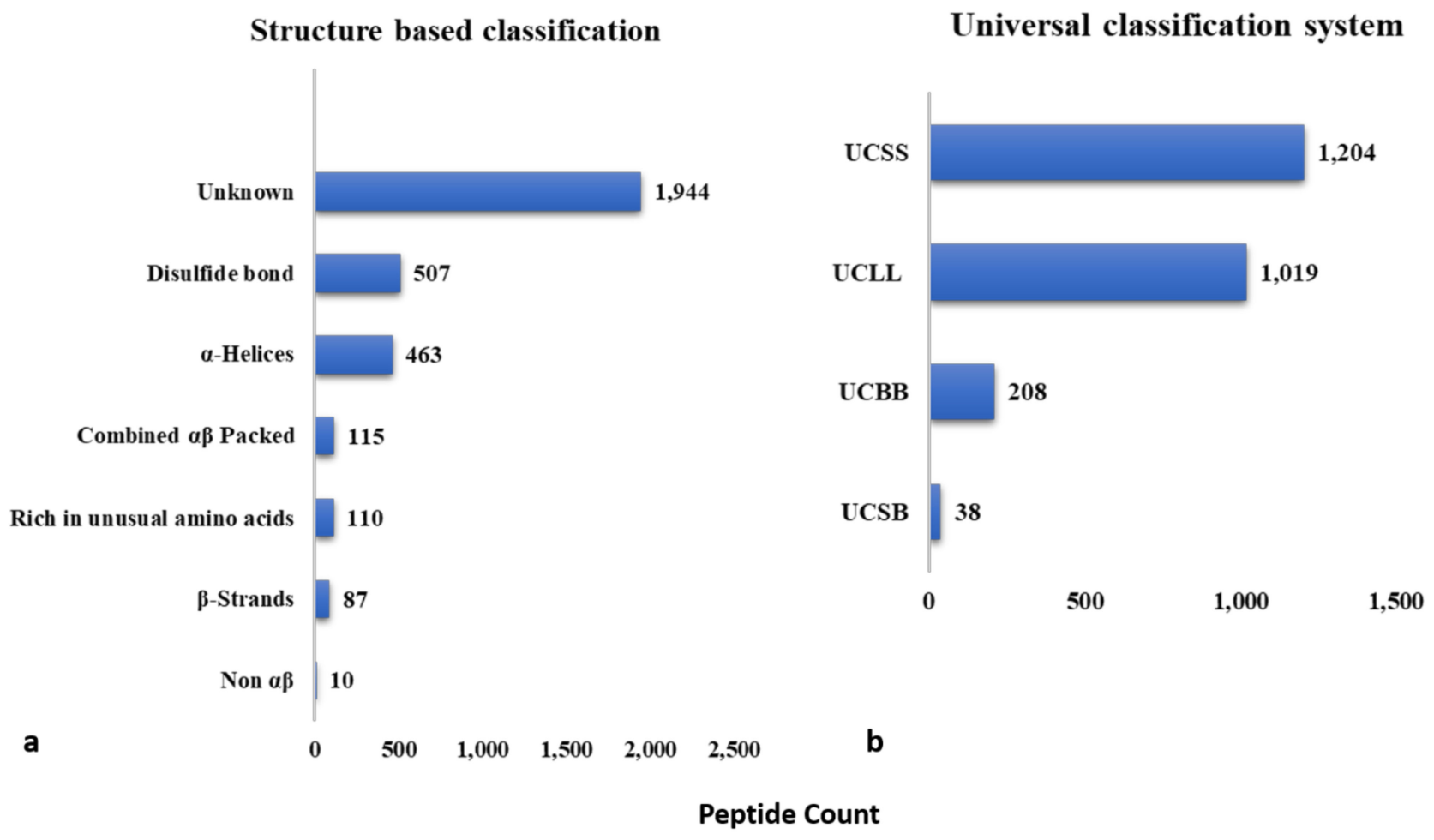

Figure 6. (a) Number of AMP 3D structures and (b) the AMP universal classification system. The x-axis represents the peptide count and, the y-aixs, the strucutre and class of AMPs.

The APD3 database also provides 21 useful tools to predict, modify, and carry out extensive analyses of peptides. Tools include a prediction interface to analyse the potential of a given amino acid sequence to form an AMP. The submitted query additionally returns information such as the amino acid percentage and composition, hydrophobicity content, total net charge, molecular weight, chemical formula, grand average of hydropathicity index (GRAVY, representing the hydrophobicity of a peptide), and Boman index (BI, estimating the protein-binding potential), along with structural information based on the amino acid composition. The peptide improvement tool can be used to increase the potency of peptides. The APD3 is updated frequently, with the latest news and facts provided in the What's New interface. 


\section{2. $C A M P_{R 3}$}

The Collection of Anti-Microbial Peptides database (CAMP R3$_{3}$; available at http:// www.camp3.bicnirrh.res.in (accessed on 2 October 2020)) was developed to promote AMP family-based studies. The database is divided into four main sections, namely (i) sequences (currently 8164 AMP sequences), (ii) structures (757 structures), (iii) patents (2083 patents), and (iv) signatures (36 patterns and 78 Hidden Markov Models (HMMs)). The CAMP ${ }_{\mathrm{R} 3}$ database has classified the collected AMPs into 45 different families based on signatures acquired from HMMs and patterns. Nine different tools are incorporated into the database, most notably (i) AMP Prediction tools for predicting AMPs from amino acid sequences, detecting antimicrobial regions in peptides, and rational design/improvement of AMPs; (ii) CAMPSign feature searches for peptide patterns related to 45 families present in the database; (iii) Vector Alignment Search Tool (VAST) to identify distant homologs based on 3D geometrical criteria; (iv) PRATT for identifying conserved patterns in sets of protein sequences; (v) ScanProsite to search input sequences against Prositemotif; (vi) Pattern Hit Initiated (PHI) BLAST for pattern searches in protein sequences; (vii) JackHmmer for distant homology detection.

\section{3. $d b A M P$}

The dbAMP (available at http:/ / csb.cse.yzu.edu.tw/dbAMP/ (accessed on 2 October 2020)) is an integrated database that collects AMPs from public databases and the literature [515]. Currently, it consists of 12,389 AMPs of which 4270 have been validated and 8118 predicted. Specific AMPs can be retrieved by AMP ID or specific amino acid sequences. Functional type icons are provided to narrow down the search options. The dbAMP provides a unique tool to mine AMP cryptic regions from transcriptomics or proteomics data. Specifically, next generation sequencing (NGS) detection enables the user to detect critical regions of antimicrobial potency from the metatranscriptomics analysis of transcriptomics or proteomics data.

\subsection{DBAASP}

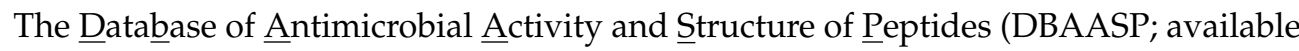
at https: / / dbaasp.org (accessed on 2 October 2020)) is a manually curated database that currently contains 17,532 entries [516]. A unique feature of the database is the molecular dynamics (MD) simulation models with trajectory files and self-consistency data for a large number of peptides. Currently, there are $5618 \mathrm{MD}$ models in the database. These data can be used to better understand structure-activity relationships for rational peptide design. The property calculator tool enables evaluation of an AMPs physicochemical properties and provides six hydrophobicity scales based on the literature [359,517-521].

\subsection{LAMP2}

The Linking Anti-Microbial Peptides database (LAMP; available at http:/ / biotechlab. fudan.edu.cn/database/lamp/index.php (accessed on 2 October 2020)) is an online repository for the discovery and design of AMPs [522]. The database contains 23,253 unique AMP sequences including 7824 natural and 15,429 synthetic AMPs of length shorter than 100 residues.

\section{Prediction Functionality in AMP Databases}

The post-genomic era has boosted AMP discovery and design. Sequence alignment and pattern matching have been intensively employed for the identification of unannotated AMPs. Recently, the explosive growth of sequencing data has stimulated the application of powerful machine learning algorithms in biomedical areas, including genomic mining and the design of AMPs [523]. Many AMP prediction tools have been developed and widely used, including FASTA [524], BLAST [525], HMM [526], REGEX [527], molecular dynamics simulations, and machine learning algorithms. Here, we summarize several major approaches for AMP prediction, namely sequence alignment, pattern-matching, 
molecular dynamics simulations, and machine learning algorithms (examples of the latter include support vector machine, artificial neural networks, and random forest).

\subsection{Sequence Alignment}

Sequence alignment is a method widely employed to determine homology in DNA and protein sequences [528]. The most representative tools for homology detection are BLAST (for pairwise alignment) [529] and CLUSTAL (for multiple sequence alignment) [530]. Wang et al. used BLASTP (searches protein databases against a query protein), the nearest neighbor algorithm, and a feature selection approach involving amino acid and pseudoamino acid composition including codon diversity, electrostatic charge, polarity, molecular volume, and the secondary structure to create an AMP prediction tool [531].

\subsection{Pattern-Matching}

Pattern matching strategies are more efficient than the sequence alignment method, reducing computational time while simultaneously detecting more remote protein homologs. The Profile Hidden Markov Model (profile-HMM) is the most widely used pattern matching strategy [526].

\subsection{Profile-HMM}

The profile-HMM is a probabilistic, sensitive approach for detecting distant homology from multiple sequence alignments [526]. This approach generates a profile from a multiple sequence alignment and then subjects it to HMMER (a profile-HMM tool widely used in protein family databases such as Interpro and Pfam $[532,533]$ ) to determine the evolutionary events that took place in a set of related sequences.

A drawback of the profile-HMM approach is peptide promiscuity, namely the ability of an AMP to perform different functions when exposed to different environmental conditions [534]. As a conserved peptide detected by local alignment or pattern detection may not have antimicrobial activity [535], effective computational prediction tools for activity are needed. To this end, machine learning approaches have been applied in detecting potential AMPs.

\subsection{Machine Learning and Deep Learning}

Machine learning involves the construction of computer systems that employ artificial intelligence (AI) algorithms which automatically learn from data and improve through experience [536]. It can be classified into (i) supervised learning in which input data are labelled prior by the user to train the system [537], and (ii) unsupervised learning where no pre-existing labels are provided [538]. Supervised learning methods utilized in AMP prediction include artificial neural networks (ANN), support vector machines $(\mathrm{SVM})$, quantitative matrices, random forests (RF), k-nearest neighbors (k-NN), and selforganized maps (SOM) [539]. Deep learning is a subfield of machine learning that structures algorithms in layers, creating an "artificial neural network". It was recently used to accurately predict protein structures even in the absence of known similar structures [540].

Support vector machine (SVM) is a supervised learning method operating on a set of well-characterized vectors that learns classifiers used to classify data [541]. In this regard, a combined sequence alignment method utilizing Lempel-Ziv (LZ) complexity and SVMpairwise algorithm which enables rapid and effective peptide prediction was proposed by Ng. et al. [542]. Random forest algorithm is based on the combination of decision trees from the feature vectors. The inference is made on votes cast by the trees [543], an example being the identification and prediction of antitubercular peptides using a combined RF and SVM algorithm [544]. For the prediction of lantibiotics, a combination of four different ML algorithms (SVM, Sequential minimal optimization (SMO), naïve bayes (NB), and RF) was implemented [545]. Deep learning algorithms have also been implemented to predict and identify AMPs. A multi-scale convolutional network model (deep neural network) outperformed existing state-of-the-art models when used for AMP discovery [546], and a 
long short-term memory (LSTM) generative model and bidirectional LSTM classification model were effective at generating novel antibacterial AMPs that could be utilized as new antibiotic leads [547]. SVM combined with deep learning-based features identified 436 possible antimicrobial proteins in the genome of Helobdella robusta [548]. Discriminant analysis (DA), which is a multivariate approach [549], quadratic discriminate analysis [550], and conditional random fields [551] may also be used for AMP prediction.

\subsection{Molecular Dynamics (MD) Simulations}

As the number of peptides discovered increases exponentially, studying their antimicrobial activity and mode of action is challenging. Use of MD simulations is a comparatively convenient method to investigate the activity and mode of action of AMPs [552]. Advancements in MD simulations have been driven by improvements in hardware, mathematical modeling, and algorithms, as well as the development of new force fields that better parameterize the chemical interactions. MD simulations at atomic resolution have been successful in determining peptide binding and folding, partitioning into lipid bilayers, and how the peptide channels that conduct ionic and other material across membranes form [553]. A few examples of recent successes using MD simulations include the rational peptide design approach to describe, at the microseconds scale, the interaction of indolicidin with membranes and design indolicidin analogues with enhanced antimicrobial activity and low hemolysis [554], and the determination of the structural stability and compactness of 37 lantibiotics using dynamics simulations [555]. The latter study revealed a lack of correlation between the structural and sequence diversity of lantibiotics, a property that could be explored to design novel, higher efficacy lantipeptides. The use of MD simulations in combination with prediction algorithms has also been used to improve the activity of peptides, resulting in the discovery of potent antibacterial AMPs [556]. Talandashti et al. used all-atom and coarse-grained MD simulations to gain molecular-level insights into pleuricidin pore-formation and its associated antimicrobial activity [557]. A similar process was used by Catte et al. to determine the mechanism of membrane interaction of chrysophsin-3 (chrys-3), a highly cationic peptide of 20 amino acids from the gills of red sea bream [558]. MD simulation studies have also been used to examine the energetics of melittin and its insertion mechanism in a mimic of a bacterial membrane (DOPC/DOPG mixed bilayer). The energy barrier results from MD were found to be consistent with the free energy estimation of melittin molecules [559]. MD simulations in combination with machine learning have been used in AMP prediction based on 3D descriptors as compared to the traditional 2D descriptors [560]. MD simulations have also played a role in demonstrating the conformation of single and multiple monomers of bombinin $\mathrm{H} 2$, the latter forming self-aggregated structures [561]. Similarly, the carpet-like mechanism of megin peptide was determined by MD in combination with spectroscopy and zeta potential [562]. The mechanism of protegrin-1 (PG-1) pore formation was also determined by multistep MD studies that revealed the insertion, translocation, and induction of the pore [563]. The differential interactions of LL37 with a mimick of bacterial (POPG) and mammalian (POPC) membranes were determined using MD studies [564]. Fengycin, a cyclic lipopeptide with antifungal activity, was shown to form stable oligomers in model fungal membranes using MD [565]. The implementation of a combined deep learning and MD simulation approach also resulted in the rapid discovery of AMPs with high potency against diverse Gram-positive and -negative pathogens (including MDR Klebsiella pneumoniae) [566]. While many other MD studies have been used to examine AMPs, a comprehensive compliling of all of these studies is beyond the scope of this work.

Various applications and web servers available for the prediction and design of AMPs are shown in Table 3. 
Table 3. Tabulated representation of AMP databases/servers for prediction.

\begin{tabular}{|c|c|c|c|c|c|}
\hline Server & Algorithm & Year & Description & URL & Ref \\
\hline CyBase & $\begin{array}{l}\text { ellipsoid and random } \\
\text { walk algorithm }\end{array}$ & 2008 & $\begin{array}{l}\text { database of cyclic protein sequences } \\
\text { and structures }\end{array}$ & $\begin{array}{l}\text { http://www.cybase.org.au/index.php } \\
\text { (accessed on } 22 \text { October 2021) }\end{array}$ & [567] \\
\hline AntiBP2 & SVM & 2010 & $\begin{array}{l}\text { Predict antibacterial peptides in } \\
\text { protein sequences }\end{array}$ & $\begin{array}{l}\text { Www.imtech.res.in/raghava/antibp/ } \\
\text { (accessed on } 2 \text { October 2020) } \\
\text { https://bioinfo-mml.sjtu.edu.cn/ }\end{array}$ & [568] \\
\hline THIOBASE & - & 2011 & Database of thiopeptides & $\begin{array}{l}\text { THIOBASE/index.php (accessed on } 22 \\
\text { October 2021) }\end{array}$ & [569] \\
\hline AvPred & SVM & 2012 & Predict antiviral peptides & $\begin{array}{l}\text { http://crdd.osdd.net/servers/avppred/ } \\
\text { index.html (accessed on } 2 \text { October 2020) }\end{array}$ & [570] \\
\hline ThioFinder & HMMs & 2012 & $\begin{array}{l}\text { Identify thiopeptide antibiotic gene } \\
\text { clusters in DNA sequences }\end{array}$ & $\begin{array}{l}\text { https: / / bioinfo-mml.sjtu.edu.cn/ } \\
\text { ThioFinder/index.php (accessed on } 22 \\
\text { October 2021) }\end{array}$ & [569] \\
\hline ClassAMP & RF, SVM & 2012 & $\begin{array}{l}\text { Predict AMP domains in protein } \\
\text { sequences }\end{array}$ & $\begin{array}{l}\text { http://www.bicnirrh.res.in/classamp/ } \\
\text { (accessed on } 2 \text { October 2020) }\end{array}$ & [571] \\
\hline Mutator 2.0 & Mutator Algorithm & 2012 & $\begin{array}{l}\text { Predict the effect of single or double } \\
\text { amino acid substitutions on the } \\
\text { therapeutic index (TI) of helical } \\
\text { AMPs }\end{array}$ & $\begin{array}{l}\text { http://split4.pmfst.hr/mutator/ } \\
\text { (accessed on } 2 \text { October 2020) }\end{array}$ & [572] \\
\hline DADP & - & 2012 & $\begin{array}{l}\text { Database of bioactive peptides from } \\
\text { anuran }\end{array}$ & $\begin{array}{l}\text { http://split4.pmfst.hr/dadp/ (accessed } \\
\text { on } 22 \text { October 2021) }\end{array}$ & [573] \\
\hline YADAMP & DSC & 2012 & AMP database of and predict AMPs & $\begin{array}{l}\text { http://yadamp.unisa.it/about.aspx } \\
\text { (accessed on } 22 \text { October 2021) }\end{array}$ & [574] \\
\hline CPPpred & N-to-1 NN & 2013 & Predict cell penetrating peptides & $\begin{array}{l}\text { http://bioware.ucd.ie/ compass / } \\
\text { biowareweb/Server_pages / cpppred. } \\
\text { php (accessed on } 2 \text { October 2020) }\end{array}$ & [575] \\
\hline $\mathrm{HIPdb}$ & PepStr algorithm & 2013 & $\begin{array}{l}\text { Database of experimentally } \\
\text { validated anti-HIV Peptides }\end{array}$ & $\begin{array}{l}\text { http://crdd.osdd.net/servers/hipdb/ } \\
\text { (accessed on } 2 \text { October 2020) }\end{array}$ & [576] \\
\hline ADAM & HMM, SVM & 2015 & Predict AMPs & $\begin{array}{l}\text { http: / / bioinformatics.cs.ntou.edu.tw / } \\
\text { ADAM/tool.html (accessed on } 2 \\
\text { October 2020) }\end{array}$ & [577] \\
\hline DBAASP & $\begin{array}{l}\text { New algorithm } \\
\text { DBSCAN }\end{array}$ & 2015 & Predict AMPs & $\begin{array}{l}\text { https://dbaasp.org/home (accessed on } \\
2 \text { October 2020) }\end{array}$ & {$[516]$} \\
\hline BaAMPs & - & 2015 & Database of anti-biofilm AMPs & $\begin{array}{l}\text { http://www.baamps.it/ (accessed on } 22 \\
\text { October 2021) }\end{array}$ & [578] \\
\hline $\mathrm{CAMP}_{\mathrm{R} 3}$ & SVM, RF, ANN, DA & 2016 & Predict AMPs & $\begin{array}{l}\text { http:/ / www.camp3.bicnirrh.res.in/ } \\
\text { index.php (accessed on } 2 \text { October 2020) }\end{array}$ & [549] \\
\hline APD3 & $\begin{array}{l}\text { Peptide Parameter } \\
\text { Space }\end{array}$ & 2016 & Predict AMPs & $\begin{array}{l}\text { http://aps.unmc.edu/AP/main.php } \\
\text { (accessed on } 2 \text { October 2020) }\end{array}$ & [234] \\
\hline dPABBs & SVM, WEKA & 2016 & $\begin{array}{l}\text { Predict and design anti-biofilm } \\
\text { peptides }\end{array}$ & $\begin{array}{l}\text { http://ab-openlab.csir.res.in/abp/ } \\
\text { antibiofilm/ (accessed on } 2 \text { October } \\
\text { 2020) }\end{array}$ & [579] \\
\hline MBPDB & - & 2017 & $\begin{array}{l}\text { Database of bioactive peptides } \\
\text { derived from milk protein }\end{array}$ & $\begin{array}{l}\text { http:/ / mbpdb.nws.oregonstate.edu/ } \\
\text { (accessed on } 22 \text { October 2021) }\end{array}$ & {$[580]$} \\
\hline RiPPMiner & SVM, WEKA & 2017 & $\begin{array}{l}\text { Decipher RiPPs from amino acid } \\
\text { sequence of precursor polypeptide. }\end{array}$ & $\begin{array}{l}\text { http:// www.nii.ac.in/rippminer.html } \\
\text { (accessed on } 22 \text { October 2021) }\end{array}$ & [581] \\
\hline iAMPpred & SVM & 2017 & Predict AMPs & $\begin{array}{l}\text { http:/ / cabgrid.res.in:8080/amppred/ } \\
\text { (accessed on } 22 \text { October 2021) }\end{array}$ & [582] \\
\hline InverPep & $\begin{array}{l}\text { CALCAMP/in-house } \\
\text { algorithm }\end{array}$ & 2017 & $\begin{array}{l}\text { Database of experimentally } \\
\text { validated AMPs from invertebrates }\end{array}$ & $\begin{array}{l}\text { https://ciencias.medellin.unal.edu.co/ } \\
\text { gruposdeinvestigacion/ } \\
\text { prospeccionydisenobiomoleculas/ } \\
\text { InverPep/public/home_en (accessed on } \\
22 \text { October 2021) }\end{array}$ & [583] \\
\hline BAGEL4 & HMM, Genomic context & 2018 & Predicts RiPPs and bacteriocins & $\begin{array}{l}\text { http: / / bagel4.molgenrug.nl (accessed } \\
\text { on } 2 \text { October 2020) }\end{array}$ & [584] \\
\hline AMPscanner Vr.1 & RF \& MARS & 2018 & Predict AMPs & $\begin{array}{l}\text { https:// www.dveltri.com/ascan/v1 } \\
\text { /index.html (accessed on } 2 \text { October } \\
\text { 2020) }\end{array}$ & [585] \\
\hline AMPscanner Vr.2 & $\mathrm{DNN}$ & 2018 & Predict AMPs & $\begin{array}{l}\text { https: / / www.dveltri.com/ascan/v2 } \\
\text { /about.html (accessed on } 2 \text { October } \\
\text { 2020) }\end{array}$ & [585] \\
\hline dbAMP & RF/BLASTP & 2019 & Predict AMPs & $\begin{array}{l}\text { http: } \\
\text { //140.138.77.240/ dbamp/index.php } \\
\text { (accessed on } 2 \text { October 2020) }\end{array}$ & \\
\hline ADAPT-ABLE & $\begin{array}{l}\text { SR family generating, } \\
\text { CF algorithm }\end{array}$ & 2019 & Data mining and AMP prediction & $\begin{array}{l}\text { http://gec.u-picardie.fr/adaptable } \\
\text { (accessed on } 2 \text { October 2020) }\end{array}$ & [515] \\
\hline AMAP & SVM, XGBoost & 2019 & $\begin{array}{l}\text { Predict biologically active peptides } \\
\text { and AMPs. }\end{array}$ & $\begin{array}{l}\text { http:/ /amap.pythonanywhere.com/ } \\
\text { (accessed on } 2 \text { October 2020) } \\
\text { https: }\end{array}$ & [586] \\
\hline AntiVPP1.0 & $\mathrm{RF}$ & 2019 & Predict antiviral peptides. & $\begin{array}{l}\text { //github.com/bio-coding/AntiVPP } \\
\text { (accessed on } 2 \text { October 2020) }\end{array}$ & [587] \\
\hline Meta-iAVP & $\begin{array}{l}\text { k-NN, rpart, glm, RF, } \\
\text { XGB, SVM }\end{array}$ & 2019 & Predict antiviral peptides. & $\begin{array}{l}\text { http: / / codes.bio/meta-iavp / (accessed } \\
\text { on } 2 \text { October 2020) }\end{array}$ & [588] \\
\hline mACPpred & SVM & 2019 & Predict anticancer peptides. & $\begin{array}{l}\text { www.thegleelab.org/mACPpred } \\
\text { (accessed on } 2 \text { October 2020) }\end{array}$ & [589] \\
\hline Deep-AmPEP30 & $\mathrm{CNN}$ & 2020 & Predict AMPs $\leq 30$ residues. & $\begin{array}{l}\text { https:// cbbio.cis.um.edu.mo/AxPEP } \\
\text { (accessed on } 2 \text { October 2020) }\end{array}$ & [590] \\
\hline AmpGram & $\mathrm{RF}$ & 2020 & $\begin{array}{l}\text { Predict and design AMPs from } \\
\text { proteomic data. }\end{array}$ & $\begin{array}{l}\text { http:// biongram.biotech.uni.wroc.pl/ } \\
\text { AmpGram/ (accessed on } 2 \text { October } \\
\text { 2020) }\end{array}$ & [591] \\
\hline
\end{tabular}


Table 3. Cont.

\begin{tabular}{|c|c|c|c|c|c|}
\hline Server & Algorithm & Year & Description & URL & Ref \\
\hline IAMPE & $\begin{array}{l}\text { NB, KNN, SVM, RF, } \\
\text { and XGBoost }\end{array}$ & 2020 & $\begin{array}{l}\text { Predict physicochemical and NMR } \\
\text { features of peptides. }\end{array}$ & $\begin{array}{l}\text { http:// cbb1.ut.ac.ir/ (accessed on } 2 \\
\text { October 2020) }\end{array}$ & [592] \\
\hline CancerGram & $\begin{array}{l}\text { n-grams and random } \\
\text { forests }\end{array}$ & 2020 & Predict anticancer peptides. & $\begin{array}{l}\text { http:// biongram.biotech.uni.wroc.pl/ } \\
\text { CancerGram/ (accessed on } 2 \text { October } \\
\text { 2020) }\end{array}$ & [593] \\
\hline ACEP & DNN & 2020 & Predict AMPs & $\begin{array}{l}\text { https: / / github.com/Fuhaoyi / ACEP } \\
\text { (accessed on } 2 \text { October 2020) }\end{array}$ & [594] \\
\hline AniAMPpred & SVM, DNN & 2021 & $\begin{array}{l}\text { Identify the antimicrobial function } \\
\text { of proteins }\end{array}$ & $\begin{array}{l}\text { https: / / aniamppred.anvil.app/ } \\
\text { (accessed on } 22 \text { October 2021) }\end{array}$ & [548] \\
\hline DRAMP 3.0 & - & 2021 & $\begin{array}{l}\text { Data repository of antimicrobial } \\
\text { peptides and predict AMPs }\end{array}$ & $\begin{array}{l}\text { http:/ / dramp.cpu-bioinfor.org/ } \\
\text { (accessed on } 22 \text { October 2021) }\end{array}$ & [595] \\
\hline
\end{tabular}

ANN, artificial neural network; CNN, convolutional neural network; DA, discriminant analysis; DBSCAN, density-based clustering algorithm; DNN, deep neural network; FKNN, fuzzy K-nearest neighbor; glm, generalized linear model; HMM, hidden Markov model; MARS, Multivariate adaptive regression spline; NB, Naïve Bayes; RF, random forest; rpart, recursive partitioning and regression trees; SVM, support vector machine; WEKA, Waikato Environment for Knowledge Analysis; XGBoost, extreme gradient boosting.

\section{Discussion}

The Infectious Diseases Society of America (IDSA) identified a group of particularly problematic pathogens, termed ESKAPE pathogens (E. faecium, S. aureus, K. pneumoniae, A. baumannii, P. aeruginosa, Enterobacter spp.), requiring urgent effective treatments [596]. These pathogens are known to 'escape' the bactericidal effects of many antibiotics via multiple drug resistance mechanisms, rendering them almost totally resistant to existing antibiotics [597]. Consequently, interest in AMPs as an alternate therapy for infections caused by such resistant organisms has increased over the last two decades [598]. Here, we have summarised the sources, classification, and mechanism of actions of AMPs, as well as examining a variety of AMP databases and AMP development tools. A unique advantage of AMPs compared to traditional antibiotics is that they have multiple biological targets [599]. This is exemplified by LL-37, which acts on the bacterial cell membrane but also exhibits direct microbicidal, immune modulation, and antibiofilm activity [600,601]. It is therefore not surprising that AMPs are increasingly being examined as potential alternate therapy for infections caused by MDR pathogens [598]. However, of the thousands of AMPs discovered, the United States Food and Drug Administration (FDA) has only approved the glycopeptides (vancomycin, oritavancin, dalbavancin, and telavancin) and daptomycin for use against Gram-positive bacteria, the polymyxins (polymyxin B and colistin [polymyxin E]) for use against Gram-negative bacteria, and gramicidin for use against both Gram-type bacteria [602]. In many countries in Asia and Europe, teicoplanin (a glycopeptide) is also used clinically for the prophylaxis and treatment of serious infections caused by Grampositive bacteria [603]. The nikkomycins and echinocandins are AMPs which are currently being investigated for the treatment of fungal infections caused by Blastomyces dermatitidis, Aspergillus niger, and C. albicans [506].

While AMPs have potential therapeutic benefits compared to existing antibiotics, they also come with certain limitations that hinder their development for use in the clinic. Natural AMPs typically have poor absorption, distribution, metabolism, and excretion (ADME) properties, as well as a short half-life and low permeability and solubility [604]. These properties have proven to be a major hindrance to the development of novel AMP treatments. Several studies have demonstrated that certain properties of AMPs, including ADME, cytotoxicity, and proteolytic stability, can be modulated by altering the peptide composition and post translational modifications [605-607]. Strategies to help turn peptides into potentially useful medicines have been comprehensively reviewed elsewhere [604]. Prediction tools utilizing machine learning algorithms with an accuracy, sensitivity, and specificity of $\geq 90 \%$ have accelerated peptide discovery as well as resistance-gene prediction in microbial genomes [608]. The in silico approach of MD simulations has provided a better understanding of structure-activity relationships (SARs), including mechanisms of action and the identification of important residues contributing to antibacterial activity [609]. Recent work by Zhu et al. elucidated polymyxin-dependent resistance using MD simulations with other omics approaches [610], while Jiang et al. used MD simula- 
tions to reveal the structure-interaction relationship of polymyxins with the lipid A-based outer membrane of A. baumannii [611]. When combined with experimental validation, MD simulation can elucidate the detailed mechanisms of action at the atomic level, making it especially useful for novel AMP development [552]. Recently, Chen et al. described a new simulation-guided rational design for the development of a small-pore forming AMP [612], whereas Kleandrova et al. described a new method for simultaneously predicting AMP antibacterial activity and cytotoxicity [613].

The conserved structures, specific targeted activities, ease of synthesis, and small size make AMPs promising therapeutic agents. Synthetic and chemical biology has great potential to develop AMPs with enhanced antimicrobial activity and reduced toxicity $[614,615]$. Improvements in MD simulation algorithms and machine learning strategies that will inevitably come with increasing computational power and high spec dedicated systems will greatly assist in the prediction and determination of AMP SARs. Similarly, improved molecular dynamics and deep learning algorithms can be developed to extract extensive features from already reported antimicrobial, non-antimicrobial, cytotoxic, and non-cytotoxic AMPs. The mining of halicin for resistant infections is a promising example of deep learning in the drug discovery and development pipline [616]. Similarly, the advent of alpha fold, which represents a significant breakthrough in computational biology, exemplifies the promise of deep learning approaches in AMPs discovery [540]. A network biology approach can also be adopted for peptide-induced pathways and peptide-protein and peptide-gene interactions, enhancing our understanding of AMP functioning. Finally, the development of robust tools that can simultaneously detect AMP activity, mode of action, cytotoxicity, and other adverse effects would be of great benefit. Nevertheless, wet laboratory assays for determining cytotoxicity as well as activity are still be required.

Overall, we systematically summarize the recent significant progress of AMP on origins, sequences, classifications, structures, and databases. The knowledge and insights would be valuable for drug discovery and treatment development to combat a variety of infectious diseases.

Author Contributions: Conceptualization, Y.Z. and X.J.; methodology, A.B.H., Y.Z. and X.J.; formal analysis, Y.Z., P.J.B.; investigation, A.B.H., X.J. and Y.Z.; curation, A.B.H., Y.Z. and X.J.; writingoriginal draft preparation, A.B.H., Y.Z. and X.J.; writing-review and editing A.B.H., Y.Z., P.J.B.; supervision, Y.Z. All authors have read and agreed to the published version of the manuscript.

Funding: This research received no external funding.

Institutional Review Board Statement: Not applicable.

Informed Consent Statement: Not applicable.

Conflicts of Interest: The authors declare no conflict of interest.

\section{References}

1. Zaman, S.B.; Hussain, M.A.; Nye, R.; Mehta, V.; Mamun, K.T.; Hossain, N. A Review on Antibiotic Resistance: Alarm Bells are Ringing. Cureus 2017, 9, e1403. [CrossRef] [PubMed]

2. WHO Antimicrobial Resistance. Global Report on Surveillance; World Health Organization: Geneva, Switzerland, 2014. [CrossRef]

3. Upton, M.; Cotter, P.; Tagg, J. Antimicrobial peptides as therapeutic agents. Int. J. Microbiol. 2012. [CrossRef] [PubMed]

4. Mahlapuu, M.; Håkansson, J.; Ringstad, L.; Björn, C. Antimicrobial peptides: An emerging category of therapeutic agents. Front. Cell. Infect. Microbiol. 2016, 6. [CrossRef] [PubMed]

5. Dubos, R.J. Studies on a bactericidal agent extracted from a soil bacillus: I. Preparation of the agent. Its activity in vitro. J. Exp. Med. 1939, 70, 1-10. [CrossRef] [PubMed]

6. Dubos, R.J. Studies on a bactericidal agent extracted from a soil bacillus: II. Protective effect of the bactericidal agent against experimental pieuococcus infections in mice. J. Exp. Med. 1939, 70, 11-18. [CrossRef] [PubMed]

7. Pasupuleti, M.; Schmidtchen, A.; Malmsten, M. Antimicrobial peptides: Key components of the innate immune system. Crit. Rev. Biotechnol. 2012, 32, 143-171. [CrossRef] [PubMed]

8. Chen, C.H.; Lu, T.K. Development and challenges of antimicrobial peptides for therapeutic applications. Antibiotics 2020, 9, 24. [CrossRef] [PubMed] 
9. Chromek, M.; Slamová, Z.; Bergman, P.; Kovács, L.; Podracká, L.; Ehrén, I.; Hökfelt, T.; Gudmundsson, G.H.; Gallo, R.L.; Agerberth, B.; et al. The antimicrobial peptide cathelicidin protects the urinary tract against invasive bacterial infection. Nat. Med. 2006, 12, 636-641. [CrossRef] [PubMed]

10. Pretzel, J.; Mohring, F.; Rahlfs, S.; Becker, K. Antiparasitic peptides. Adv. Biochem. Eng. Biotechnol. 2013, 135, 157-192. [CrossRef]

11. De Breij, A.; Riool, M.; Cordfunke, R.A.; Malanovic, N.; De Boer, L.; Koning, R.I.; Ravensbergen, E.; Franken, M.; Van Der Heijde, T.; Boekema, B.K.; et al. The antimicrobial peptide SAAP-148 combats drug-resistant bacteria and biofilms. Sci. Transl. Med. 2018, 10. [CrossRef] [PubMed]

12. Ahmed, A.; Siman-Tov, G.; Hall, G.; Bhalla, N.; Narayanan, A. Human antimicrobial peptides as therapeutics for viral infections. Viruses 2019, 11, 704. [CrossRef] [PubMed]

13. Steinstraesser, L.; Kraneburg, U.; Jacobsen, F.; Al-Benna, S. Host defense peptides and their antimicrobial-immunomodulatory duality. Immunobiology 2011, 216, 322-333. [CrossRef] [PubMed]

14. Hancock, R.E.W.; Nijnik, A.; Philpott, D.J. Modulating immunity as a therapy for bacterial infections. Nat. Rev. Microbiol. 2012, 10, 243-254. [CrossRef] [PubMed]

15. Mahlapuu, M.; Björn, C.; Ekblom, J. Antimicrobial peptides as therapeutic agents: Opportunities and challenges. Crit. Rev. Biotechnol. 2020, 40, 978-992. [CrossRef] [PubMed]

16. Wang, C.K.; Craik, D.J. Designing macrocyclic disulfide-rich peptides for biotechnological applications perspective. Nat. Chem. Biol. 2018, 14, 417-427. [CrossRef] [PubMed]

17. Henriques, S.T.; Lawrence, N.; Chaousis, S.; Ravipati, A.S.; Cheneval, O.; Benfield, A.H.; Elliott, A.G.; Kavanagh, A.M.; Cooper, M.A.; Chan, L.Y.; et al. Redesigned Spider Peptide with Improved Antimicrobial and Anticancer Properties. ACS Chem. Biol. 2017, 12, 2324-2334. [CrossRef]

18. Schmelcher, M.; Donovan, D.M.; Loessner, M.J. Bacteriophage endolysins as novel antimicrobials. Future Microbiol. 2012, 7, 1147-1171. [CrossRef]

19. Rodríguez-Rubio, L.; Martínez, B.; Donovan, D.M.; Rodríguez, A.; García, P. Bacteriophage virion-associated peptidoglycan hydrolases: Potential new enzybiotics. Crit. Rev. Microbiol. 2013, 39, 427-434. [CrossRef] [PubMed]

20. Yan, J.; Mao, J.; Xie, J. Bacteriophage polysaccharide depolymerases and biomedical applications. BioDrugs 2014, 28, 265-274. [CrossRef]

21. Parisien, A.; Allain, B.; Zhang, J.; Mandeville, R.; Lan, C.Q. Novel alternatives to antibiotics: Bacteriophages, bacterial cell wall hydrolases, and antimicrobial peptides. J. Appl. Microbiol. 2008, 104, 1-13. [CrossRef] [PubMed]

22. Fischetti, V.A. Bacteriophage lysins as effective antibacterials. Curr. Opin. Microbiol. 2008, 11, 393-400. [CrossRef] [PubMed]

23. Ha, E.; Son, B.; Ryu, S. Clostridium perfringens virulent bacteriophage CPS2 and its thermostable endolysin lysCPS2. Viruses 2018, 10, 251. [CrossRef] [PubMed]

24. Plotka, M.; Kapusta, M.; Dorawa, S.; Kaczorowska, A.K.; Kaczorowski, T. Ts2631 endolysin from the extremophilic thermus scotoductus bacteriophage vB_Tsc2631 as an antimicrobial agent against gram-negative multidrug-resistant bacteria. Viruses 2019, 11, 657. [CrossRef] [PubMed]

25. Pastagia, M.; Schuch, R.; Fischetti, V.A.; Huang, D.B. Lysins: The arrival of pathogen-directed anti-infectives. J. Med. Microbiol. 2013, 62, 1506-1516. [CrossRef] [PubMed]

26. O'Flaherty, S.; Ross, R.P.; Coffey, A. Bacteriophage and their lysins for elimination of infectious bacteria: Review article. FEMS Microbiol. Rev. 2009, 33, 801-819. [CrossRef]

27. Salas, M.; Wernecki, M.; Fernández, L.; Iglesias, B.; Gutiérrez, D.; Álvarez, A.; García, L.; Prieto, E.; García, P.; Rodríguez, A. Characterization of clinical MRSA isolates from Northern Spain and assessment of their susceptibility to phage-derived antimicrobials. Antibiotics 2020, 9, 447. [CrossRef] [PubMed]

28. Peng, S.Y.; You, R.I.; Lai, M.J.; Lin, N.T.; Chen, L.K.; Chang, K.C. Highly potent antimicrobial modified peptides derived from the Acinetobacter baumannii phage endolysin LysAB2. Sci. Rep. 2017, 7, 1-12. [CrossRef]

29. Wei, L.; Wu, J.; Liu, H.; Yang, H.; Rong, M.; Li, D.; Zhang, P.; Han, J.; Lai, R. A mycobacteriophage-derived trehalose-6,6=dimycolatebinding peptide containing both antimycobacterial and anti-inflammatory abilities. FASEB J. 2013, 27, $3067-3077$. [CrossRef]

30. Yoong, P.; Schuch, R.; Nelson, D.; Fischetti, V.A. Identification of a broadly active phage lytic enzyme with lethal activity against antibiotic-resistant Enterococcus faecalis and Enterococcus faecium. J. Bacteriol. 2004, 186, 4808-4812. [CrossRef]

31. Hermoso, J.A.; García, J.L.; García, P. Taking aim on bacterial pathogens: From phage therapy to enzybiotics. Curr. Opin. Microbiol. 2007, 10, 461-472. [CrossRef]

32. Zimmer, M.; Vukov, N.; Scherer, S.; Loessner, M.J. The murein hydrolase of the bacteriophage $\varphi 3626$ dual lysis system is active against all tested Clostridium perfringens strains. Appl. Environ. Microbiol. 2002, 68, 5311-5317. [CrossRef] [PubMed]

33. Rodríguez-Rubio, L.; Martínez, B.; Rodríguez, A.; Donovan, D.M.; García, P. Enhanced staphylolytic activity of the Staphylococcus aureus bacteriophage vB_SauS-phiiPla88 HydH5 Virion-associated peptidoglycan hydrolase: Fusions, deletions, and synergy with LysH5. Appl. Environ. Microbiol. 2012, 78, 2241-2248. [CrossRef] [PubMed]

34. Rodríguez, L.; Martínez, B.; Zhou, Y.; Rodríguez, A.; Donovan, D.M.; García, P. Lytic activity of the virion-associated peptidoglycan hydrolase HydH5 of Staphylococcus aureus bacteriophage vB-SauS-phiIPLA88. BMC Microbiol. 2011, 11, 1-11. [CrossRef] [PubMed] 
35. Moak, M.; Molineux, I.J. Peptidoglycan hydrolytic activities associated with bacteriophage virions. Mol. Microbiol. 2004, 51, 1169-1183. [CrossRef] [PubMed]

36. Latka, A.; Maciejewska, B.; Majkowska-Skrobek, G.; Briers, Y.; Drulis-Kawa, Z. Bacteriophage-encoded virion-associated enzymes to overcome the carbohydrate barriers during the infection process. Appl. Microbiol. Biotechnol. 2017, 101, 3103-3119. [CrossRef] [PubMed]

37. Molineux, I.J. No syringes please, ejection of phage T7 DNA from the virion is enzyme driven. Mol. Microbiol. 2001, 40, 1-8. [CrossRef] [PubMed]

38. Moak, M.; Molineux, I.J. Role of the Gp16 lytic transglycosylase motif in bacteriophage T7 virions at the initiation of infection. Mol. Microbiol. 2000, 37, 345-355. [CrossRef] [PubMed]

39. Caldentey, J.; Bamford, D.H. The lytic enzyme of the Pseudomonas phage $\varphi 6$. Purification and biochemical characterization. Biochim. Biophys. Acta (BBA)/Protein Struct. Mol. 1992, 1159, 44-50. [CrossRef]

40. Weng, S.F.; Fu, Y.C.; Lin, J.W.; Tseng, T.T. Identification of a Broad-Spectrum Peptidoglycan Hydrolase Associated with the Particle of Xanthomonas oryzae Phage Xop411. J. Mol. Microbiol. Biotechnol. 2018, 28, 78-86. [CrossRef] [PubMed]

41. Leiman, P.G.; Molineux, I.J. Evolution of a new enzyme activity from the same motif fold. Mol. Microbiol. 2008, 69, 287-290. [CrossRef]

42. Pan, Y.J.; Lin, T.L.; Lin, Y.T.; Su, P.A.; Chen, C.T.; Hsieh, P.F.; Hsu, C.R.; Chen, C.C.; Hsieh, Y.C.; Wang, J.T. Identification of capsular types in carbapenem-resistant klebsiella pneumoniae strains by wzc sequencing and implications for capsule depolymerase treatment. Antimicrob. Agents Chemother. 2015, 59, 1038-1047. [CrossRef] [PubMed]

43. Pan, Y.-J.; Lin, T.-L.; Chen, C.-C.; Tsai, Y.-T.; Cheng, Y.-H.; Chen, Y.-Y.; Hsieh, P.-F.; Lin, Y.-T.; Wang, J.-T. Klebsiella Phage $\Phi$ K64-1 Encodes Multiple Depolymerases for Multiple Host Capsular Types. J. Virol. 2017, 91. [CrossRef]

44. Cornelissen, A.; Ceyssens, P.J.; Krylov, V.N.; Noben, J.P.; Volckaert, G.; Lavigne, R. Identification of EPS-degrading activity within the tail spikes of the novel Pseudomonas putida phage AF. Virology 2012, 434, 251-256. [CrossRef] [PubMed]

45. Carson, L.; Gorman, S.P.; Gilmore, B.F. The use of lytic bacteriophages in the prevention and eradication of biofilms of Proteus mirabilis and Escherichia coli. FEMS Immunol. Med. Microbiol. 2010, 59, 447-455. [CrossRef] [PubMed]

46. Meng, X.; Shi, Y.; Ji, W.; Meng, X.; Zhang, J.; Wang, H.; Lu, C.; Sun, J.; Yan, Y. Application of a bacteriophage lysin to disrupt biofilms formed by the animal pathogen Streptococcus suis. Appl. Environ. Microbiol. 2011, 77, 8272-8279. [CrossRef] [PubMed]

47. Chibeu, A.; Lingohr, E.J.; Masson, L.; Manges, A.; Harel, J.; Ackermann, H.W.; Kropinski, A.M.; Boerlin, P. Bacteriophages with the ability to degrade uropathogenic Escherichia Coli biofilms. Viruses 2012, 4, 471-487. [CrossRef] [PubMed]

48. Young, R.; Bläsi, U. Holins: Form and function in bacteriophage lysis. FEMS Microbiol. Rev. 1995, 17, 191-205. [CrossRef]

49. Young, R. Bacteriophage holins: Deadly diversity. J. Mol. Microbiol. Biotechnol. 2002, 4, 21-36. [PubMed]

50. Wang, I.N.; Smith, D.L.; Young, R. Holins: The protein clocks of bacteriophage infections. Annu. Rev. Microbiol. 2000, 54, 799-825. [CrossRef] [PubMed]

51. Wang, I.N.; Deaton, J.; Young, R. Sizing the holin lesion with an endolysin- $\beta$-galactosidase fusion. J. Bacteriol. 2003, 185, 779-787. [CrossRef]

52. Krupovič, M.; Bamford, D.H. Holin of bacteriophage lambda: Structural insights into a membrane lesion. Mol. Microbiol. 2008, 69, 781-783. [CrossRef] [PubMed]

53. Pang, T.; Fleming, T.C.; Pogliano, K.; Young, R. Visualization of pinholin lesions in vivo. Proc. Natl. Acad. Sci. USA 2013, 110. [CrossRef] [PubMed]

54. Song, J.; Niu, W.; Wu, R.; Wang, J.; Lei, L.; Han, W.; Gu, J. The Phage Holin HolGH15 Exhibits Potential As an Antibacterial Agent to Control Listeria monocytogenes. Foodborne Pathog. Dis. 2020. [CrossRef]

55. Song, J.; Xia, F.; Jiang, H.; Li, X.; Hu, L.; Gong, P.; Lei, L.; Feng, X.; Sun, C.; Gu, J.; et al. Identification and characterization of HolGH15: The Holin of Staphylococcus Aureus bacteriophage GH15. J. Gen. Virol. 2016, 97, 1272-1281. [CrossRef] [PubMed]

56. Lu, N.; Sun, Y.; Wang, Q.; Qiu, Y.; Chen, Z.; Wen, Y.; Wang, S.; Song, Y. Cloning and characterization of endolysin and holin from Streptomyces avermitilis bacteriophage phiSASD1 as potential novel antibiotic candidates. Int. J. Biol. Macromol. 2020, 147, 980-989. [CrossRef] [PubMed]

57. Tajbakhsh, M.; Karimi, A.; Fallah, F.; Akhavan, M.M. Overview of ribosomal and non-ribosomal antimicrobial peptides produced by Gram positive bacteria. Cell. Mol. Biol. 2017, 6, 20. [CrossRef] [PubMed]

58. Diep, D.; Nes, I. Ribosomally Synthesized Antibacterial Peptides in Gram Positive Bacteria. Curr. Drug Targets 2005, 3, 107-122. [CrossRef] [PubMed]

59. Yeaman, M.R.; Yount, N.Y. Mechanisms of antimicrobial peptide action and resistance. Pharmacol. Rev. 2003, 55, 27-55. [CrossRef] [PubMed]

60. Hill, C.; Draper, L.; Ross, R.; Cotter, P. Lantibiotic Immunity. Curr. Protein Pept. Sci. 2008, 9, 39-49. [CrossRef]

61. Simons, A.; Alhanout, K.; Duval, R.E. Bacteriocins, antimicrobial peptides from bacterial origin: Overview of their biology and their impact against multidrug-resistant bacteria. Microorganisms 2020, 8, 639. [CrossRef] [PubMed]

62. Bierbaum, G.; Szekat, C.; Josten, M.; Heidrich, C.; Kempter, C.; Jung, G.; Sahl, H.G. Engineering of a novel thioether bridge and role of modified residues in the lantibiotic Pep5. Appl. Environ. Microbiol. 1996, 62, 385-392. [CrossRef]

63. Sahl, H.-G.; Jack, R.W.; Bierbaum, G. Biosynthesis and Biological Activities of Lantibiotics with Unique Post-Translational Modifications. Eur. J. Biochem. 1995, 230, 827-853. [CrossRef] 
64. Nishie, M.; Nagao, J.I.; Sonomoto, K. Antibacterial peptides "bacteriocins": An overview of their diverse characteristics and applications. Biocontrol Sci. 2012, 17, 1-16. [CrossRef] [PubMed]

65. Willey, J.M.; Van Der Donk, W.A. Lantibiotics: Peptides of diverse structure and function. Annu. Rev. Microbiol. 2007, 61, 477-501. [CrossRef] [PubMed]

66. Xie, L.; Van Der Donk, W.A. Post-translational modifications during lantibiotic biosynthesis. Curr. Opin. Chem. Biol. 2004, 8 , 498-507. [CrossRef] [PubMed]

67. Guder, A.; Wiedemann, I.; Sahl, H. Posttranslationally modified bacteriocins-the lantibiotics. Biopolymers 2000, 55, 62-73. [CrossRef]

68. Bierbaum, G.; Sahl, H.-G. Lantibiotics: Mode of Action, Biosynthesis and Bioengineering. Curr. Pharm. Biotechnol. 2009, 10, 2-18. [CrossRef] [PubMed]

69. Hasper, H.E.; Kramer, N.E.; Smith, J.L.; Hillman, J.D.; Zachariah, C.; Kuipers, O.P.; De Kruijff, B.; Breukink, E. An alternative bactericidal mechanism of action for lantibiotic peptides that target lipid II. Science 2006, 313, 1636-1637. [CrossRef] [PubMed]

70. Hsu, S.T.D.; Breukink, E.; Tischenko, E.; Lutters, M.A.G.; De Kruijff, B.; Kaptein, R.; Bonvin, A.M.J.J.; Van Nuland, N.A.J. The nisin-lipid II complex reveals a pyrophosphate cage that provides a blueprint for novel antibiotics. Nat. Struct. Mol. Biol. 2004, 11, 963-967. [CrossRef]

71. Müller, A.; Ulm, H.; Reder-Christ, K.; Sahl, H.G.; Schneider, T. Interaction of type A lantibiotics with undecaprenol-bound cell envelope precursors. Microb. Drug Resist. 2012, 18, 261-270. [CrossRef]

72. Wiedemann, I.; Breukink, E.; Van Kraaij, C.; Kuipers, O.P.; Bierbaum, G.; De Kruifff, B.; Sahl, H.G. Specific binding of nisin to the peptidoglycan precursor lipid II combines pore formation and inhibition of cell wall biosynthesis for potent antibiotic activity. $J$. Biol. Chem. 2001, 276, 1772-1779. [CrossRef] [PubMed]

73. Barbour, A.; Philip, K.; Muniandy, S. Enhanced Production, Purification, Characterization and Mechanism of Action of Salivaricin 9 Lantibiotic Produced by Streptococcus salivarius NU10. PLoS ONE 2013, 8. [CrossRef] [PubMed]

74. Geng, M.; Austin, F.; Shin, R.; Smith, L. Covalent structure and bioactivity of the type All lantibiotic salivaricin A2. Appl. Environ. Microbiol. 2018, 84. [CrossRef] [PubMed]

75. Barbour, A.; Tagg, J.; Abou-Zied, O.K.; Philip, K. New insights into the mode of action of the lantibiotic salivaricin B. Sci. Rep. 2016, 6. [CrossRef] [PubMed]

76. Zitzer, A.; Palmer, M.; Weller, U.; Wassenaar, T.; Biermann, C.; Tranum-Jensen, J.; Bhakdi, S. Mode of primary binding to target membranes and pore formation induced by Vibrio cholerae cytolysin (hemolysin). Eur. J. Biochem. 1997, 247, 209-216. [CrossRef] [PubMed]

77. Kumar Rai, A.; Chattopadhyay, K. Vibrio cholerae cytolysin: Structure-function mechanism of an atypical $\beta$-barrel pore- forming toxin. Adv. Exp. Med. Biol. 2015, 842, 109-125. [CrossRef]

78. Jack, R.W.; Tagg, J.R.; Ray, B. Bacteriocins of gram-positive bacteria. Microbiol. Rev. 1995, 59, 171-200. [CrossRef] [PubMed]

79. Nissen-Meyer, J.; Oppegård, C.; Rogne, P.; Haugen, H.S.; Kristiansen, P.E. Structure and mode-of-action of the two-peptide (class-Ilb) bacteriocins. Probiotics Antimicrob. Proteins 2010, 2, 52-60. [CrossRef] [PubMed]

80. Oscáriz, J.C.; Pisabarro, A.G. Classification and mode of action of membrane-active bacteriocins produced by gram-positive bacteria. Int. Microbiol. 2001, 4, 13-19. [CrossRef] [PubMed]

81. Fimland, G.; Johnsen, L.; Dalhus, B.; Nissen-Meyer, J. Pediocin-like antimicrobial peptides (class IIa bacteriocins) and their immunity proteins: Biosynthesis, structure, and mode of action. J. Pept. Sci. 2005, 11, 688-696. [CrossRef] [PubMed]

82. Cotter, P.D.; Hill, C.; Ross, R.P. Food microbiology: Bacteriocins: Developing innate immunity for food. Nat. Rev. Microbiol. 2005, 3, 777-788. [CrossRef] [PubMed]

83. Green, G.; Dicks, L.M.T.; Bruggeman, G.; Vandamme, E.J.; Chikindas, M.L. Pediocin PD-1, a bactericidal antimicrobial peptide from Pediococcus damnosus NCFB 1832. J. Appl. Microbiol. 1997, 83, 127-132. [CrossRef] [PubMed]

84. Devi, S.M.; Halami, P.M. Detection and characterization of pediocin PA-1/AcH like bacteriocin producing lactic acid bacteria. Curr. Microbiol. 2011, 63, 181-185. [CrossRef] [PubMed]

85. Cintas, L.M.; Casaus, P.; Håvarstein, L.S.; Hernández, P.E.; Nes, I.F. Biochemical and genetic characterization of enterocin P, a novel sec- dependent bacteriocin from Enterococcus faecium P13 with a broad antimicrobial spectrum. Appl. Environ. Microbiol. 1997, 63, 4321-4330. [CrossRef] [PubMed]

86. Nissen-Meyer, J.; Rogne, P.; Oppegard, C.; Haugen, H.; Kristiansen, P. Structure-Function Relationships of the Non-LanthionineContaining Peptide (class II) Bacteriocins Produced by Gram-Positive Bacteria. Curr. Pharm. Biotechnol. 2009, 10, 19-37. [CrossRef] [PubMed]

87. Chikindas, M.L.; Garcia-Garcera, M.J.; Driessen, A.J.M.; Ledeboer, A.M.; Nissen- Meyer, J.; Nes, I.F.; Abee, T.; Konings, W.N.; Venema, G. Pediocin PA-1, a bacteriocin from Pediococcus acidilactici PAC1.0, forms hydrophilic pores in the cytoplasmic membrane of target cells. Appl. Environ. Microbiol. 1993, 59, 3577-3584. [CrossRef] [PubMed]

88. Héchard, Y.; Sahl, H.G. Mode of action of modified and unmodified bacteriocins from Gram-positive bacteria. Biochimie 2002, 84, 545-557. [CrossRef]

89. Abee, T.; Klaenhammer, T.R.; Letellier, L. Kinetic studies of the action of lactacin F, a bacteriocin produced by Lactobacillus johnsonii that forms poration complexes in the cytoplasmic membrane. Appl. Environ. Microbiol. 1994, 60, 1006-1013. [CrossRef] [PubMed] 
90. Moll, G.; Ubbink-Kok, T.; Hildeng-Hauge, H.; Nissen-Meyer, J.; Nes, I.F.; Konings, W.N.; Driessen, A.J.M. Lactococcin G is a potassium ion-conducting, two-component bacteriocin. J. Bacteriol. 1996, 178, 600-605. [CrossRef] [PubMed]

91. Moll, G.; Hildeng-hauge, H.; Nissen-meyer, J.; Nes, I.F.; Konings, W.N.; Driessen, A.J.M. Mechanistic properties of the twocomponent bacteriocin lactococcin G. J. Bacteriol. 1998, 180, 96-99. [CrossRef]

92. Rea, M.C.; Ross, R.P.; Cotter, P.D.; Hill, C. Classification of Bacteriocins from Gram-Positive Bacteria. In Prokaryotic Antimicrobial Peptides; Springer: New York, NY, USA, 2011; pp. 29-53.

93. Zendo, T. Screening and characterization of novel bacteriocins from lactic acid bacteria. Biosci. Biotechnol. Biochem. 2013, 77, 893-899. [CrossRef] [PubMed]

94. Van Belkum, M.J.; Martin-Visscher, L.A.; Vederas, J.C. Structure and genetics of circular bacteriocins. Trends Microbiol. 2011, 19, 411-418. [CrossRef] [PubMed]

95. Vaughan, E.E.; Daly, C.; Fitzgerald, G.F. Identification and characterization of helveticin V-1829, a bacteriocin produced by Lactobacillus helveticus 1829. J. Appl. Bacteriol. 1992, 73, 299-308. [CrossRef] [PubMed]

96. Kumariya, R.; Garsa, A.K.; Rajput, Y.S.; Sood, S.K.; Akhtar, N.; Patel, S. Bacteriocins: Classification, synthesis, mechanism of action and resistance development in food spoilage causing bacteria. Microb. Pathog. 2019, 128, 171-177. [CrossRef] [PubMed]

97. Heng, N.C.K.; Tagg, J.R. What's in a name? Class distinction for bacteriocins. Nat. Rev. Microbiol. 2006, 4, 160. [CrossRef]

98. Heng, N.C.K.; Wescombe, P.A.; Burton, J.P.; Jack, R.W.; Tagg, J.R. The Diversity of Bacteriocins in Gram-Positive Bacteria. Bacteriocins 2007, 45-92. [CrossRef]

99. da Silva Sabo, S.; Vitolo, M.; González, J.M.D.; de Souza Oliveira, R.P. Overview of Lactobacillus plantarum as a promising bacteriocin producer among lactic acid bacteria. Food Res. Int. 2014, 64, 527-536. [CrossRef] [PubMed]

100. De Martinis, E.C.P.; Alves, V.F.; Franco, B.D.G.M. Fundamentals and perspectives for the use of bacteriocins produced by lactic acid bacteria in meat products. Food Rev. Int. 2002, 18, 191-208. [CrossRef]

101. Benedict, R.G.; Langlykke, A.F. Antibiotic activity of Bacillus polymyxa. J. Bacteriol. 1947, 54, 24. [PubMed]

102. Stansly, P.G.; Shepherd, R.G.; White, H.J. Polymyxin: A new chemotherapeutic agent. Bull. Johns Hopkins Hosp. 1947, 81, 43-54. [PubMed]

103. Velkov, T.; Thompson, P.E.; Azad, M.A.K.; Roberts, K.D.; Bergen, P.J. History, Chemistry and Antibacterial Spectrum. Adv. Exp. Med. Biol. 2019, 1145, 15-36. [CrossRef] [PubMed]

104. Shrivastava, S.R.; Shrivastava, P.S.; Ramasamy, J. World health organization releases global priority list of antibiotic-resistant bacteria to guide research, discovery, and development of new antibiotics. JMS J. Med. Soc. 2018, 32, 76-77. [CrossRef]

105. Deris, Z.Z.; Akter, J.; Sivanesan, S.; Roberts, K.D.; Thompson, P.E.; Nation, R.L.; Li, J.; Velkov, T. A secondary mode of action of polymyxins against Gram-negative bacteria involves the inhibition of NADH-quinone oxidoreductase activity. J. Antibiot. 2014, 67, 147-151. [CrossRef] [PubMed]

106. Sampson, T.R.; Liu, X.; Schroeder, M.R.; Kraft, C.S.; Burd, E.M.; Weiss, D.S. Rapid killing of Acinetobacter baumannii by polymyxins is mediated by a hydroxyl radical death pathway. Antimicrob. Agents Chemother. 2012, 56, 5642-5649. [CrossRef] [PubMed]

107. Riley, M.; Chavan, M. (Eds.) Bacteriocins: Ecology and Evolution; Springer: Berlin/Heidelberg, Germany, $2007 ;$ p. 150.

108. Cascales, E.; Buchanan, S.K.; Duché, D.; Kleanthous, C.; Lloubès, R.; Postle, K.; Riley, M.; Slatin, S.; Cavard, D. Colicin Biology. Microbiol. Mol. Biol. Rev. 2007, 71, 158-229. [CrossRef] [PubMed]

109. Gillor, O.; Kirkup, B.C.; Riley, M.A. Colicins and microcins: The next generation antimicrobials. Adv. Appl. Microbiol. 2004, 54, 129-146. [CrossRef] [PubMed]

110. Papadakos, G.; Wojdyla, J.A.; Kleanthous, C. Nuclease colicins and their immunity proteins. Q. Rev. Biophys. 2012, 45, 57-103. [CrossRef] [PubMed]

111. Parret, A.H.A.; De Mot, R. Bacteria killing their own kind: Novel bacteriocins of Pseudomonas and other $\gamma$-proteobacteria. Trends Microbiol. 2002, 10, 107-112. [CrossRef]

112. Denkovskienė, E.; Paškevičius, Š.; Misiūnas, A.; Stočkūnaitè, B.; Starkevič, U.; Vitkauskienè, A.; Hahn-Löbmann, S.; Schulz, S.; Giritch, A.; Gleba, Y.; et al. Broad and Efficient Control of Klebsiella Pathogens by Peptidoglycan-Degrading and Pore-Forming Bacteriocins Klebicins. Sci. Rep. 2019, 9. [CrossRef] [PubMed]

113. Michel-Briand, Y.; Baysse, C. The pyocins of Pseudomonas aeruginosa. Biochimie 2002, 84, 499-510. [CrossRef]

114. Asensio, C.; Pérez-Díaz, J.C.; Martínez, M.C.; Baquero, F. A new family of low molecular weight antibiotics from enterobacteria. Biochem. Biophys. Res. Commun. 1976, 69, 7-14. [CrossRef]

115. Jack, R.W.; Jung, G. Lantibiotics and microcins: Polypeptides with unusual chemical diversity. Curr. Opin. Chem. Biol. 2000, 4, 310-317. [CrossRef]

116. Duquesne, S.; Destoumieux-Garzón, D.; Peduzzi, J.; Rebuffat, S. Microcins, gene-encoded antibacterial peptides from enterobacteria. Nat. Prod. Rep. 2007, 24, 708-734. [CrossRef] [PubMed]

117. Pons, A.M.; Lanneluc, I.; Cottenceau, G.; Sable, S. New developments in non-post translationally modified microcins. Biochimie 2002, 84, 531-537. [CrossRef]

118. Braun, V.; Patzer, S.I.; Hantke, K. Ton-dependent colicins and microcins: Modular design and evolution. Biochimie 2002, 84, 365-380. [CrossRef]

119. Herrero, M.; Moreno, F. Microcin B17 blocks DNA replication and induces the SOS system in Escherichia coli. J. Gen. Microbiol. 1986, 132, 393-402. [CrossRef] [PubMed] 
120. Adelman, K.; Yuzenkova, J.; La Porta, A.; Zenkin, N.; Lee, J.; Lis, J.T.; Borukhov, S.; Wang, M.D.; Severinov, K. Molecular mechanism of transcription inhibition by peptide antibiotic Microcin J25. Mol. Cell 2004, 14, 753-762. [CrossRef] [PubMed]

121. Rintoul, M.R.; De Arcuri, B.F.; Morero, R.D. Effects of the antibiotic peptide microcin J25 on liposomes: Role of acyl chain length and negatively charged phospholipid. Biochim. Biophys. Acta Biomembr. 2000, 1509, 65-72. [CrossRef]

122. Scholl, D. Phage Tail-Like Bacteriocins. Annu. Rev. Virol. 2017, 4, 453-467. [CrossRef] [PubMed]

123. Daw, M.A.; Falkiner, F.R. Bacteriocins: Nature, function and structure. Micron 1996, 27, 467-479. [CrossRef]

124. Morse, S.A.; Jones, B.V.; Lysko, P.G. Pyocin inhibition of Neisseria gonorrhoea: Mechanism of action. Antimicrob. Agents Chemother. 1980, 18, 416-423. [CrossRef] [PubMed]

125. Lee, G.; Chakraborty, U.; Gebhart, D.; Govoni, G.R.; Zhou, Z.H.; Scholl, D. F-type bacteriocins of Listeria monocytogenes: A new class of phage tail-like structures reveals broad parallel coevolution between tailed bacteriophages and high-molecular-weight bacteriocins. J. Bacteriol. 2016, 198, 2784-2793. [CrossRef]

126. Duclohier, H. Antimicrobial Peptides and Peptaibols, Substitutes for Conventional Antibiotics. Curr. Pharm. Des. 2010, 16, 3212-3223. [CrossRef]

127. Wu, J.; Gao, B.; Zhu, S. The fungal defensin family enlarged. Pharmaceuticals 2014, 7, 866-880. [CrossRef]

128. Bissett, J.; Gams, W.; Jaklitsch, W.; Samuels, G.J. Accepted Trichoderma names in the year 2015. IMA Fungus 2015, 6, 263-295. [CrossRef] [PubMed]

129. Leitgeb, B.; Szekeres, A.; Manczinger, L.; Vágvölgyi, C.; Kredics, L. The history of Alamethicin: A review of the most extensively studied peptaibol. Chem. Biodivers. 2007, 4, 1027-1051. [CrossRef] [PubMed]

130. Benedetti, E.; Bavoso, A.; Di Blasio, B.; Pavone, V.; Pedone, C.; Toniolo, C.; Bonora, G.M. Peptaibol antibiotics: A study on the helical structure of the 2-9 sequence of emerimicins III and IV. Proc. Natl. Acad. Sci. USA 1982, 79, 7951-7954. [CrossRef] [PubMed]

131. Whitmore, L.; Wallace, B.A. The Peptaibol Database: A database for sequences and structures of naturally occurring peptaibols. Nucleic Acids Res. 2004, 32. [CrossRef]

132. Meyer, C.E.; Reusser, F. A polypeptide antibacterial agent isolated from Trichoderma viride. Experientia 1967, 23, 85-86. [CrossRef] [PubMed]

133. De Zotti, M.; Biondi, B.; Formaggio, F.; Toniolo, C.; Stella, L.; Park, Y.; Hahm, K.S. Trichogin GA IV: An antibacterial and protease-resistant peptide. J. Pept. Sci. 2009, 15, 615-619. [CrossRef] [PubMed]

134. Rebuffat, S.; Prigent, Y.; Auvin-Guette, C.; Bodo, B. Tricholongins BI and BII, 19-residue peptaibols from Trichoderma longibrachiatum Solution structure from two-dimensional NMR spectroscopy. Eur. J. Biochem. 1991, 201, 661-674. [CrossRef]

135. Rebuffat, S.; Conraux, L.; Massias, M.; Auvin-Guette, C.; Bodo, B. Sequence and solution conformation of the 20-residue peptaibols, saturnisporins SA II and SA IV. Int. J. Pept. Protein Res. 1993, 41, 74-84. [CrossRef] [PubMed]

136. Qi, J.; Wu, J.; Somkuti, G.A.; Watson, J.T. Determination of the disulfide structure of sillucin, a highly knotted, cysteine-rich peptide, by cyanylation/cleavage mass mapping. Biochemistry 2001, 40, 4531-4538. [CrossRef]

137. Bradley, W.A.; Somkuti, G.A. The primary structure of sillucin and antimicrobial peptide from mucor pusillus. FEBS Lett. 1979, 97, 81-83. [CrossRef]

138. Ramachander Turaga, V.N. Peptaibols: Antimicrobial peptides from fungi. In Bioactive Natural Products in Drug Discovery; Springer: Singapore, 2020; pp. 713-730. ISBN 9789811513947.

139. Wallace, B.A.; Chugh, J. Peptaibols: Models for Ion Channels. Biochem. Soc. Trans. 2001, 29, A54. [CrossRef]

140. Chugh, J.K.; Brückner, H.; Wallace, B.A. Model for a helical bundle channel based on the high-resolution crystal structure of trichotoxin_A50E. Biochemistry 2002, 41, 12934-12941. [CrossRef] [PubMed]

141. He, H.; Janso, J.E.; Yang, H.Y.; Bernan, V.S.; Lin, S.L.; Yu, K. Culicinin D, an antitumor peptaibol produced by the fungus Culicinomyces clavisporus, strain LL-12I252. J. Nat. Prod. 2006, 69, 736-741. [CrossRef] [PubMed]

142. Csermely, P.; Radics, L.; Rossi, C.; Szamel, M.; Ricci, M.; Mihály, K.; Somogyi, J. The nonapeptide leucinostatin A acts as a weak ionophore and as an immunosuppressant on T lymphocytes. BBA Mol. Cell Res. 1994, 1221, 125-132. [CrossRef]

143. Grishin, D.V.; Sokolov, N.N. Defensins are natural peptide antibiotics of higher eukaryotes. Biochem. Suppl. Ser. B Biomed. Chem. 2014, 8, 11-18. [CrossRef]

144. Zhu, S. Discovery of six families of fungal defensin-like peptides provides insights into origin and evolution of the CS $\alpha \beta$ defensins. Mol. Immunol. 2008, 45, 828-838. [CrossRef]

145. Schneider, T.; Kruse, T.; Wimmer, R.; Wiedemann, I.; Sass, V.; Pag, U.; Jansen, A.; Nielsen, A.K.; Mygind, P.H.; Raventós, D.S.; et al. Plectasin, a fungal defensin, targets the bacterial cell wall precursor lipid II. Science 2010, 328, 1168-1172. [CrossRef] [PubMed]

146. Mygind, P.H.; Fischer, R.L.; Schnorr, K.M.; Hansen, M.T.; Sönksen, C.P.; Ludvigsen, S.; Raventós, D.; Buskov, S.; Christensen, B.; De Maria, L.; et al. Plectasin is a peptide antibiotic with therapeutic potential from a saprophytic fungus. Nature 2005, 437 , 975-980. [CrossRef] [PubMed]

147. Essig, A.; Hofmann, D.; Münch, D.; Gayathri, S.; Künzler, M.; Kallio, P.T.; Sahl, H.G.; Wider, G.; Schneider, T.; Aebi, M. Copsin, a novel peptide-based fungal antibiotic interfering with the peptidoglycan synthesis. J. Biol. Chem. 2014, 289, 34953-34964. [CrossRef] [PubMed]

148. Zhu, S.; Gao, B.; Harvey, P.J.; Craik, D.J. Dermatophytic defensin with antiinfective potential. Proc. Natl. Acad. Sci. USA 2012, 109, 8495-8500. [CrossRef] [PubMed]

149. Tam, J.P.; Wang, S.; Wong, K.H.; Tan, W.L. Antimicrobial peptides from plants. Pharmaceuticals 2015, 8, 711-757. [CrossRef] [PubMed] 
150. Hammami, R.; Ben Hamida, J.; Vergoten, G.; Fliss, I. PhytAMP: A database dedicated to antimicrobial plant peptides. Nucleic Acids Res. 2009, 37. [CrossRef] [PubMed]

151. Stec, B. Plant thionins-The structural perspective. Cell. Mol. Life Sci. 2006, 63, 1370-1385. [CrossRef]

152. Pelegrini, P.B.; Franco, O.L. Plant $\gamma$-thionins: Novel insights on the mechanism of action of a multi-functional class of defense proteins. Int. J. Biochem. Cell Biol. 2005, 37, 2239-2253. [CrossRef]

153. Fujimura, M.; Minami, Y.; Watanabe, K.; Tadera, K. Purification, characterization, and sequencing of a novel type of antimicrobial peptides, fa-amp1 and fa-amp2, from seeds of buckwheat (fagopyrum esculentum moench.). Biosci. Biotechnol. Biochem. 2003, 67, 1636-1642. [CrossRef] [PubMed]

154. Beintema, J.J. Structural features of plant chitinases and chitin-binding proteins. FEBS Lett. 1994, 350, 159-163. [CrossRef]

155. Asensio, J.L.; Siebert, H.C.; von der Lieth, C.W.; Laynez, J.; Bruix, M.; Soedjanaamadja, U.M.; Beintema, J.J.; Cañada, F.J.; Gabius, H.J.; Jiménez-Barbero, J. NMR investigations of protein-carbohydrate interactions: Studies on the relevance of Trp/Tyr variations in lectin binding sites as deduced from titration microcalorimetry and NMR studies on hevein domains. Determination of the NMR structure of the complex. Proteins Struct. Funct. Genet. 2000, 40, 218-236. [CrossRef]

156. Pallaghy, P.K.; Norton, R.S.; Nielsen, K.J.; Craik, D.J. A common structural motif incorporating a cystine knot and a triple-stranded $\beta$-sheet in toxic and inhibitory polypeptides. Protein Sci. 1994, 3, 1833-1839. [CrossRef]

157. Duvick, J.P.; Rood, T.; Rao, A.G.; Marshak, D.R. Purification and characterization of a novel antimicrobial peptide from maize (Zea mays L.) kernels. J. Biol. Chem. 1992, 267, 18814-18820. [CrossRef]

158. Marcus, J.P.; Green, J.L.; Goulter, K.C.; Manners, J.M. A family of antimicrobial peptides is produced by processing of a 7S globulin protein in Macadamia integrifolia kernels. Plant J. 1999, 19, 699-710. [CrossRef] [PubMed]

159. Ng, Y.M.; Yang, Y.; Sze, K.H.; Zhang, X.; Zheng, Y.T.; Shaw, P.C. Structural characterization and anti-HIV-1 activities of arginine/glutamate-rich polypeptide Luffin P1 from the seeds of sponge gourd (Luffa cylindrica). J. Struct. Biol. 2011, 174, 164-172. [CrossRef] [PubMed]

160. de Oliveira Carvalho, A.; Gomes, V.M. Role of plant lipid transfer proteins in plant cell physiology-A concise review. Peptides 2007, 28, 1144-1153. [CrossRef] [PubMed]

161. Sels, J.; Mathys, J.; De Coninck, B.M.A.; Cammue, B.P.A.; De Bolle, M.F.C. Plant pathogenesis-related (PR) proteins: A focus on PR peptides. Plant Physiol. Biochem. 2008, 46, 941-950. [CrossRef]

162. Oliveira-Lima, M.; Benko-Iseppon, A.; Neto, J.; Rodriguez-Decuadro, S.; Kido, E.; Crovella, S.; Pandolfi, V. Snakin: Structure, Roles and Applications of a Plant Antimicrobial Peptide. Curr. Protein Pept. Sci. 2016, 18, 368-374. [CrossRef] [PubMed]

163. Su, T.; Han, M.; Cao, D.; Xu, M. Molecular and biological properties of snakins: The foremost cysteine-rich plant host Defense peptides. J. Fungi 2020, 6, 220. [CrossRef] [PubMed]

164. Tavares, L.S.; Rettore, J.V.; Freitas, R.M.; Porto, W.F.; Duque, A.P.D.N.; Singulani, J.D.L.; Silva, O.N.; Detoni, M.D.L.; Vasconcelos, E.G.; Dias, S.C.; et al. Antimicrobial activity of recombinant Pg-AMP1, a glycine-rich peptide from guava seeds. Peptides 2012, 37, 294-300. [CrossRef] [PubMed]

165. Park, C.J.; Park, C.B.; Hong, S.S.; Lee, H.S.; Lee, S.Y.; Kim, S.C. Characterization and cDNA cloning of two glycine- and histidinerich antimicrobial peptides from the roots of shepherd's purse, Capsella bursa-pastoris. Plant Mol. Biol. 2000, 44, $187-197$. [CrossRef] [PubMed]

166. Otvos, L. Antibacterial peptides isolated from insects. J. Pept. Sci. 2000, 6, 497-511. [CrossRef]

167. Tincu, J.A.; Taylor, S.W. Antimicrobial peptides from marine invertebrates. Antimicrob. Agents Chemother. 2004, 48, 3645-3654. [CrossRef] [PubMed]

168. Bulet, P.; Stöcklin, R.; Menin, L. Anti-microbial peptides: From invertebrates to vertebrates. Immunol. Rev. 2004, 198, 169-184. [CrossRef]

169. Shafee, T.M.A.; Lay, F.T.; Hulett, M.D.; Anderson, M.A. The Defensins Consist of Two Independent, Convergent Protein Superfamilies. Mol. Biol. Evol. 2016. [CrossRef]

170. Shafee, T.M.A.; Lay, F.T.; Phan, T.K.; Anderson, M.A.; Hulett, M.D. Convergent evolution of defensin sequence, structure and function. Cell. Mol. Life Sci. 2017, 74, 663-682. [CrossRef] [PubMed]

171. Tassanakajon, A.; Somboonwiwat, K.; Amparyup, P. Sequence diversity and evolution of antimicrobial peptides in invertebrates. Dev. Comp. Immunol. 2015, 48, 324-341. [CrossRef]

172. Froy, O. Convergent evolution of invertebrate defensins and nematode antibacterial factors. Trends Microbiol. 2005, 13, 314-319. [CrossRef] [PubMed]

173. Sperstad, S.V.; Haug, T.; Blencke, H.M.; Styrvold, O.B.; Li, C.; Stensvåg, K. Antimicrobial peptides from marine invertebrates: Challenges and perspectives in marine antimicrobial peptide discovery. Biotechnol. Adv. 2011, 29, 519-530. [CrossRef] [PubMed]

174. Cociancich, S.; Ghazi, A.; Hetru, C.; Hoffmann, J.A.; Letellier, L. Insect defensin, an inducible antibacterial peptide, forms voltage-dependent channels in Micrococcus luteus. J. Biol. Chem. 1993, 268, 19239-19245. [CrossRef]

175. Matsuyama, K.; Natori, S. Mode of action of sapecin, a novel antibacterial protein of Sarcophaga peregrina (flesh fly). J. Biochem. 1990, 108, 128-132. [CrossRef] [PubMed]

176. Yang, D.; Zhang, Q.; Wang, Q.; Chen, L.; Liu, Y.; Cong, M.; Wu, H.; Li, F.; Ji, C.; Zhao, J. A defensin-like antimicrobial peptide from the manila clam Ruditapes philippinarum: Investigation of the antibacterial activities and mode of action. Fish Shellfish Immunol. 2018, 80, 274-280. [CrossRef] [PubMed] 
177. Takeuchi, K.; Takahashi, H.; Sugai, M.; Iwai, H.; Kohno, T.; Sekimizu, K.; Natori, S.; Shimada, I. Channel-forming membrane permeabilization by an antibacterial protein, sapecin. Determination of membrane-buried and oligomerization surfaces by NMR J. Biol. Chem. 2004, 279, 4981-4987. [CrossRef] [PubMed]

178. Cornet, B.; Bonmatin, J.M.; Hetru, C.; Hoffmann, J.A.; Ptak, M.; Vovelle, F. Refined three-dimensional solution structure of insect defensin A. Structure 1995, 3, 435-448. [CrossRef]

179. Saito, T.; Kawabata, S.I.; Shigenaga, T.; Takayenoki, Y.; Cho, J.; Nakajima, H.; Hirata, M.; Iwanaga, S. A novel big defensin identified in horseshoe crab hemocytes: Isolation, amino acid sequence, and antibacterial activity. J. Biochem. 1995, 117, 1131-1137. [CrossRef] [PubMed]

180. Kawabata, S.I. Immunocompetent molecules and their response network in horseshoe crabs. Adv. Exp. Med. Biol. 2010, 708, 122-136. [CrossRef] [PubMed]

181. Zhao, J.; Song, L.; Li, C.; Ni, D.; Wu, L.; Zhu, L.; Wang, H.; Xu, W. Molecular cloning, expression of a big defensin gene from bay scallop Argopecten irradians and the antimicrobial activity of its recombinant protein. Mol. Immunol. 2007, 44, 360-368. [CrossRef] [PubMed]

182. Rosa, R.D.; Santini, A.; Fievet, J.; Bulet, P.; Destoumieux-Garzón, D.; Bachère, E. Big defensins, a diverse family of antimicrobial peptides that follows different patterns of expression in hemocytes of the oyster crassostrea gigas. PloS ONE 2011, 6. [CrossRef] [PubMed]

183. Gerdol, M.; De Moro, G.; Manfrin, C.; Venier, P.; Pallavicini, A. Big defensins and mytimacins, new AMP families of the Mediterranean mussel Mytilus galloprovincialis. Dev. Comp. Immunol. 2012, 36, 390-399. [CrossRef] [PubMed]

184. Pisuttharachai, D.; Yasuike, M.; Aono, H.; Yano, Y.; Murakami, K.; Kondo, H.; Aoki, T.; Hirono, I. Characterization of two isoforms of Japanese spiny lobster Panulirus japonicus defensin cDNA. Dev. Comp. Immunol. 2009, 33, 434-438. [CrossRef]

185. Montero-Alejo, V.; Acosta-Alba, J.; Perdomo-Morales, R.; Perera, E.; Hernández-Rodríguez, E.W.; Estrada, M.P.; Porto-Verdecia, M. Defensin like peptide from Panulirus argus relates structurally with beta defensin from vertebrates. Fish Shellfish Immunol. 2012, 33, 872-879. [CrossRef]

186. Cheng, T.; Zhao, P.; Liu, C.; Xu, P.; Gao, Z.; Xia, Q.; Xiang, Z. Structures, regulatory regions, and inductive expression patterns of antimicrobial peptide genes in the silkworm Bombyx mori. Genomics 2006, 87, 356-365. [CrossRef] [PubMed]

187. Gazit, E.; Shai, Y.; Lee, W.J.; Brey, P.T. Mode of Action of the Antibacterial Cecropin B2: A Spectrofluorometric Study. Biochemistry 1994, 33, 10681-10692. [CrossRef] [PubMed]

188. Gazit, E.; Miller, I.R.; Biggin, P.C.; Sansom, M.S.P.; Shai, Y. Structure and orientation of the mammalian antibacterial peptide cecropin P1 within phospholipid membranes. J. Mol. Biol. 1996, 258, 860-870. [CrossRef] [PubMed]

189. Lee, E.; Jeong, K.W.; Lee, J.; Shin, A.; Kim, J.K.; Lee, J.; Lee, D.G.; Kim, Y. Structure-activity relationships of cecropin-like peptides and their interactions with phospholipid membrane. BMB Rep. 2013, 46, 282-287. [CrossRef] [PubMed]

190. Moore, A.J.; Beazley, W.D.; Bibby, M.C.; Devine, D.A. Antimicrobial activity of cecropins. J. Antimicrob. Chemother. 1996, 37, 1077-1089. [CrossRef]

191. Hultmark, D.; Engström, Å.; Bennich, H.; Kapur, R.; Boman, H.G. Insect Immunity: Isolation and Structure of Cecropin D and Four Minor Antibacterial Components from Cecropia Pupae. Eur. J. Biochem. 1982, 127, 207-217. [CrossRef] [PubMed]

192. Ponnuvel, K.M.; Subhasri, N.; Sirigineedi, S.; Murthy, G.N.; Vijayaprakash, N.B. Molecular evolution of the cecropin multigene family in silkworm Bombyx mori. Bioinformation 2010, 5, 97-103. [CrossRef] [PubMed]

193. Efimova, S.S.; Schagina, L.V.; Ostroumova, O.S. Channel-forming activity of cecropins in lipid bilayers: Effect of agents modifying the membrane dipole potential. Langmuir 2014, 30, 7884-7892. [CrossRef] [PubMed]

194. Oñate-Garzón, J.; Manrique-Moreno, M.; Trier, S.; Leidy, C.; Torres, R.; Patiño, E. Antimicrobial activity and interactions of cationic peptides derived from Galleria mellonella cecropin D-like peptide with model membranes. J. Antibiot. 2017, 70, 238-245. [CrossRef] [PubMed]

195. Chen, H.M.; Chan, S.C.; Lee, J.C.; Chang, C.H.; Murugan, M.; Jack, R.W. Transmission Electron Microscopic Observations of Membrane Effects of Antibiotic Cecropin B on Escherichia coli. Microsc. Res. Tech. 2003, 62, 423-430. [CrossRef] [PubMed]

196. Ranganathan, S.; Simpson, K.J.; Shaw, D.C.; Nicholas, K.R. The whey acidic protein family: A new signature motif and threedimensional structure by comparative modeling. J. Mol. Graph. Model. 1999, 17, 106-113. [CrossRef]

197. Relf, J.M.; Chisholm, J.R.S.; Kemp, G.D.; Smith, V.J. Purification and characterization of a cysteine-rich 11.5-kDa antibacterial protein from the granular haemocytes of the shore crab, Carcinus maenas. Eur. J. Biochem. 1999, 264, 350-357. [CrossRef] [PubMed]

198. Smith, V.J.; Fernandes, J.M.O.; Kemp, G.D.; Hauton, C. Crustins: Enigmatic WAP domain-containing antibacterial proteins from crustaceans. Dev. Comp. Immunol. 2008, 32, 758-772. [CrossRef]

199. Smith, V.J. Phylogeny of whey acidic protein (WAP) four-disulfide core proteins and their role in lower vertebrates and invertebrates. Biochem. Soc. Trans. 2011, 39, 1403-1408. [CrossRef] [PubMed]

200. Christie, A.E.; Rus, S.; Goiney, C.C.; Smith, C.M.; Towle, D.W.; Dickinson, P.S. Identification and characterization of a cDNA encoding a crustin-like, putative antibacterial protein from the American lobster Homarus americanus. Mol. Immunol. 2007, 44, 3333-3337. [CrossRef] [PubMed]

201. Brockton, V.; Hammond, J.A.; Smith, V.J. Gene characterisation, isoforms and recombinant expression of carcinin, an antibacterial protein from the shore crab, Carcinus maenas. Mol. Immunol. 2007, 44, 943-949. [CrossRef] [PubMed] 
202. Jiravanichpaisal, P.; Lee, S.Y.; Kim, Y.A.; Andrén, T.; Söderhäll, I. Antibacterial peptides in hemocytes and hematopoietic tissue from freshwater crayfish Pacifastacus leniusculus: Characterization and expression pattern. Dev. Comp. Immunol. 2007, 31, 441-455. [CrossRef] [PubMed]

203. Amparyup, P.; Kondo, H.; Hirono, I.; Aoki, T.; Tassanakajon, A. Molecular cloning, genomic organization and recombinant expression of a crustin-like antimicrobial peptide from black tiger shrimp Penaeus monodon. Mol. Immunol. 2008, 45, 1085-1093. [CrossRef] [PubMed]

204. Krusong, K.; Poolpipat, P.; Supungul, P.; Tassanakajon, A. A comparative study of antimicrobial properties of crustinPm1 and crustinPm7 from the black tiger shrimp Penaeus monodon. Dev. Comp. Immunol. 2012, 36, 208-215. [CrossRef] [PubMed]

205. Zhang, Z.; Zhu, S. Comparative genomics analysis of five families of antimicrobial peptide-like genes in seven ant species. Dev. Comp. Immunol. 2012, 38, 262-274. [CrossRef] [PubMed]

206. Hancock, R.E.W.; Diamond, G. The role of cationic antimicrobial peptides in innate host defences. Trends Microbiol. 2000, 8 , 402-410. [CrossRef]

207. Avila, E.E. Functions of Antimicrobial Peptides in Vertebrates. Curr. Protein Pept. Sci. 2016, 18. [CrossRef] [PubMed]

208. Masso-Silva, J.A.; Diamond, G. Antimicrobial peptides from fish. Pharmaceuticals 2014, 7, 265-310. [CrossRef]

209. Shinnar, A.E.; Butler, K.L.; Park, H.J. Cathelicidin family of antimicrobial peptides: Proteolytic processing and protease resistance. Bioorg. Chem. 2003, 31, 425-436. [CrossRef]

210. Shinnar, A.; Uzzell, T.; Rao, M.; Spooner, E.; Lane, W.; Zasloff, M. New family of linear antimicrobial peptides from hagfish intestine contains bromo-tryptophan as novel amino acid; Peptides: Chemistry and Biology. In Proceedings of the 14th American Peptide Symposium, Columbus, OH, USA, 18-23 June 1995; Mayflower Scientific Ltd: Columbus, OH, USA, 1996; Volume 14, pp. 189-191.

211. Basañez, G.; Shinnar, A.E.; Zimmerberg, J. Interaction of hagfish cathelicidin antimicrobial peptides with model lipid membranes. FEBS Lett. 2002, 532, 115-120. [CrossRef]

212. Broekman, D.C.; Zenz, A.; Gudmundsdottir, B.K.; Lohner, K.; Maier, V.H.; Gudmundsson, G.H. Functional characterization of codCath, the mature cathelicidin antimicrobial peptide from Atlantic cod (Gadus morhua). Peptides 2011, 32, $2044-2051$. [CrossRef] [PubMed]

213. Chang, C.I.; Zhang, Y.A.; Zou, J.; Nie, P.; Secombes, C.J. Two cathelicidin genes are present in both rainbow trout (Oncorhynchus mykiss) and atlantic salmon (Salmo salar). Antimicrob. Agents Chemother. 2006, 50, 185-195. [CrossRef] [PubMed]

214. Chang, C.I.; Pleguezuelos, O.; Zhang, Y.A.; Zou, J.; Secombes, C.J. Identification of a novel cathelicidin gene in the rainbow trout, Oncorhynchus mykiss. Infect. Immun. 2005, 73, 5053-5064. [CrossRef] [PubMed]

215. Cuesta, A.; Meseguer, J.; Esteban, M.Á. Molecular and functional characterization of the gilthead seabream $\beta$-defensin demonstrate its chemotactic and antimicrobial activity. Mol. Immunol. 2011, 48, 1432-1438. [CrossRef] [PubMed]

216. Zou, J.; Mercier, C.; Koussounadis, A.; Secombes, C. Discovery of multiple beta-defensin like homologues in teleost fish. Mol. Immunol. 2007, 44, 638-647. [CrossRef]

217. Wang, G.; Li, J.; Zou, P.; Xie, H.; Huang, B.; Nie, P.; Chang, M. Expression pattern, promoter activity and bactericidal property of $\beta$-defensin from the mandarin fish Siniperca chuatsi. Fish Shellfish Immunol. 2012, 33, 522-531. [CrossRef] [PubMed]

218. Falco, A.; Chico, V.; Marroquí, L.; Perez, L.; Coll, J.M.; Estepa, A. Expression and antiviral activity of a $\beta$-defensin-like peptide identified in the rainbow trout (Oncorhynchus mykiss) EST sequences. Mol. Immunol. 2008, 45, 757-765. [CrossRef] [PubMed]

219. Casadei, E.; Wang, T.; Zou, J.; González Vecino, J.L.; Wadsworth, S.; Secombes, C.J. Characterization of three novel $\beta$-defensin antimicrobial peptides in rainbow trout (Oncorhynchus mykiss). Mol. Immunol. 2009, 46, 3358-3366. [CrossRef] [PubMed]

220. Nam, B.H.; Moon, J.Y.; Kim, Y.O.; Kong, H.J.; Kim, W.J.; Lee, S.J.; Kim, K.K. Multiple $\beta$-defensin isoforms identified in early developmental stages of the teleost Paralichthys olivaceus. Fish Shellfish Immunol. 2010, 28, 267-274. [CrossRef]

221. Guo, M.; Wei, J.; Huang, X.; Huang, Y.; Qin, Q. Antiviral effects of $\beta$-defensin derived from orange-spotted grouper (Epinephelus coioides). Fish Shellfish Immunol. 2012, 32, 828-838. [CrossRef]

222. Jin, J.Y.; Zhou, L.; Wang, Y.; Li, Z.; Zhao, J.G.; Zhang, Q.Y.; Gui, J.F. Antibacterial and antiviral roles of a fish $\beta$-defensin expressed both in pituitary and testis. PloS ONE 2010, 5. [CrossRef] [PubMed]

223. Ruangsri, J.; Kitani, Y.; Kiron, V.; Lokesh, J.; Brinchmann, M.F.; Karlsen, B.O.; Fernandes, J.M.O. A Novel Beta-Defensin Antimicrobial Peptide in Atlantic Cod with Stimulatory Effect on Phagocytic Activity. PloS ONE 2013, 8, e62302. [CrossRef] [PubMed]

224. Huang, P.H.; Chen, J.Y.; Kuo, C.M. Three different hepcidins from tilapia, Oreochromis mossambicus: Analysis of their expressions and biological functions. Mol. Immunol. 2007, 44, 1922-1934. [CrossRef] [PubMed]

225. Hunter, H.N.; Bruce Fulton, D.; Ganz, T.; Vogel, H.J. The solution structure of human hepcidin, a peptide hormone with antimicrobial activity that is involved in iron uptake and hereditary hemochromatosis. J. Biol. Chem. 2002, 277, 37597-37603. [CrossRef] [PubMed]

226. Xu, T.; Sun, Y.; Shi, G.; Wang, R. Miiuy croaker hepcidin gene and comparative analyses reveal evidence for positive selection. PloS ONE 2012, 7. [CrossRef] [PubMed]

227. Masso-Silva, J.; Diamond, G.; Macias-Rodriguez, M.; Ascencio, F. Genomic organization and tissue-specific expression of hepcidin in the pacific mutton hamlet, Alphestes immaculatus (Breder, 1936). Fish Shellfish Immunol. 2011, 31, 1297-1302. [CrossRef] [PubMed] 
228. Hilton, K.B.; Lambert, L.A. Molecular evolution and characterization of hepcidin gene products in vertebrates. Gene 2008, 415 , 40-48. [CrossRef] [PubMed]

229. Wang, Y.; Liu, X.; Ma, L.; Yu, Y.; Yu, H.; Mohammed, S.; Chu, G.; Mu, L.; Zhang, Q. Identification and characterization of a hepcidin from half-smooth tongue sole Cynoglossus semilaevis. Fish Shellfish Immunol. 2012, 33, 213-219. [CrossRef] [PubMed]

230. Cai, L.; Cai, J.J.; Liu, H.P.; Fan, D.Q.; Peng, H.; Wang, K.J. Recombinant medaka (Oryzias melastigmus) pro-hepcidin: Multifunctional characterization. Comp. Biochem. Physiol. B Biochem. Mol. Biol. 2012, 161, 140-147. [CrossRef] [PubMed]

231. Fernandes, J.M.O.; Ruangsri, J.; Kiron, V. Atlantic cod piscidin and its diversification through positive selection. PloS ONE 2010, 5. [CrossRef] [PubMed]

232. Raju, S.V.; Sarkar, P.; Kumar, P.; Arockiaraj, J. Piscidin, Fish Antimicrobial Peptide: Structure, Classification, Properties, Mechanism, Gene Regulation and Therapeutical Importance. Int. J. Pept. Res. Ther. 2021, 27, 91-107. [CrossRef]

233. Cole, A.M.; Weis, P.; Diamond, G. Isolation and characterization of pleurocidin, an antimicrobial peptide in the skin secretions of winter flounder. J. Biol. Chem. 1997, 272, 12008-12013. [CrossRef] [PubMed]

234. Wang, G.; Li, X.; Wang, Z. APD3: The antimicrobial peptide database as a tool for research and education. Nucleic Acids Res. 2016, 44, D1087-D1093. [CrossRef] [PubMed]

235. Xu, X.; Lai, R. The chemistry and biological activities of peptides from amphibian skin secretions. Chem. Rev. 2015, 115, 1760-1846. [CrossRef] [PubMed]

236. Mangoni, M.L.; Maisetta, G.; Di Luca, M.; Gaddi, L.M.H.; Esin, S.; Florio, W.; Brancatisano, F.L.; Barra, D.; Campa, M.; Batoni, G. Comparative analysis of the bactericidal activities of amphibian peptide analogues against multidrug-resistant nosocomial bacterial strains. Antimicrob. Agents Chemother. 2008, 52, 85-91. [CrossRef] [PubMed]

237. Simmaco, M.; Kreil, G.; Barra, D. Bombinins, antimicrobial peptides from Bombina species. Biochim. Biophys. Acta Biomembr. 2009, 1788, 1551-1555. [CrossRef]

238. Hale, J.D.F.; Hancock, R.E.W. Alternative mechanisms of action of cationic antimicrobial peptides on bacteria. Expert Rev. Anti. Infect. Ther. 2007, 5, 951-959. [CrossRef]

239. Cho, J.H.; Sung, B.H.; Kim, S.C. Buforins: Histone H2A-derived antimicrobial peptides from toad stomach. Biochim. Biophys. Acta Biomembr. 2009, 1788, 1564-1569. [CrossRef] [PubMed]

240. Chai, J.; Chen, X.; Ye, T.; Zeng, B.; Zeng, Q.; Wu, J.; Kascakova, B.; Martins, L.A.; Prudnikova, T.; Smatanova, I.K.; et al. Characterization and functional analysis of cathelicidin-mh, a novel frog-derived peptide with anti-septicemic properties. Elife 2021, 10. [CrossRef] [PubMed]

241. Chen, J.; Lin, Y.F.; Chen, J.H.; Chen, X.; Lin, Z.H. Molecular characterization of cathelicidin in tiger frog (Hoplobatrachus rugulosus): Antimicrobial activity and immunomodulatory activity. Comp. Biochem. Physiol. Part C Toxicol. Pharmacol. 2021, 247. [CrossRef] [PubMed]

242. Marcos, J.F.; Gandía, M.; Harries, E.; Carmona, L.; Muñoz, A. Antifungal peptides: Exploiting non-lytic mechanisms and cell penetration properties. ACS Symp. Ser. 2012, 1095, 337-357. [CrossRef]

243. Huang, L.; Chen, D.; Wang, L.; Lin, C.; Ma, C.; Xi, X.; Chen, T.; Shaw, C.; Zhou, M. Dermaseptin-PH: A novel peptide with antimicrobial and anticancer activities from the skin secretion of the south American orange-legged leaf frog, pithecopus (phyllomedusa) hypochondrialis. Molecules 2017, 22. [CrossRef] [PubMed]

244. Belmadani, A.; Semlali, A.; Rouabhia, M. Dermaseptin-S1 decreases Candida albicans growth, biofilm formation and the expression of hyphal wall protein 1 and aspartic protease genes. J. Appl. Microbiol. 2018, 125, 72-83. [CrossRef]

245. Luca, V.; Stringaro, A.; Colone, M.; Pini, A.; Mangoni, M.L. Esculentin(1-21), an amphibian skin membrane-active peptide with potent activity on both planktonic and biofilm cells of the bacterial pathogen Pseudomonas aeruginosa. Cell. Mol. Life Sci. 2013, 70, 2773-2786. [CrossRef] [PubMed]

246. Luca, V.; Olivi, M.; Di Grazia, A.; Palleschi, C.; Uccelletti, D.; Mangoni, M.L. Anti-Candida activity of 1-18 fragment of the frog skin peptide esculentin-1b: In vitro and in vivo studies in a Caenorhabditis elegans infection model. Cell. Mol. Life Sci. 2014, 71, 2535-2546. [CrossRef] [PubMed]

247. Conlon, J.M. A proposed nomenclature for antimicrobial peptides from frogs of the genus Leptodactylus. Peptides 2008, 29, 1631-1632. [CrossRef]

248. Oliveira, M.; Gomes-Alves, A.G.; Sousa, C.; Mirta Marani, M.; Plácido, A.; Vale, N.; Delerue-Matos, C.; Gameiro, P.; Kückelhaus, S.A.S.; Tomas, A.M.; et al. Ocellatin-PT antimicrobial peptides: High-resolution microscopy studies in antileishmania models and interactions with mimetic membrane systems. Biopolymers 2016, 873-886. [CrossRef] [PubMed]

249. Lai, R.; Zheng, Y.T.; Shen, J.H.; Liu, G.J.; Liu, H.; Lee, W.H.; Tang, S.Z.; Zhang, Y. Antimicrobial peptides from skin secretions of Chinese red belly toad Bombina maxima. Peptides 2002, 23, 427-435. [CrossRef]

250. Wang, T.; Zhang, J.; Shen, J.H.; Jin, Y.; Lee, W.H.; Zhang, Y. Maximins S, a novel group of antimicrobial peptides from toad Bombina maxima. Biochem. Biophys. Res. Commun. 2005, 327, 945-951. [CrossRef] [PubMed]

251. Kim, M.K.; Kang, N.; Ko, S.J.; Park, J.; Park, E.; Shin, D.W.; Kim, S.H.; Lee, S.A.; Lee, J.I.; Lee, S.H.; et al. Antibacterial and antibiofilm activity and mode of action of magainin 2 against drug-resistant acinetobacter baumannii. Int. J. Mol. Sci. 2018, 19. [CrossRef] [PubMed]

252. Lehmann, J.; Retz, M.; Sidhu, S.S.; Suttmann, H.; Sell, M.; Paulsen, F.; Harder, J.; Unteregger, G.; Stöckle, M. Antitumor Activity of the Antimicrobial Peptide Magainin II against Bladder Cancer Cell Lines. Eur. Urol. 2006, 50, 141-147. [CrossRef] [PubMed] 
253. Park, Y.; Lee, D.G.; Hahm, K.S. HP(2-9)-magainin 2(1-12), a synthetic hybrid peptide, exerts its antifungal effect on Candida albicans by damaging the plasma membrane. J. Pept. Sci. 2004, 10, 204-209. [CrossRef] [PubMed]

254. Amiche, M.; Ladram, A.; Nicolas, P. A consistent nomenclature of antimicrobial peptides isolated from frogs of the subfamily Phyllomedusinae. Peptides 2008, 29, 2074-2082. [CrossRef] [PubMed]

255. El Amri, C.; Lacombe, C.; Zimmerman, K.; Ladram, A.; Amiche, M.; Nicolas, P.; Bruston, F. The plasticins: Membrane adsorption, lipid disorders, and biological activity. Biochemistry 2006, 45, 14285-14297. [CrossRef] [PubMed]

256. Cardoso, M.H. Insights into the Antimicrobial Activities of Unusual Antimicrobial Peptide Families from Amphibian Skin. J. Clin. Toxicol. 2014, 4. [CrossRef]

257. Basir, Y.J.; Knoop, F.C.; Dulka, J.; Conlon, J.M. Multiple antimicrobial peptides and peptides related to bradykinin and neuromedin $\mathrm{N}$ isolated from skin secretions of the pickerel frog, Rana palustris. Biochim. Biophys. Acta Protein Struct. Mol. Enzymol. 2000, 1543, 95-105. [CrossRef]

258. Pierre, T.N.; Seon, A.A.; Amiche, M.; Nicolas, P. Phylloxin, a novel peptide antibiotic of the dermaseptin family of antimicrobial/opioid peptide precursors. Eur. J. Biochem. 2000, 267, 370-378. [CrossRef] [PubMed]

259. Pinto, E.G.; Pimenta, D.C.; Antoniazzi, M.M.; Jared, C.; Tempone, A.G. Antimicrobial peptides isolated from Phyllomedusa nordestina (Amphibia) alter the permeability of plasma membrane of Leishmania and Trypanosoma cruzi. Exp. Parasitol. 2013, 135, 655-660. [CrossRef] [PubMed]

260. Liu, J.; Wu, Q.; Li, L.; Xi, X.; Wu, D.; Zhou, M.; Chen, T.; Shaw, C.; Wang, L. Discovery of phylloseptins that defense against grampositive bacteria and inhibit the proliferation of the non-small cell lung cancer cell line, from the skin secretions of phyllomedusa frogs. Molecules 2017, 22, 1428. [CrossRef] [PubMed]

261. Olson, L.; Soto, A.M.; Knoop, F.C.; Conlon, J.M. Pseudin-2: An antimicrobial peptide with low hemolytic activity from the skin of the paradoxical frog. Biochem. Biophys. Res. Commun. 2001, 288, 1001-1005. [CrossRef] [PubMed]

262. Park, S.C.; Kim, H.; Kim, J.Y.; Kim, H.; Cheong, G.W.; Lee, J.R.; Jang, M.K. Improved cell selectivity of pseudin-2 via substitution in the leucine-zipper motif: In vitro and in vivo antifungal activity. Antibiotics 2020, 9, 921. [CrossRef] [PubMed]

263. Chen, X.; Zhang, L.; Ma, C.; Zhang, Y.; Xi, X.; Wang, L.; Zhou, M.; Burrows, J.F.; Chen, T. A novel antimicrobial peptide, Ranatuerin-2PLx, showing therapeutic potential in inhibiting proliferation of cancer cells. Biosci. Rep. 2018, 38. [CrossRef] [PubMed]

264. Clark, D.P.; Durell, S.; Maloy, W.L.; Zasloff, M. Renalexin. A novel antimicrobial peptide from bullfrog (Rana catesbeiana) skin, structurally related to the bacterial antibiotic, polymyxin. J. Biol. Chem. 1994, 269, 10849-10855. [CrossRef]

265. Domhan, C.; Uhl, P.; Meinhardt, A.; Zimmermann, S.; Kleist, C.; Lindner, T.; Leotta, K.; Mier, W.; Wink, M. A novel tool against multiresistant bacterial pathogens: Lipopeptide modification of the natural antimicrobial peptide ranalexin for enhanced antimicrobial activity and improved pharmacokinetics. Int. J. Antimicrob. Agents 2018, 52, 52-62. [CrossRef] [PubMed]

266. van Hoek, M.L. Antimicrobial peptides in reptiles. Pharmaceuticals 2014, 7, 723-753. [CrossRef] [PubMed]

267. Cheng, Y.; Prickett, M.D.; Gutowska, W.; Kuo, R.; Belov, K.; Burt, D.W. Evolution of the avian $\beta$-defensin and cathelicidin genes. BMC Evol. Biol. 2015, 15, 188. [CrossRef] [PubMed]

268. Zhao, H.; Gan, T.X.; Liu, X.D.; Jin, Y.; Lee, W.H.; Shen, J.H.; Zhang, Y. Identification and characterization of novel reptile cathelicidins from elapid snakes. Peptides 2008, 29, 1685-1691. [CrossRef] [PubMed]

269. Wang, Y.; Hong, J.; Liu, X.; Yang, H.; Liu, R.; Wu, J.; Wang, A.; Lin, D.; Lai, R. Snake cathelicidin from Bungarus fasciatus is a potent peptide antibiotics. PloS ONE 2008, 3, e3217. [CrossRef] [PubMed]

270. Nair, D.G.; Fry, B.G.; Alewood, P.; Kumar, P.P.; Kini, R.M. Antimicrobial activity of omwaprin, a new member of the waprin family of snake venom proteins. Biochem. J. 2007, 402, 93-104. [CrossRef] [PubMed]

271. Evans, E.W.; Beach, G.G.; Wunderlich, J.; Harmon, B.G. Isolation of antimicrobial peptides from avian heterophils. J. Leukoc. Biol. 1994, 56, 661-665. [CrossRef] [PubMed]

272. Xiao, Y.; Cai, Y.; Bommineni, Y.R.; Fernando, S.C.; Prakash, O.; Gilliland, S.E.; Zhang, G. Identification and functional characterization of three chicken cathelicidins with potent antimicrobial activity. J. Biol. Chem. 2006, 281, 2858-2867. [CrossRef] [PubMed]

273. Xiao, Y.; Herrera, A.I.; Bommineni, Y.R.; Soulages, J.L.; Prakash, O.; Zhang, G. The central kink region of fowlicidin-2, an $\alpha$-helical host defense peptide, is critically involved in bacterial killing and endotoxin neutralization. J. Innate Immun. 2009, 1, 268-280. [CrossRef] [PubMed]

274. Qu, P.; Gao, W.; Chen, H.; Li, D.; Yang, N.; Zhu, J.; Feng, X.; Liu, C.; Li, Z. The central hinge link truncation of the antimicrobial peptide fowlicidin-3 enhances its cell selectivity without antibacterial activity loss. Antimicrob. Agents Chemother. 2016, 60, 2798-2806. [CrossRef] [PubMed]

275. Goitsuka, R.; Chen, C.L.H.; Benyon, L.; Asano, Y.; Kitamura, D.; Cooper, M.D. Chicken cathelicidin-B1, an antimicrobial guardian at the mucosal M cell gateway. Proc. Natl. Acad. Sci. USA 2007, 104, 15063-15068. [CrossRef] [PubMed]

276. Feng, F.; Chen, C.; Zhu, W.; He, W.; Guang, H.; Li, Z.; Wang, D.; Liu, J.; Chen, M.; Wang, Y.; et al. Gene cloning, expression and characterization of avian cathelicidin orthologs, Cc-CATHs, from Coturnix coturnix. FEBS J. 2011, 278, 1573-1584. [CrossRef] [PubMed]

277. Ishige, T.; Hara, H.; Hirano, T.; Kono, T.; Hanzawa, K. Characterization of the cathelicidin cluster in the Japanese quail (Coturnix japonica). Anim. Sci. J. 2017, 88, 1249-1257. [CrossRef] [PubMed] 
278. Yu, H.; Lu, Y.; Qiao, X.; Wei, L.; Fu, T.; Cai, S.; Wang, C.; Liu, X.; Zhong, S.; Wang, Y. Novel Cathelicidins from Pigeon Highlights Evolutionary Convergence in Avain Cathelicidins and Functions in Modulation of Innate Immunity. Sci. Rep. 2015, 5. [CrossRef] [PubMed]

279. Gao, W.; Xing, L.; Qu, P.; Tan, T.; Yang, N.; Li, D.; Chen, H.; Feng, X. Identification of a novel cathelicidin antimicrobial peptide from ducks and determination of its functional activity and antibacterial mechanism. Sci. Rep. 2015, 5. [CrossRef] [PubMed]

280. Wang, Y.; Lu, Z.; Feng, F.; Zhu, W.; Guang, H.; Liu, J.; He, W.; Chi, L.; Li, Z.; Yu, H. Molecular cloning and characterization of novel cathelicidin-derived myeloid antimicrobial peptide from Phasianus colchicus. Dev. Comp. Immunol. 2011, 35, 314-322. [CrossRef]

281. Yacoub, H.A.; Elazzazy, A.M.; Mahmoud, M.M.; Baeshen, M.N.; Al-Maghrabi, O.A.; Alkarim, S.; Ahmed, E.S.; Almehdar, H.A.; Uversky, V.N. Chicken cathelicidins as potent intrinsically disordered biocides with antimicrobial activity against infectious pathogens. Dev. Comp. Immunol. 2016, 65, 8-24. [CrossRef] [PubMed]

282. Hamad, S.K.; Kim, S.; El-Kadi, S.W.; Wong, E.A.; Dalloul, R.A. Comparative expression of host defense peptides in turkey poults. Poult. Sci. 2017, 96, 2083-2090. [CrossRef] [PubMed]

283. Stegemann, C.; Kolobov, A.; Leonova, Y.F.; Knappe, D.; Shamova, O.; Ovchinnikova, T.V.; Kokryakov, V.N.; Hoffmann, R. Isolation, purification and de novo sequencing of TBD-1, the first beta-defensin from leukocytes of reptiles. Proteomics 2009, 9, 1364-1373. [CrossRef] [PubMed]

284. Yount, N.Y.; Kupferwasser, D.; Spisni, A.; Dutz, S.M.; Ramjan, Z.H.; Sharma, S.; Waring, A.J.; Yeaman, M.R. Selective reciprocity in antimicrobial activity versus cytotoxicity of hBD-2 and crotamine. Proc. Natl. Acad. Sci. USA 2009, 106, 14972-14977. [CrossRef] [PubMed]

285. Lakshminarayanan, R.; Vivekanandan, S.; Samy, R.P.; Banerjee, Y.; Chi-Jin, E.O.; Kay, W.T.; Jois, S.D.S.; Kini, R.M.; Valiyaveettil, S. Structure, self-assembly, and dual role of a $\beta$-defensin-like peptide from the Chinese soft-shelled turtle eggshell matrix. J. Am. Chem. Soc. 2008, 130, 4660-4668. [CrossRef] [PubMed]

286. Chattopadhyay, S.; Sinha, N.K.; Banerjee, S.; Roy, D.; Chattopadhyay, D.; Roy, S. Small cationic protein from a marine turtle has $\beta$-defensin-like fold and antibacterial and antiviral activity. Proteins Struct. Funct. Genet. 2006, 64, 524-531. [CrossRef]

287. van Dijk, A.; Veldhuizen, E.J.A.; Haagsman, H.P. Avian defensins. Vet. Immunol. Immunopathol. 2008, 124, 1-18. [CrossRef] [PubMed]

288. Sugiarto, H.; Yu, P.L. Identification of three novel ostricacins: An update on the phylogenetic perspective of $\beta$-defensins. Int. J. Antimicrob. Agents 2006, 27, 229-235. [CrossRef]

289. Sugiarto, H.; Yu, P.L. Avian antimicrobial peptides: The defense role of $\beta$-defensins. Biochem. Biophys. Res. Commun. 2004, 323, 721-727. [CrossRef] [PubMed]

290. Zhao, C.; Nguyen, T.; Liu, L.; Sacco, R.E.; Brogden, K.A.; Lehrer, R.I. Gallinacin-3, an inducible epithelial $\beta$-defensin in the chicken. Infect. Immun. 2001, 69, 2684-2691. [CrossRef] [PubMed]

291. Thouzeau, C.; Le Maho, Y.; Froget, G.; Sabatier, L.; Le Bohec, C.; Hoffmann, J.A.; Bulet, P. Spheniscins, Avian $\beta$-Defensins in Preserved Stomach Contents of the King Penguin, Aptenodytes patagonicus. J. Biol. Chem. 2003, 278, 51053-51058. [CrossRef] [PubMed]

292. Ageitos, J.M.; Sánchez-Pérez, A.; Calo-Mata, P.; Villa, T.G. Antimicrobial peptides (AMPs): Ancient compounds that represent novel weapons in the fight against bacteria. Biochem. Pharmacol. 2017, 133, 117-138. [CrossRef] [PubMed]

293. Tomasinsig, L.; Zanetti, M. The Cathelicidins-Structure, Function and Evolution. Curr. Protein Pept. Sci. 2005, 6, 23-34. [CrossRef] [PubMed]

294. Kościuczuk, E.M.; Lisowski, P.; Jarczak, J.; Strzałkowska, N.; Jóźwik, A.; Horbańczuk, J.; Krzyżewski, J.; Zwierzchowski, L.; Bagnicka, E. Cathelicidins: Family of antimicrobial peptides. A review. Mol. Biol. Rep. 2012, 39, 10957-10970. [CrossRef] [PubMed]

295. Duplantier, A.J.; van Hoek, M.L. The human cathelicidin antimicrobial peptide LL-37 as a potential treatment for polymicrobial infected wounds. Front. Immunol. 2013, 4, 143. [CrossRef] [PubMed]

296. Dean, S.N.; Bishop, B.M.; Van Hoek, M.L. Susceptibility of Pseudomonas aeruginosa biofilm to alpha-helical peptides: Denantiomer of LL-37. Front. Microbiol. 2011, 2. [CrossRef] [PubMed]

297. Dean, S.N.; Bishop, B.M.; van Hoek, M.L. Natural and synthetic cathelicidin peptides with anti-microbial and anti-biofilm activity against Staphylococcus aureus. BMC Microbiol. 2011, 11, 114. [CrossRef] [PubMed]

298. Overhage, J.; Campisano, A.; Bains, M.; Torfs, E.C.W.; Rehm, B.H.A.; Hancock, R.E.W. Human host defense peptide LL-37 prevents bacterial biofilm formation. Infect. Immun. 2008, 76, 4176-4182. [CrossRef] [PubMed]

299. Sochacki, K.A.; Barns, K.J.; Bucki, R.; Weisshaar, J.C. Real-time attack on single Escherichia coli cells by the human antimicrobial peptide LL-37. Proc. Natl. Acad. Sci. USA 2011, 108. [CrossRef] [PubMed]

300. Barns, K.J.; Weisshaar, J.C. Real-time attack of LL-37 on single Bacillus subtilis cells. Biochim. Biophys. Acta Biomembr. 2013, 1828, 1511-1520. [CrossRef] [PubMed]

301. Neville, F.; Hodges, C.S.; Liu, C.; Konovalov, O.; Gidalevitz, D. In situ characterization of lipid A interaction with antimicrobial peptides using surface X-ray scattering. Biochim. Biophys. Acta Biomembr. 2006, 1758, 232-240. [CrossRef]

302. Henzler-Wildman, K.A.; Martinez, G.V.; Brown, M.F.; Ramamoorthy, A. Perturbation of the hydrophobic core of lipid bilayers by the human antimicrobial peptide LL-37. Biochemistry 2004, 43, 8459-8469. [CrossRef] [PubMed] 
303. Brahma, B.; Patra, M.C.; Karri, S.; Chopra, M.; Mishra, P.; De, B.C.; Kumar, S.; Mahanty, S.; Thakur, K.; Poluri, K.M.; et al. Diversity, antimicrobial action and structure- activity relationship of buffalo cathelicidins. PloS ONE 2015, 10, e0144741. [CrossRef] [PubMed]

304. Hsu, C.H.; Chen, C.; Jou, M.L.; Lee, A.Y.L.; Lin, Y.C.; Yu, Y.P.; Huang, W.T.; Wu, S.H. Structural and DNA-binding studies on the bovine antimicrobial peptide, indolicidin: Evidence for multiple conformations involved in binding to membranes and DNA. Nucleic Acids Res. 2005, 33, 4053-4064. [CrossRef] [PubMed]

305. Kokryakov, V.N.; Harwig, S.S.L.; Panyutich, E.A.; Shevchenko, A.A.; Aleshina, G.M.; Shamova, O.V.; Korneva, H.A.; Lehrer, R.I. Protegrins: Leukocyte antimicrobial peptides that combine features of corticostatic defensins and tachyplesins. FEBS Lett. 1993, 327, 231-236. [CrossRef]

306. Zhao, C.; Liu, L.; Lehrer, R.I. Identification of a new member of the protegrin family by cDNA cloning. FEBS Lett. 1994, 346, 285-288. [CrossRef] [PubMed]

307. Zhao, C.; Ganz, T.; Lehrer, R.I. The structure of porcine protegrin genes. FEBS Lett. 1995, 368, 197-202. [CrossRef]

308. Steinberg, D.A.; Hurst, M.A.; Fujii, C.A.; Kung, A.H.C.; Ho, J.F.; Cheng, F.C.; Loury, D.J.; Fiddes, J.C. Protegrin-1: A broadspectrum, rapidly microbicidal peptide with in vivo activity. Antimicrob. Agents Chemother. 1997, 41, 1738-1742. [CrossRef] [PubMed]

309. Gour, S.; Kumar, V.; Singh, A.; Gadhave, K.; Goyal, P.; Pandey, J.; Giri, R.; Yadav, J.K. Mammalian antimicrobial peptide protegrin-4 self assembles and forms amyloid-like aggregates: Assessment of its functional relevance. J. Pept. Sci. 2019, 25. [CrossRef] [PubMed]

310. Brogden, K.A.; Ackermann, M.; McCray, P.B.; Tack, B.F. Antimicrobial peptides in animals and their role in host defences. Int. J. Antimicrob. Agents 2003, 22, 465-478. [CrossRef]

311. Radermacher, S.W.; Schoop, V.M.; Schluesener, H.J. Bactenecin, a leukocytic antimicrobial peptide, is cytotoxic to neuronal and glial cells. J. Neurosci. Res. 1993, 36, 657-662. [CrossRef] [PubMed]

312. Skerlavaj, B.; Romeo, D.; Gennaro, R. Rapid membrane permeabilization and inhibition of vital functions of gram-negative bacteria by bactenecins. Infect. Immun. 1990, 58, 3724-3730. [CrossRef] [PubMed]

313. Skerlavaj, B.; Scocchi, M.; Gennaro, R.; Risso, A.; Zanetti, M. Structural and functional analysis of horse cathelicidin peptides Antimicrob. Agents Chemother. 2001, 45, 715-722. [CrossRef] [PubMed]

314. Selsted, M.E.; Ouellette, A.J. Mammalian defensins in the antimicrobial immune response. Nat. Immunol. 2005, 6, 551-557. [CrossRef]

315. Ayabe, T.; Satchell, D.P.; Wilson, C.L.; Parks, W.C.; Selsted, M.E.; Ouellette, A.J. Secretion of microbicidal $\alpha$-defensins by intestinal Paneth cells in response to bacteria. Nat. Immunol. 2000, 1, 113-118. [CrossRef] [PubMed]

316. Yamashita, T.; Saito, K. Purification, primary structure, and biological activity of guinea pig neutrophil cationic peptides. Infect. Immun. 1989, 57, 2405-2409. [CrossRef] [PubMed]

317. Selsted, M.E.; Szklarek, D.; Lehrer, R.I. Purification and antibacterial activity of antimicrobial peptides of rabbit granulocytes. Infect. Immun. 1984, 45, 150-154. [CrossRef]

318. Ganz, T.; Selsted, M.E.; Szklarek, D.; Harwig, S.S.; Daher, K.; Bainton, D.F.; Lehrer, R.I. Defensins. Natural peptide antibiotics of human neutrophils. J. Clin. Invest. 1985, 76, 1427-1435. [CrossRef] [PubMed]

319. Wilde, C.G.; Griffith, J.E.; Marra, M.N.; Snable, J.L.; Scott, R.W. Purification and characterization of human neutrophil peptide 4, a novel member of the defensin family. J. Biol. Chem. 1989, 264, 11200-11203. [CrossRef]

320. Jones, D.E.; Bevins, C.L. Paneth cells of the human small intestine express an antimicrobial peptide gene. J. Biol. Chem. 1992, 267, 23216-23225. [CrossRef]

321. Jones, D.E.; Bevins, C.L. Defensin- 6 mRNA in human Paneth cells: Implications for antimicrobial peptides in host defense of the human bowel. FEBS Lett. 1993, 315, 187-192. [CrossRef]

322. Ehmann, D.; Wendler, J.; Koeninger, L.; Larsen, I.S.; Klag, T.; Berger, J.; Marette, A.; Schaller, M.; Stange, E.F.; Malek, N.P.; et al. Paneth cell $\alpha$-defensins HD-5 and HD-6 display differential degradation into active antimicrobial fragments. Proc. Natl. Acad. Sci. USA 2019, 116, 3746-3751. [CrossRef] [PubMed]

323. De Smet, K.; Contreras, R. Human antimicrobial peptides: Defensins, cathelicidins and histatins. Biotechnol. Lett. 2005, 27, 1337-1347. [CrossRef] [PubMed]

324. Lehrer, R.I.; Barton, A.; Daher, K.A.; Harwig, S.S.L.; Ganz, T.; Selsted, M.E. Interaction of human defensins with Escherichia coli. Mechanism of bactericidal activity. J. Clin. Invest. 1989, 84, 553-561. [CrossRef] [PubMed]

325. Schneider, J.J.; Unholzer, A.; Schaller, M.; Schäfer-Korting, M.; Korting, H.C. Human defensins. J. Mol. Med. 2005, 83, 587-595. [CrossRef] [PubMed]

326. Diamond, G.; Zasloff, M.; Eck, H.; Brasseur, M.; Lee Maloy, W.; Bevins, C.L. Tracheal antimicrobial peptide, a cysteine-rich peptide from mammalian tracheal mucosa: Peptide isolation and cloning of a cDNA. Proc. Natl. Acad. Sci. USA 1991, 88, 3952-3956. [CrossRef] [PubMed]

327. Schonwetter, B.S.; Stolzenberg, E.D.; Zasloff, M.A. Epithelial antibiotics induced at sites of inflammation. Science 1995, 267, 1645-1648. [CrossRef] [PubMed]

328. Rieg, S.; Meier, B.; Fähnrich, E.; Huth, A.; Wagner, D.; Kern, W.V.; Kalbacher, H. Differential activity of innate defense antimicrobial peptides against Nocardia species. BMC Microbiol. 2010, 10, 1-10. [CrossRef] [PubMed] 
329. Selsted, M.E.; Tang, Y.Q.; Morris, W.L.; McGuire, P.A.; Novotny, M.J.; Smith, W.; Henschen, A.H.; Cullor, J.S. Purification, primary structures, and antibacterial activities of $\beta$-defensins, a new family of antimicrobial peptides from bovine neutrophils. J. Biol. Chem. 1993, 268, 6641-6648. [CrossRef]

330. Pazgier, M.; Hoover, D.M.; Yang, D.; Lu, W.; Lubkowski, J. Human $\beta$-defensins. Cell. Mol. Life Sci. 2006, 63, 1294-1313. [CrossRef] [PubMed]

331. McCray, P.B.; Bentley, L. Human Airway Epithelia Express a $\beta$-defensin. Am. J. Respir. Cell Mol. Biol. 1997, 16, 343-349. [CrossRef] [PubMed]

332. Frye, M. 186. Differential expression of human \$alpha;- and \$beta;-defensins mRNA in gastrointestinal epithelia. Neth. J. Med. 1999, 54, S71. [CrossRef]

333. Valore, E.V.; Park, C.H.; Quayle, A.J.; Wiles, K.R.; McCray, P.B.; Ganz, T. Human $\beta$-defensin-1: An antimicrobial peptide of urogenital tissues. J. Clin. Invest. 1998, 101, 1633-1642. [CrossRef] [PubMed]

334. García, J.-R.C.; Krause, A.; Schulz, S.; Rodríguez-Jiménez, F.-J.; Klüver, E.; Adermann, K.; Forssmann, U.; Frimpong-Boateng, A.; Bals, R.; Forssmann, W.-G. Human $\beta$-defensin 4: A novel inducible peptide with a specific salt-sensitive spectrum of antimicrobial activity. FASEB J. 2001, 15, 1819-1821. [CrossRef] [PubMed]

335. Harder, J.; Meyer-Hoffert, U.; Wehkamp, K.; Schwichtenberg, L.; Schröder, J.M. Differential gene induction of human $\beta$-defensins (hBD-1, -2, -3, and -4) in keratinocytes is inhibited by retinoic acid. J. Invest. Dermatol. 2004, 123, 522-529. [CrossRef]

336. Nguyen, T.X.; Cole, A.M.; Lehrer, R.I. Evolution of primate $\theta$-defensins: A serpentine path to a sweet tooth. Peptides 2003, 24, 1647-1654. [CrossRef] [PubMed]

337. Hazlett, L.; Wu, M. Defensins in innate immunity. Cell Tissue Res. 2011, 343, 175-188. [CrossRef] [PubMed]

338. Wilmes, M.; Stockem, M.; Bierbaum, G.; Schlag, M.; Götz, F.; Tran, D.Q.; Schaal, J.B.; Ouellette, A.J.; Selsted, M.E.; Sahl, H.G. Killing of staphylococci by $\theta$-defensins involves membrane impairment and activation of autolytic enzymes. Antibiotics 2014, 3, 617-631. [CrossRef] [PubMed]

339. Welkos, S.; Cote, C.K.; Hahn, U.; Shastak, O.; Jedermann, J.; Bozue, J.; Jung, G.; Ruchala, P.; Pratikhya, P.; Tang, T.; et al. Humanized $\theta$-defensins (retrocyclins) enhance macrophage performance and protect mice from experimental anthrax infections. Antimicrob. Agents Chemother. 2011, 55, 4238-4250. [CrossRef] [PubMed]

340. Basso, V.; Garcia, A.; Tran, D.Q.; Schaal, J.B.; Tran, P.; Ngole, D.; Aqeel, Y.; Tongaonkar, P.; Ouellette, A.J.; Selsteda, M.E. Fungicidal Potency and Mechanisms of -Defensins against Multidrug-Resistant Candida Species. Antimicrob. Agents Chemother. 2018, 62. [CrossRef] [PubMed]

341. Maróti Gergely, G.; Kereszt, A.; Kondorosi, É.; Mergaert, P. Natural roles of antimicrobial peptides in microbes, plants and animals. Res. Microbiol. 2011, 162, 363-374. [CrossRef] [PubMed]

342. Miao, J.; Guo, H.; Chen, F.; Zhao, L.; He, L.; Ou, Y.; Huang, M.; Zhang, Y.; Guo, B.; Cao, Y.; et al. Antibacterial Effects of a Cell-Penetrating Peptide Isolated from Kefir. J. Agric. Food Chem. 2016, 64, 3234-3242. [CrossRef] [PubMed]

343. Tareq, F.S.; Lee, M.A.; Lee, H.S.; Lee, Y.J.; Lee, J.S.; Hasan, C.M.; Islam, M.T.; Shin, H.J. Gageotetrins A-C, noncytotoxic antimicrobial linear lipopeptides from a marine bacterium bacillus subtilis. Org. Lett. 2014, 16, 928-931. [CrossRef] [PubMed]

344. Liu, Z.; Brady, A.; Young, A.; Rasimick, B.; Chen, K.; Zhou, C.; Kallenbach, N.R. Length effects in antimicrobial peptides of the (RW)n series. Antimicrob. Agents Chemother. 2007, 51, 597-603. [CrossRef] [PubMed]

345. Ringstad, L.; Schmidtchen, A.; Malmsten, M. Effect of peptide length on the interaction between consensus peptides and DOPC/DOPA bilayers. Langmuir 2006, 22, 5042-5050. [CrossRef] [PubMed]

346. Deslouches, B.; Phadke, S.M.; Lazarevic, V.; Cascio, M.; Islam, K.; Montelaro, R.C.; Mietzner, T.A. De novo generation of cationic antimicrobial peptides: Influence of length and tryptophan substitution on antimicrobial activity. Antimicrob. Agents Chemother. 2005, 49, 316-322. [CrossRef] [PubMed]

347. Kumar, P.; Kizhakkedathu, J.N.; Straus, S.K. Antimicrobial peptides: Diversity, mechanism of action and strategies to improve the activity and biocompatibility in vivo. Biomolecules 2018, 8, 4. [CrossRef] [PubMed]

348. Silhavy, T.J.; Kahne, D.; Walker, S. The bacterial cell envelope. Cold Spring Harb. Perspect. Biol. 2010, 2. [CrossRef] [PubMed]

349. Wu, M.; Maier, E.; Benz, R.; Hancock, R.E.W. Mechanism of interaction of different classes of cationic antimicrobial peptides with planar bilayers and with the cytoplasmic membrane of Escherichia coli. Biochemistry 1999, 38, 7235-7242. [CrossRef] [PubMed]

350. Bechinger, B. Detergent-like properties of magainin antibiotic peptides: A 31P solid-state NMR spectroscopy study. Biochim. Biophys. Acta Biomembr. 2005, 1712, 101-108. [CrossRef] [PubMed]

351. Pouny, Y.; Rapaport, D.; Shai, Y.; Mor, A.; Nicolas, P. Interaction of Antimicrobial Dermaseptin and its Fluorescently Labeled Analogs with Phospholipid Membranes. Biochemistry 1992, 31, 12416-12423. [CrossRef] [PubMed]

352. Shimazaki, K.; Tazume, T.; Uji, K.; Tanaka, M.; Kumura, H.; Mikawa, K.; Shimo-Oka, T. Properties of a Heparin-binding Peptide Derived from Bovine Lactoferrin. J. Dairy Sci. 1998, 81, 2841-2849. [CrossRef]

353. Fernandes, J.M.O.; Molle, G.; Kemp, G.D.; Smith, V.J. Isolation and characterisation of oncorhyncin II, a histone H1-derived antimicrobial peptide from skin secretions of rainbow trout, Oncorhynchus mykiss. Dev. Comp. Immunol. 2004, 28, 127-138. [CrossRef]

354. Anderson, R.C.; Yu, P.L. Isolation and characterisation of proline/arginine-rich cathelicidin peptides from ovine neutrophils. Biochem. Biophys. Res. Commun. 2003, 312, 1139-1146. [CrossRef]

355. Taylor, S.W.; Sun, C.; Hsieh, A.; Andon, N.L.; Ghosh, S.S. A sulfated, phosphorylated 7 kDa secreted peptide characterized by direct analysis of cell culture media. J. Proteome Res. 2008, 7, 795-802. [CrossRef] [PubMed] 
356. Baltz, R.H.; Miao, V.; Wrigley, S.K. Natural products to drugs: Daptomycin and related lipopeptide antibiotics. Nat. Prod. Rep. 2005, 22, 717-741. [CrossRef] [PubMed]

357. Paulmann, M.; Arnold, T.; Linke, D.; Özdirekcan, S.; Kopp, A.; Gutsmann, T.; Kalbacher, H.; Wanke, I.; Schuenemann, V.J.; Habeck, M.; et al. Structure-activity analysis of the dermcidin-derived peptide DCD-1L, an anionic antimicrobial peptide present in human sweat. J. Biol. Chem. 2012, 287, 8434-8443. [CrossRef] [PubMed]

358. Steffen, H.; Rieg, S.; Wiedemann, I.; Kalbacher, H.; Deeg, M.; Sahl, H.G.; Peschel, A.; Götz, F.; Garbe, C.; Schittek, B. Naturally processed dermcidin-derived peptides do not permeabilize bacterial membranes and kill microorganisms irrespective of their charge. Antimicrob. Agents Chemother. 2006, 50, 2608-2620. [CrossRef] [PubMed]

359. Kyte, J.; Doolittle, R.F. A simple method for displaying the hydropathic character of a protein. J. Mol. Biol. 1982, 157, 105-132. [CrossRef]

360. Wang, G. Antimicrobial peptides: Discovery, design, and novel therapeutic strategies. In Antimicrobial Peptides: Discovery, Design and Novel Therapeutic Strategies; Cabi: Wallingford, UK, 2017; ISBN 9781845936570.

361. Schmidtchen, A.; Pasupuleti, M.; Malmsten, M. Effect of hydrophobic modifications in antimicrobial peptides. Adv. Colloid Interface Sci. 2014, 205, 265-274. [CrossRef] [PubMed]

362. Ringstad, L.; Protopapa, E.; Lindholm-Sethson, B.; Schmidtchen, A.; Nelson, A.; Malmsten, M. An electrochemical study into the interaction between complement-derived peptides and DOPC mono- and bilayers. Langmuir 2008, 24, 208-216. [CrossRef] [PubMed]

363. Wang, G. Post-Translational Modifications of Natural Antimicrobial Peptides and Strategies for Peptide Engineering. Curr. Biotechnol. 2011, 1, 72-79. [CrossRef]

364. Taylor, S.W.; Craig, A.G.; Fischer, W.H.; Park, M.; Lehrer, R.I. Styelin D, an extensively modified antimicrobial peptide from ascidian hemocytes. J. Biol. Chem. 2000, 275, 38417-38426. [CrossRef] [PubMed]

365. Unger, T.; Oren, Z.; Shai, Y. The effect of cyclization of magainin 2 and melittin analogues on structure, function, and model membrane interactions: Implication to their mode of action. Biochemistry 2001, 40, 6388-6397. [CrossRef]

366. Koziel, J.; Bryzek, D.; Sroka, A.; Maresz, K.; Glowczyk, I.; Bielecka, E.; Kantyka, T.; Pyrć, K.; Svoboda, P.; Pohl, J.; et al. Citrullination Alters Immunomodulatory Function of LL-37 Essential for Prevention of Endotoxin-Induced Sepsis. J. Immunol. 2014, 192, 5363-5372. [CrossRef]

367. Picchianti, M.; Russo, C.; Castagnini, M.; Biagini, M.; Soldaini, E.; Balducci, E. NAD-dependent ADP-ribosylation of the human antimicrobial and immune-modulatory peptide LL-37 by ADP-ribosyltransferase-1. Innate Immun. 2015, 21, 314-321. [CrossRef] [PubMed]

368. Koro, C.; Hellvard, A.; Delaleu, N.; Binder, V.; Scavenius, C.; Bergum, B.; Gówczyk, I.; Roberts, H.M.; Chapple, I.L.C.; Grant, M.M.; et al. Carbamylated LL-37 as a modulator of the immune response. Innate Immun. 2016, 22, 218-229. [CrossRef] [PubMed]

369. Wang, G. Improved methods for classification, Prediction, And design of antimicrobial peptides. Methods Mol. Biol. 2015, 1268, 43-66. [CrossRef] [PubMed]

370. Nar, H.; Schmid, A.; Puder, C.; Potterat, O. High-resolution crystal structure of a lasso peptide. ChemMedChem 2010, 5, 1689-1692. [CrossRef] [PubMed]

371. Rosengren, K.J.; Clark, R.J.; Daly, N.L.; Göransson, U.; Jones, A.; Craik, D.J. Microcin J25 has a threaded sidechain-to-backbone ring structure and not a head-to-tail cyclized backbone. J. Am. Chem. Soc. 2003, 125, 12464-12474. [CrossRef] [PubMed]

372. Huang, Y.; Huang, J.; Chen, Y. Alpha-helical cationic antimicrobial peptides: Relationships of structure and function. Protein Cell 2010, 1, 143-152. [CrossRef] [PubMed]

373. Yi, H.Y.; Chowdhury, M.; Huang, Y.D.; Yu, X.Q. Insect antimicrobial peptides and their applications. Appl. Microbiol. Biotechnol. 2014, 98, 5807-5822. [CrossRef] [PubMed]

374. Lei, J.; Sun, L.C.; Huang, S.; Zhu, C.; Li, P.; He, J.; Mackey, V.; Coy, D.H.; He, Q.Y. The antimicrobial peptides and their potential clinical applications. Am. J. Transl. Res. 2019, 11, 3919-3931. [PubMed]

375. Hollmann, A.; Martinez, M.; Maturana, P.; Semorile, L.C.; Maffia, P.C. Antimicrobial peptides: Interaction with model and biological membranes and synergism with chemical antibiotics. Front. Chem. 2018, 6, 204. [CrossRef] [PubMed]

376. Uggerhøj, L.E.; Poulsen, T.J.; Munk, J.K.; Fredborg, M.; Sondergaard, T.E.; Frimodt-Moller, N.; Hansen, P.R.; Wimmer, R. Rational design of alpha-helical antimicrobial peptides: Do's and don'ts. ChemBioChem 2015, 16, 242-253. [CrossRef] [PubMed]

377. Oren, Z.; Shai, Y. Mode of action of linear amphipathic $\alpha$-helical antimicrobial peptides. Biopolymers 1998, 47, 451-463. [CrossRef]

378. Mohanram, H.; Bhattacharjya, S. Cysteine deleted protegrin-1 (CDP-1): Anti-bacterial activity, outer-membrane disruption and selectivity. Biochim. Biophys. Acta Gen. Subj. 2014, 1840, 3006-3016. [CrossRef] [PubMed]

379. Dhople, V.; Krukemeyer, A.; Ramamoorthy, A. The human beta-defensin-3, an antibacterial peptide with multiple biological functions. Biochim. Biophys. Acta Biomembr. 2006, 1758, 1499-1512. [CrossRef] [PubMed]

380. Rodziewicz-Motowidło, S.; Mickiewicz, B.; Greber, K.; Sikorska, E.; Szultka, Ł.; Kamysz, E.; Kamysz, W. Antimicrobial and conformational studies of the active and inactive analogues of the protegrin-1 peptide. FEBS J. 2010, 277, 1010-1022. [CrossRef] [PubMed]

381. Mandard, N.; Sodano, P.; Labbe, H.; Bonmatin, J.M.; Bulet, P.; Hetru, C.; Ptak, M.; Vovelle, F. Solution structure of thanatin, a potent bactericidal and fungicidal insect peptide, determined from proton two-dimensional nuclear magnetic resonance data. Eur. J. Biochem. 1998, 256, 404-410. [CrossRef] [PubMed] 
382. Laederach, A.; Andreotti, A.H.; Fulton, D.B. Solution and micelle-bound structures of tachyplesin I and its active aromatic linear derivatives. Biochemistry 2002, 41, 12359-12368. [CrossRef] [PubMed]

383. Powers, J.P.S.; Rozek, A.; Hancock, R.E.W. Structure-activity relationships for the $\beta$-hairpin cationic antimicrobial peptide polyphemusin I. Biochim. Biophys. Acta Proteins Proteomics 2004, 1698, 239-250. [CrossRef] [PubMed]

384. Mandard, N.; Bulet, P.; Caille, A.; Daffre, S.; Vovelle, F. The solution structure of gomesin, an antimicrobial cysteine-rich peptide from the spider. Eur. J. Biochem. 2002, 269, 1190-1198. [CrossRef] [PubMed]

385. Thevissen, K.; Osborn, R.W.; Acland, D.P.; Broekaert, W.F. Specific, high affinity binding sites for an antifungal plant defensin on Neurospora crassa hyphae and microsomal membranes. J. Biol. Chem. 1997, 272, 32176-32181. [CrossRef]

386. Vriens, K.; Cammue, B.P.A.; Thevissen, K. Antifungal plant defensins: Mechanisms of action and production. Molecules 2014, 19, 12280-12303. [CrossRef] [PubMed]

387. de Medeiros, L.N.; Angeli, R.; Sarzedas, C.G.; Barreto-Bergter, E.; Valente, A.P.; Kurtenbach, E.; Almeida, F.C.L. Backbone dynamics of the antifungal Psd1 pea defensin and its correlation with membrane interaction by NMR spectroscopy. Biochim. Biophys. Acta Biomembr. 2010, 1798, 105-113. [CrossRef] [PubMed]

388. Lobo, D.S.; Pereira, I.B.; Fragel-Madeira, L.; Medeiros, L.N.; Cabral, L.M.; Faria, J.; Bellio, M.; Campos, R.C.; Linden, R.; Kurtenbach, E. Antifungal Pisum sativum defensin 1 interacts with Neurospora crassa cyclin F related to the cell cycle. Biochemistry 2007, 46, 987-996. [CrossRef] [PubMed]

389. Aerts, A.M.; François, I.E.J.A.; Meert, E.M.K.; Li, Q.T.; Cammue, B.P.A.; Thevissen, K. The antifungal activity of RsAFP2, a plant defensin from Raphanus sativus, involves the induction of reactive oxygen species in Candida albicans. J. Mol. Microbiol. Biotechnol. 2007, 13, 243-247. [CrossRef]

390. Hayes, B.M.E.; Bleackley, M.R.; Wiltshire, J.L.; Anderson, M.A.; Traven, A.; Van Der Weerden, N.L. Identification and mechanism of action of the plant defensin nad1 as a new member of the antifungal drug arsenal against candida albicans. Antimicrob. Agents Chemother. 2013, 57, 3667-3675. [CrossRef] [PubMed]

391. Van Der Weerden, N.L.; Lay, F.T.; Anderson, M.A. The plant defensin, NaD1, enters the cytoplasm of Fusarium oxysporum hyphae. J. Biol. Chem. 2008, 283, 14445-14452. [CrossRef]

392. Wang, G. Structural insight into the mechanisms of action of antimicrobial peptides and structure-based design. In Antimicrobial Peptides: Discovery, Design and Novel Therapeutic Strategies; Cabi: Wallingford, UK, 2017; pp. 169-187.

393. Rozek, A.; Friedrich, C.L.; Hancock, R.E.W. Structure of the bovine antimicrobial peptide indolicidin bound to dodecylphosphocholine and sodium dodecyl sulfate micelles. Biochemistry 2000, 39, 15765-15774. [CrossRef] [PubMed]

394. Schibli, D.J.; Hwang, P.M.; Vogel, H.J. Structure of the antimicrobial peptide tritrpticin bound to micelles: A distinct membranebound peptide fold. Biochemistry 1999, 38, 16749-16755. [CrossRef] [PubMed]

395. Nguyen, L.T.; Schibli, D.J.; Vogel, H.J. Structural studies and model membrane interactions of two peptides derived from bovine lactoferricin. J. Pept. Sci. 2005, 11, 379-389. [CrossRef] [PubMed]

396. Li, W.; Tailhades, J.; O’Brien-Simpson, N.M.; Separovic, F.; Otvos, L.; Hossain, M.A.; Wade, J.D. Proline-rich antimicrobial peptides: Potential therapeutics against antibiotic-resistant bacteria. Amino Acids 2014, 46, 2287-2294. [CrossRef] [PubMed]

397. Krizsan, A.; Volke, D.; Weinert, S.; Sträter, N.; Knappe, D.; Hoffmann, R. Insect-Derived Proline-Rich Antimicrobial Peptides Kill Bacteria by Inhibiting Bacterial Protein Translation at the 70 S Ribosome. Angew. Chemie Int. Ed. 2014, 53, 12236-12239. [CrossRef] [PubMed]

398. Mardirossian, M.; Grzela, R.; Giglione, C.; Meinnel, T.; Gennaro, R.; Mergaert, P.; Scocchi, M. The host antimicrobial peptide Bac71-35 binds to bacterial ribosomal proteins and inhibits protein synthesis. Chem. Biol. 2014, 21, 1639-1647. [CrossRef] [PubMed]

399. Seefeldt, A.C.; Nguyen, F.; Antunes, S.; Pérébaskine, N.; Graf, M.; Arenz, S.; Inampudi, K.K.; Douat, C.; Guichard, G.; Wilson, D.N.; et al. The proline-rich antimicrobial peptide Onc112 inhibits translation by blocking and destabilizing the initiation complex. Nat. Struct. Mol. Biol. 2015, 22, 470-475. [CrossRef] [PubMed]

400. Lee, J.T.Y.; Wang, G.; Tam, Y.T.; Tam, C. Membrane-active epithelial keratin 6A fragments (KAMPs) are unique human antimicrobial peptides with a non- $\alpha \beta$ structure. Front. Microbiol. 2016, 7, 1799. [CrossRef]

401. Koehbach, J.; Craik, D.J. The Vast Structural Diversity of Antimicrobial Peptides. Trends Pharmacol. Sci. 2019, 40, 517-528. [CrossRef] [PubMed]

402. Gabrielsen, C.; Brede, D.A.; Nes, I.F.; Diep, D.B. Circular bacteriocins: Biosynthesis and mode of action. Appl. Environ. Microbiol. 2014, 80, 6854-6862. [CrossRef] [PubMed]

403. Martin-Visscher, L.A.; Gong, X.; Duszyk, M.; Vederas, J.C. The three-dimensional structure of carnocyclin A reveals that many circular bacteriocins share a common structural motif. J. Biol. Chem. 2009, 284, 28674-28681. [CrossRef] [PubMed]

404. Himeno, K.; Rosengren, K.J.; Inoue, T.; Perez, R.H.; Colgrave, M.L.; Lee, H.S.; Chan, L.Y.; Henriques, S.T.; Fujita, K.; Ishibashi, N.; et al. Identification, Characterization, and Three-Dimensional Structure of the Novel Circular Bacteriocin, Enterocin NKR-5-3B, from Enterococcus faecium. Biochemistry 2015, 54, 4863-4876. [CrossRef] [PubMed]

405. Craik, D.J.; Clark, R.J.; Daly, N.L. Potential therapeutic applications of the cyclotides and related cystine knot mini-proteins. Expert Opin. Investig. Drugs 2007, 16, 595-604. [CrossRef] [PubMed]

406. Tam, J.P.; Lu, Y.A.; Yang, J.L.; Chiu, K.W. An unusual structural motif of antimicrobial peptides containing end-to-end macrocycle and cystine-knot disulfides. Proc. Natl. Acad. Sci. USA 1999, 96, 8913-8918. [CrossRef] [PubMed] 
407. Daly, N.L.; Gustafson, K.R.; Craik, D.J. The role of the cyclic peptide backbone in the anti-HIV activity of the cyclotide kalata B1. FEBS Lett. 2004, 574, 69-72. [CrossRef] [PubMed]

408. Craik, D.J.; Daly, N.L.; Waine, C. The cystine knot motif in toxins and implications for drug design. Toxicon 2001, 39, 43-60. [CrossRef]

409. Daly, N.L.; Koltay, A.; Gustafson, K.R.; Boyd, M.R.; Casas-Finet, J.R.; Craik, D.J. Solution structure by NMR of circulin A: A macrocyclic knotted peptide having anti-HIV activity. J. Mol. Biol. 1999, 285, 333-345. [CrossRef] [PubMed]

410. Koltay, A.; Daly, N.L.; Gustafson, K.R.; Craik, D.J. Structure of circulin B and implications for antimicrobial activity of the cyclotides. Int. J. Pept. Res. Ther. 2005, 11, 99-106. [CrossRef]

411. Gustafson, K.R.; Sowder, R.C.; Henderson, L.E.; Parsons, I.C.; Kashman, Y.; Cardellina, J.H.; McMahon, J.B.; Buckheit Jr, R.W.; Pannell, L.K.; Boyd, M.R. Circulins A and B. Novel human immunodeficiency virus (HIV)-inhibitory macrocyclic peptides from the tropical tree Chassalia parvifolia. J. Am. Chem. Soc. 1994, 116, 9337-9338. [CrossRef]

412. Fujitani, N.; Kouno, T.; Nakahara, T.; Takaya, K.; Osaki, T.; Kawabata, S.I.; Mizuguchi, M.; Aizawa, T.; Demura, M.; Nishimura, S.I.; et al. The solution structure of horseshoe crab antimicrobial peptide tachystatin B with an inhibitory cystine-knot motif. $J$. Pept. Sci. 2007, 13, 269-279. [CrossRef] [PubMed]

413. Kawulka, K.E.; Sprules, T.; Diaper, C.M.; Whittal, R.M.; McKay, R.T.; Mercier, P.; Zuber, P.; Vederas, J.C. Structure of Subtilosin A, A Cyclic Antimicrobial Peptide from Bacillus subtilis with Unusual Sulfur to $\alpha$-Carbon Cross-Links: Formation and Reduction of $\alpha$-Thio- $\alpha$-Amino Acid Derivatives. Biochemistry 2004, 43, 3385-3395. [CrossRef] [PubMed]

414. Trabi, M.; Schirra, H.J.; Craik, D.J. Three-dimensional structure of RTD-1, a cyclic antimicrobial defensin from rhesus macaque leukocytes. Biochemistry 2001, 40, 4211-4221. [CrossRef] [PubMed]

415. Bastian, A.; Schäfer, H. Human $\alpha$-defensin 1 (HNP-1) inhibits adenoviral infection in vitro. Regul. Pept. 2001, 101, 157-161. [CrossRef]

416. Edward Robinson, W.; McDougall, B.; Tran, D.; Selsted, M.E. Anti-HIV-1 activity of indolicidin, an antimicrobial peptide from neutrophils. J. Leukoc. Biol. 1998, 63, 94-100. [CrossRef] [PubMed]

417. Tamamura, H.; Ishihara, T.; Otaka, A.; Murakami, T.; Ibuka, T.; Waki, M.; Matsumoto, A.; Yamamoto, N.; Fujii, N. Analysis of the interaction of an anti-HIV peptide, T22 ([Tyr5,12, Lys7]-polyphemusin II), with gp120 and CD4 by surface plasmon resonance. Biochim. Biophys. Acta Protein Struct. Mol. Enzymol. 1996, 1298, 37-44. [CrossRef]

418. Belaid, A.; Aouni, M.; Khelifa, R.; Trabelsi, A.; Jemmali, M.; Hani, K. In vitro antiviral activity of dermaseptins against herpes simplex virus type 1. J. Med. Virol. 2002, 66, 229-234. [CrossRef] [PubMed]

419. Hasegawa, K.; Motsuchi, W.; Tanaka, S.; Dosakol, S.I. Inhibition with lactoferrin of in vitro infection with human herpes VIRUS Japanese J. Med. Sci. Biol. 1994, 47, 73-85. [CrossRef] [PubMed]

420. Marchetti, M.; Longhi, C.; Conte, M.P.; Pisani, S.; Valenti, P.; Seganti, L. Lactoferrin inhibits herpes simplex virus type 1 adsorption to Vero cells. Antiviral Res. 1996, 29, 221-231. [CrossRef]

421. Andersen, J.H.; Jenssen, H.; Sandvik, K.; Gutteberg, T.J. Anti-HSV activity of lactoferrin and lactoferricin is dependent on the presence of heparan sulphate at the cell surface. J. Med. Virol. 2004, 74, 262-271. [CrossRef] [PubMed]

422. Sinha, S.; Cheshenko, N.; Lehrer, R.I.; Herold, B.C. NP-1, a rabbit $\alpha$-defensin, prevents the entry and intercellular spread of herpes simplex virus type 2. Antimicrob. Agents Chemother. 2003, 47, 494-500. [CrossRef] [PubMed]

423. Liu, Y.; Gong, W.; Huang, C.C.; Herr, W.; Cheng, X. Crystal structure of the conserved core of the herpes simplex virus transcriptional regulatory protein VP16. Genes Dev. 1999, 13, 1692-1703. [CrossRef] [PubMed]

424. Wachinger, M.; Kleinschmidt, A.; Winder, D.; Von Pechmann, N.; Ludvigsen, A.; Neumann, M.; Holle, R.; Salmons, B.; Erfle, V.; Brack-Werner, R. Antimicrobial peptides melittin and cecropin inhibit replication of human immunodeficiency virus 1 by suppressing viral gene expression. J. Gen. Virol. 1998, 79, 731-740. [CrossRef] [PubMed]

425. Albiol Matanic, V.C.; Castilla, V. Antiviral activity of antimicrobial cationic peptides against Junin virus and herpes simplex virus. Int. J. Antimicrob. Agents 2004, 23, 382-389. [CrossRef] [PubMed]

426. Hayashiya, K. Red Fluorescent Protein in the Digestive Juice of the Silkworm Larvae Fed on Host-Plant Mulberry Leaves. Entomol. Exp. Appl. 1978, 24, 428-436. [CrossRef]

427. Funakoshi, M.; Aizawa, K. Antiviral substance in the silkworm gut juice against a nuclear polyhedrosis virus of the silkworm, Bombyx mori. J. Invertebr. Pathol. 1989, 53, 135-136. [CrossRef]

428. Sunagar, S.G.; Savanurmath, C.J.; Hinchigeri, S.B. The profiles of red fluorescent proteins with antinucleopolyhedrovirus activity in races of the silkworm Bombyx mori. J. Insect Physiol. 2011, 57, 1707-1714. [CrossRef] [PubMed]

429. Hiraki, A.; Hirayama, E.; Kim, J. Antiviral substance from silkworm faeces: Characterization of its antiviral activity. Microbiol. Immunol. 2000, 44, 669-676. [CrossRef] [PubMed]

430. Zhang, L.; Rozek, A.; Hancock, R.E.W. Interaction of Cationic Antimicrobial Peptides with Model Membranes. J. Biol. Chem. 2001, 276, 35714-35722. [CrossRef] [PubMed]

431. Shai, Y. Mode of action of membrane active antimicrobial peptides. Biopolym. Pept. Sci. Sect. 2002, 66, 236-248. [CrossRef] [PubMed]

432. Lai, R.; Liu, H.; Hui Lee, W.; Zhang, Y. An anionic antimicrobial peptide from toad Bombina maxima. Biochem. Biophys. Res. Commun. 2002, 295, 796-799. [CrossRef]

433. Brogden, K.A.; Ackermann, M.; Huttner, K.M. Small, anionic, and charge-neutralizing propeptide fragments of zymogens are antimicrobial. Antimicrob. Agents Chemother. 1997, 41, 1615-1617. [CrossRef] [PubMed] 
434. Gales, A.C.; Jones, R.N.; Sader, H.S. Contemporary activity of colistin and polymyxin B against a worldwide collection of Gram-negative pathogens: Results from the SENTRY antimicrobial surveillance program (2006-09). J. Antimicrob. Chemother. 2011, 66, 2070-2074. [CrossRef]

435. Huang, H.W. DAPTOMYCIN, its membrane-active mechanism vs. that of other antimicrobial peptides. Biochim. Biophys. Acta Biomembr. 2020, 1862. [CrossRef]

436. Kahne, D.; Leimkuhler, C.; Lu, W.; Walsh, C. Glycopeptide and lipoglycopeptide antibiotics. Chem. Rev. 2005, 105, 425-448. [CrossRef] [PubMed]

437. Reynolds, P.E. Structure, biochemistry and mechanism of action of glycopeptide antibiotics. Eur. J. Clin. Microbiol. Infect. Dis. 1989, 8, 943-950. [CrossRef]

438. Cooper, M.A.; Williams, D.H. Binding of glycopeptide antibiotics to a model of a vancomycin-resistant bacterium. Chem. Biol. 1999, 6, 891-899. [CrossRef]

439. Bahar, A.A.; Ren, D. Antimicrobial peptides. Pharmaceuticals 2013, 6, 1543-1575. [CrossRef]

440. Cruciani, R.A.; Barker, J.L.; Durell, S.R.; Raghunathan, G.; Robert Guy, H.; Zasloff, M.; Stanley, E.F. Magainin 2, a natural antibiotic from frog skin, forms ion channels in lipid bilayer membranes. Eur. J. Pharmacol. Mol. Pharmacol. 1992, 226, 287-296. [CrossRef]

441. Shai, Y.; Oren, Z. From "carpet" mechanism to de-novo designed diastereomeric cell-selective antimicrobial peptides. Peptides 2001, 22, 1629-1641. [CrossRef]

442. Sengupta, D.; Leontiadou, H.; Mark, A.E.; Marrink, S.J. Toroidal pores formed by antimicrobial peptides show significant disorder. Biochim. Biophys. Acta Biomembr. 2008, 1778, 2308-2317. [CrossRef] [PubMed]

443. Wadhwani, P.; Epand, R.F.; Heidenreich, N.; Bürck, J.; Ulrich, A.S.; Epand, R.M. Membrane-active peptides and the clustering of anionic lipids. Biophys. J. 2012, 103, 265-274. [CrossRef] [PubMed]

444. Brogden, K.A. Antimicrobial peptides: Pore formers or metabolic inhibitors in bacteria? Nat. Rev. Microbiol. 2005, 3, 238-250. [CrossRef] [PubMed]

445. Lohner, K.; Prossnigg, F. Biological activity and structural aspects of PGLa interaction with membrane mimetic systems. Biochim. Biophys. Acta Biomembr. 2009. [CrossRef] [PubMed]

446. Rapaport, D.; Shai, Y. Interaction of fluorescently labeled pardaxin and its analogues with lipid bilayers. J. Biol. Chem. 1991, 266, 23769-23775. [CrossRef]

447. Yang, L.; Harroun, T.A.; Weiss, T.M.; Ding, L.; Huang, H.W. Barrel-stave model or toroidal model? A case study on melittin pores. Biophys. J. 2001, 81, 1475-1485. [CrossRef]

448. Shai, Y. Mechanism of the binding, insertion and destabilization of phospholipid bilayer membranes by $\alpha$-helical antimicrobial and cell non-selective membrane-lytic peptides. Biochim. Biophys. Acta Biomembr. 1999, 1462, 55-70. [CrossRef]

449. Gazit, E.; Shai, Y. Structural and Functional Characterization of the $\alpha 5$ Segment of Bacillus thuringiensis $\delta$-Endotoxin. Biochemistry 1993, 32, 3429-3436. [CrossRef] [PubMed]

450. Shenkarev, Z.O.; Paramonov, A.S.; Lyukmanova, E.N.; Gizatullina, A.K.; Zhuravleva, A.V.; Tagaev, A.A.; Yakimenko, Z.A.; Telezhinskaya, I.N.; Kirpichnikov, M.P.; Ovchinnikova, T.V.; et al. Peptaibol antiamoebin I: Spatial structure, backbone dynamics, interaction with bicelles and lipid-protein nanodiscs, and pore formation in context of barrel-stave model. Chem. Biodivers. 2013, 10, 838-863. [CrossRef] [PubMed]

451. Moll, G.N.; Konings, W.N.; Driessen, A.J.M. Bacteriocins: Mechanism of membrane insertion and pore formation. Antonie van Leeuwenhoek, Int. J. Gen. Mol. Microbiol. 1999, 76, 185-198. [CrossRef]

452. Hara, T.; Mitani, Y.; Tanaka, K.; Uematsu, N.; Takakura, A.; Tachi, T.; Kodama, H.; Kondo, M.; Mori, H.; Otaka, A.; et al. Heterodimer formation between the antimicrobial peptides magainin 2 and PGLa in lipid bilayers: A cross-linking study. Biochemistry 2001, 40, 12395-12399. [CrossRef] [PubMed]

453. Campagna, S.; Saint, N.; Molle, G.; Aumelas, A. Structure and mechanism of action of the antimicrobial peptide piscidin. Biochemistry 2007, 46, 1771-1778. [CrossRef] [PubMed]

454. Hara, T.; Kodama, H.; Kondo, M.; Wakamatsu, K.; Takeda, A.; Tachi, T.; Matsuzaki, K. Effects of peptide dimerization on pore formation: Antiparallel disulfide-dimerized magainin 2 analogue. Biopolymers 2001, 58, 437-446. [CrossRef]

455. Shenkarev, Z.O.; Balandin, S.V.; Trunov, K.I.; Paramonov, A.S.; Sukhanov, S.V.; Barsukov, L.I.; Arseniev, A.S.; Ovchinnikova, T.V. Molecular mechanism of action of $\beta$-Hairpin antimicrobial peptide arenicin: Oligomeric structure in dodecylphosphocholine micelles and pore formation in planar lipid bilayers. Biochemistry 2011, 50, 6255-6265. [CrossRef]

456. Leontiadou, H.; Mark, A.E.; Marrink, S.J. Antimicrobial peptides in action. J. Am. Chem. Soc. 2006, 128, 12156-12161. [CrossRef] [PubMed]

457. Yoneyama, F.; Imura, Y.; Ohno, K.; Zendo, T.; Nakayama, J.; Matsuzaki, K.; Sonomoto, K. Peptide-lipid huge toroidal pore, a new antimicrobial mechanism mediated by a lactococcal bacteriocin, lacticin Q. Antimicrob. Agents Chemother. 2009, 53, $3211-3217$. [CrossRef] [PubMed]

458. Allende, D.; Simon, S.A.; McIntosh, T.J. Melittin-induced bilayer leakage depends on lipid material properties: Evidence for toroidal pores. Biophys. J. 2005, 88, 1828-1837. [CrossRef] [PubMed]

459. Ladokhin, A.S.; White, S.H. "Detergent-like" permeabilization of anionic lipid vesicles by melittin. Biochim. Biophys. Acta Biomembr. 2001, 1514, 253-260. [CrossRef]

460. Saint, N.; Cadiou, H.; Bessin, Y.; Molle, G. Antibacterial peptide pleurocidin forms ion channels in planar lipid bilayers. Biochim. Biophys. Acta Biomembr. 2002, 1564, 359-364. [CrossRef] 
461. Bond, P.J.; Parton, D.L.; Clark, J.F.; Sansom, M.S.P. Coarse-grained simulations of the membrane-active antimicrobial peptide maculatin 1.1. Biophys. J. 2008, 95, 3802-3815. [CrossRef]

462. Sharma, S.; Sahoo, N.; Bhunia, A. Antimicrobial Peptides and their Pore/Ion Channel Properties in Neutralization of Pathogenic Microbes. Curr. Top. Med. Chem. 2015, 16, 46-53. [CrossRef] [PubMed]

463. Sitaram, N.; Nagaraj, R. Interaction of antimicrobial peptides with biological and model membranes: Structural and charge requirements for activity. Biochim. Biophys. Acta Biomembr. 1999, 1462, 29-54. [CrossRef]

464. Marchand, C.; Krajewski, K.; Lee, H.F.; Antony, S.; Johnson, A.A.; Amin, R.; Roller, P.; Kvaratskhelia, M.; Pommier, Y. Covalent binding of the natural antimicrobial peptide indolicidin to DNA abasic sites. Nucleic Acids Res. 2006, 34, 5157-5165. [CrossRef] [PubMed]

465. Subbalakshmi, C.; Sitaram, N. Mechanism of antimicrobial action of indolicidin. FEMS Microbiol. Lett. 1998, 160, 91-96. [CrossRef] [PubMed]

466. Fernandez, D.I.; Le Brun, A.P.; Whitwell, T.C.; Sani, M.A.; James, M.; Separovic, F. The antimicrobial peptide aurein 1.2 disrupts model membranes via the carpet mechanism. Phys. Chem. Chem. Phys. 2012, 14, 15739-15751. [CrossRef] [PubMed]

467. Wong, H.; Bowie, J.H.; Carver, J.A. The solution structure and activity of caerin 1.1, an antimicrobial peptide from the Australian green tree frog, Litoria splendida. Eur. J. Biochem. 1997, 247, 545-557. [CrossRef]

468. Monaco, V.; Formaggio, F.; Crisma, M.; Toniolo, C.; Hanson, P.; Millhauser, G.L. Orientation and immersion depth of a helical lipopeptaibol in membranes using TOAC as an ESR probe. Biopolymers 1999, 50, 239-253. [CrossRef]

469. Otvos, L. Antibacterial peptides and proteins with multiple cellular targets. J. Pept. Sci. 2005, 11, 697-706. [CrossRef] [PubMed]

470. Chen, L.; Harrison, S.D. Cell-penetrating peptides in drug development: Enabling intracellular targets. Biochem. Soc. Trans. 2007, 35, 821-825. [CrossRef] [PubMed]

471. Park, C.B.; Kim, M.S.; Kim, S.C. A novel antimicrobial peptide from Bufo bufo gargarizans. Biochem. Biophys. Res. Commun. 1996, 218, 408-413. [CrossRef] [PubMed]

472. Park, C.B.; Kim, H.S.; Kim, S.C. Mechanism of action of the antimicrobial peptide buforin II: Buforin II kills microorganisms by penetrating the cell membrane and inhibiting cellular functions. Biochem. Biophys. Res. Commun. 1998, 244, 253-257. [CrossRef] [PubMed]

473. Park, C.B.; Yi, K.S.; Matsuzaki, K.; Kim, M.S.; Kim, S.C. Structure-activity analysis of buforin II, a histone H2A-derived antimicrobial peptide: The proline hinge is responsible for the cell-penetrating ability of buforin II. Proc. Natl. Acad. Sci. USA 2000, 97, 8245-8250. [CrossRef] [PubMed]

474. Bustillo, M.E.; Fischer, A.L.; Labouyer, M.A.; Klaips, J.A.; Webb, A.C.; Elmore, D.E. Modular analysis of hipposin, a histonederived antimicrobial peptide consisting of membrane translocating and membrane permeabilizing fragments. Biochim. Biophys. Acta Biomembr. 2014, 1838, 2228-2233. [CrossRef] [PubMed]

475. Birkemo, G.A.; Lüders, T.; Andersen, Ø.; Nes, I.F.; Nissen-Meyer, J. Hipposin, a histone-derived antimicrobial peptide in Atlantic halibut (Hippoglossus hippoglossus L.). Biochim. Biophys. Acta Proteins Proteomics 2003, 1646, 207-215. [CrossRef]

476. Schibli, D.J.; Epand, R.F.; Vogel, H.J.; Epand, R.M. Tryptophan-rich antimicrobial peptides: Comparative properties and membrane interactions. Biochem. Cell Biol. 2002, 80, 667-677. [CrossRef]

477. Sugiarto, H.; Yu, P.L. Mechanisms of action of ostrich $\beta$-defensins against Escherichia coli. FEMS Microbiol. Lett. 2007, 270, 195-200. [CrossRef] [PubMed]

478. Vizan, J.L.; Hernandez-Chico, C.; Del Castillo, I.; Moreno, F. The peptide antibiotic microcin B17 induces double-strand cleavage of DNA mediated by E. coli DNA gyrase. EMBO J. 1991, 10, 467-476. [CrossRef] [PubMed]

479. Boman, H.G.; Agerberth, B.; Boman, A. Mechanisms of action on Escherichia coli of cecropin P1 and PR-39, two antibacterial peptides from pig intestine. Infect. Immun. 1993, 61, 2978-2984. [CrossRef] [PubMed]

480. Lutkenhaus, J. Regulation of cell division in E. coli. Trends Genet. 1990, 6, 22-25. [CrossRef]

481. Delgado, M.A.; Rintoul, M.R.; Farías, R.N.; Salomón, R.A. Escherichia coli RNA polymerase is the target of the cyclopeptide antibiotic microcin J25. J. Bacteriol. 2001, 183, 4543-4550. [CrossRef] [PubMed]

482. Chileveru, H.R.; Lim, S.A.; Chairatana, P.; Wommack, A.J.; Chiang, I.L.; Nolan, E.M. Visualizing attack of escherichia coli by the antimicrobial peptide human defensin 5. Biochemistry 2015, 54, 1767-1777. [CrossRef] [PubMed]

483. Huan, Y.; Kong, Q.; Mou, H.; Yi, H. Antimicrobial Peptides: Classification, Design, Application and Research Progress in Multiple Fields. Front. Microbiol. 2020, 11. [CrossRef] [PubMed]

484. Patrzykat, A.; Friedrich, C.L.; Zhang, L.; Mendoza, V.; Hancock, R.E.W. Sublethal concentrations of pleurocidin-derived antimicrobial peptides inhibit macromolecular synthesis in Escherichia coli. Antimicrob. Agents Chemother. 2002, 46, 605-614. [CrossRef] [PubMed]

485. Le, C.F.; Gudimella, R.; Razali, R.; Manikam, R.; Sekaran, S.D. Transcriptome analysis of Streptococcus pneumoniae treated with the designed antimicrobial peptides, DM3. Sci. Rep. 2016, 6. [CrossRef] [PubMed]

486. Matsumoto, K.; Yamazaki, K.; Kawakami, S.; Miyoshi, D.; Ooi, T.; Hashimoto, S.; Taguchi, S. In vivo target exploration of apidaecin based on Acquired Resistance induced by Gene Overexpression (ARGO assay). Sci. Rep. 2017, 7. [CrossRef]

487. Ho, Y.H.; Shah, P.; Chen, Y.W.; Chen, C.S. Systematic analysis of intracellular-targeting antimicrobial peptides, bactenecin 7, hybrid of pleurocidin and dermaseptin, proline-arginine-rich peptide, and lactoferricin $b$, by using Escherichia coli proteome microarrays. Mol. Cell. Proteomics 2016, 15, 1837-1847. [CrossRef] [PubMed]

488. Jenssen, H.; Hamill, P.; Hancock, R.E.W. Peptide antimicrobial agents. Clin. Microbiol. Rev. 2006, 19, 491-511. [CrossRef] [PubMed] 
489. Otvos, L.; Insug, O.; Rogers, M.E.; Consolvo, P.J.; Condie, B.A.; Lovas, S.; Bulet, P.; Blaszczyk-Thurin, M. Interaction between heat shock proteins and antimicrobial peptides. Biochemistry 2000, 39, 14150-14159. [CrossRef] [PubMed]

490. Chesnokova, L.S.; Slepenkov, S.V.; Witt, S.N. The insect antimicrobial peptide, L-pyrrhocoricin, binds to and stimulates the ATPase activity of both wild-type and lidless DnaK. FEBS Lett. 2004, 565, 65-69. [CrossRef] [PubMed]

491. Kragol, G.; Lovas, S.; Varadi, G.; Condie, B.A.; Hoffmann, R.; Otvos, L. The antibacterial peptide pyrrhocoricin inhibits the ATPase actions of DnaK and prevents chaperone-assisted protein folding. Biochemistry 2001, 40, 3016-3026. [CrossRef] [PubMed]

492. Scocchi, M.; Lüthy, C.; Decarli, P.; Mignogna, G.; Christen, P.; Gennaro, R. The Proline-rich Antibacterial Peptide Bac7 Binds to and Inhibits in vitro the Molecular Chaperone DnaK. Int. J. Pept. Res. Ther. 2009, 15, 147-155. [CrossRef]

493. Knappe, D.; Zahn, M.; Sauer, U.; Schiffer, G.; Sträter, N.; Hoffmann, R. Rational Design of Oncocin Derivatives with Superior Protease Stabilities and Antibacterial Activities Based on the High-Resolution Structure of the Oncocin-DnaK Complex. ChemBioChem 2011, 12, 874-876. [CrossRef] [PubMed]

494. Knappe, D.; Piantavigna, S.; Hansen, A.; Mechler, A.; Binas, A.; Nolte, O.; Martin, L.L.; Hoffmann, R. Oncocin (VDKPPYLPRPRPPRRIYNR-NH2): A novel antibacterial peptide optimized against gram-negative human pathogens. J. Med. Chem. 2010, 53, 5240-5247. [CrossRef] [PubMed]

495. Couto, M.A.; Harwig, S.S.L.; Lehrer, R.I. Selective inhibition of microbial serine proteases by eNAP-2, an antimicrobial peptide from equine neutrophils. Infect. Immun. 1993, 61, 2991-2994. [CrossRef] [PubMed]

496. Fogaça, A.C.; Almeida, I.C.; Eberlin, M.N.; Tanaka, A.S.; Bulet, P.; Daffre, S. Ixodidin, a novel antimicrobial peptide from the hemocytes of the cattle tick Boophilus microplus with inhibitory activity against serine proteinases. Peptides 2006, 27, 667-674. [CrossRef] [PubMed]

497. Troxler, R.F.; Offner, G.D.; Xu, T.; Vanderspek, J.C.; Oppenheim, F.G. Structural Relationship Between Human Salivary Histatins. J. Dent. Res. 1990, 69, 2-6. [CrossRef] [PubMed]

498. Mackay, B.J.; Denepitiya, L.; Iacono, V.J.; Krost, S.B.; Pollock, J.J. Growth-inhibitory and bactericidal effects of human parotid salivary histidine-rich polypeptides on Streptococcus mutans. Infect. Immun. 1984, 44, 695-701. [CrossRef]

499. Nishikata, M.; Kanehira, T.; Oh, H.; Tani, H.; Tazaki, M.; Kuboki, Y. Salivary histatin as an inhibitor of a protease produced by the oral bacterium Bacteroides gingivalis. Biochem. Biophys. Res. Commun. 1991, 174, 625-630. [CrossRef]

500. Brötz, H.; Bierbaum, G.; Reynolds, P.E.; Sahl, H.G. The lantibiotic mersacidin inhibits peptidoglycan biosynthesis at the level of transglycosylation. Eur. J. Biochem. 1997, 246, 193-199. [CrossRef] [PubMed]

501. Arnison, P.G.; Bibb, M.J.; Bierbaum, G.; Bowers, A.A.; Bugni, T.S.; Bulaj, G.; Camarero, J.A.; Campopiano, D.J.; Challis, G.L.; Clardy, J.; et al. Ribosomally synthesized and post-translationally modified peptide natural products: Overview and recommendations for a universal nomenclature. Nat. Prod. Rep. 2013, 30, 108-160. [CrossRef] [PubMed]

502. Sass, V.; Schneider, T.; Wilmes, M.; Körner, C.; Tossi, A.; Novikova, N.; Shamova, O.; Sahl, H.G. Human $\beta$-defensin 3 inhibits cell wall biosynthesis in staphylococci. Infect. Immun. 2010, 78, 2793-2800. [CrossRef] [PubMed]

503. de Leeuw, E.; Li, C.; Zeng, P.; Li, C.; de Buin, M.D.; Lu, W.Y.; Breukink, E.; Lu, W. Functional interaction of human neutrophil peptide-1 with the cell wall precursor lipid II. FEBS Lett. 2010, 584, 1543-1548. [CrossRef]

504. Song, C.; Weichbrodt, C.; Salnikov, E.S.; Dynowski, M.; Forsberg, B.O.; Bechinger, B.; Steinem, C.; De Groot, B.L.; Zachariae, U.; Zeth, K. Crystal structure and functional mechanism of a human antimicrobial membrane channel. Proc. Natl. Acad. Sci. USA 2013, 110, 4586-4591. [CrossRef]

505. Perrin, B.S.; Tian, Y.; Fu, R.; Grant, C.V.; Chekmenev, E.Y.; Wieczorek, W.E.; Dao, A.E.; Hayden, R.M.; Burzynski, C.M.; Venable, R.M.; et al. High-resolution structures and orientations of antimicrobial peptides piscidin 1 and piscidin 3 in fluid bilayers reveal tilting, kinking, and bilayer immersion. J. Am. Chem. Soc. 2014, 136, 3491-3504. [CrossRef] [PubMed]

506. Henzler Wildman, K.A.; Lee, D.K.; Ramamoorthy, A. Mechanism of lipid bilayer disruption by the human antimicrobial peptide, LL-37. Biochemistry 2003, 42, 6545-6558. [CrossRef] [PubMed]

507. Fernández de Ullivarri, M.; Arbulu, S.; Garcia-Gutierrez, E.; Cotter, P.D. Antifungal Peptides as Therapeutic Agents. Front. Cell. Infect. Microbiol. 2020, 10. [CrossRef] [PubMed]

508. Bowman, S.M.; Free, S.J. The structure and synthesis of the fungal cell wall. BioEssays 2006, 28, 799-808. [CrossRef] [PubMed]

509. Gray, K.C.; Palacios, D.S.; Dailey, I.; Endo, M.M.; Uno, B.E.; Wilcock, B.C.; Burke, M.D. Amphotericin primarily kills yeast by simply binding ergosterol. Proc. Natl. Acad. Sci. USA 2012, 109, 2234-2239. [CrossRef] [PubMed]

510. Yamamoto, T.; Umegawa, Y.; Yamagami, M.; Suzuki, T.; Tsuchikawa, H.; Hanashima, S.; Matsumori, N.; Murata, M. The Perpendicular Orientation of Amphotericin B Methyl Ester in Hydrated Lipid Bilayers Supports the Barrel-Stave Model. Biochemistry 2019, 58, 2282-2291. [CrossRef] [PubMed]

511. Galanth, C.; Abbassi, F.; Lequin, O.; Ayala-Sanmartin, J.; Ladram, A.; Nicolas, P.; Amiche, M. Mechanism of antibacterial action of dermaseptin B2: Interplay between helix-Hinge-Helix structure and membrane curvature strain. Biochemistry 2009, 48, 313-327. [CrossRef] [PubMed]

512. Li, M.; Xi, X.; Ma, C.; Chen, X.; Zhou, M.; Burrows, J.F.; Chen, T.; Wang, L. A novel dermaseptin isolated from the skin secretion of phyllomedusa tarsius and its cationicity- enhanced analogue exhibiting effective antimicrobial and anti-proliferative activities. Biomolecules 2019, 9, 628. [CrossRef] [PubMed]

513. Benincasa, M.; Scocchi, M.; Pacor, S.; Tossi, A.; Nobili, D.; Basaglia, G.; Busetti, M.; Gennaro, R. Fungicidal activity of five cathelicidin peptides against clinically isolated yeasts. J. Antimicrob. Chemother. 2006, 58, 950-959. [CrossRef] [PubMed] 
514. De Cesare, G.B.; Cristy, S.A.; Garsin, D.A.; Lorenz, M.C. Antimicrobial peptides: A new frontier in antifungal therapy. Mbio 2020, 11, 1-21. [CrossRef]

515. Rose, P.W.; Prlić, A.; Bi, C.; Bluhm, W.F.; Christie, C.H.; Dutta, S.; Green, R.K.; Goodsell, D.S.; Westbrook, J.D.; Woo, J.; et al. The RCSB Protein Data Bank: Views of structural biology for basic and applied research and education. Nucleic Acids Res. 2015, 43, D345-D356. [CrossRef] [PubMed]

516. Jhong, J.H.; Chi, Y.H.; Li, W.C.; Lin, T.H.; Huang, K.Y.; Lee, T.Y. DbAMP: An integrated resource for exploring antimicrobial peptides with functional activities and physicochemical properties on transcriptome and proteome data. Nucleic Acids Res. 2019, 47, D285-D297. [CrossRef] [PubMed]

517. Pirtskhalava, M.; Gabrielian, A.; Cruz, P.; Griggs, H.L.; Squires, R.B.; Hurt, D.E.; Grigolava, M.; Chubinidze, M.; Gogoladze, G.; Vishnepolsky, B.; et al. DBAASP v.2: An enhanced database of structure and antimicrobial/cytotoxic activity of natural and synthetic peptides. Nucleic Acids Res. 2016, 44, D1104-D1112. [CrossRef] [PubMed]

518. Moon, C.P.; Fleming, K.G. Side-chain hydrophobicity scale derived from transmembrane protein folding into lipid bilayers. Proc. Natl. Acad. Sci. USA 2011, 108, 10174-10177. [CrossRef] [PubMed]

519. Wimley, W.C.; White, S.H. Experimentally determined hydrophobicity scale for proteins at membrane interfaces. Nat. Struct. Biol. 1996, 3, 842-848. [CrossRef] [PubMed]

520. Eisenberg, D.; Weiss, R.M.; Terwilliger, T.C. The hydrophobic moment detects periodicity in protein hydrophobicity. Proc. Natl. Acad. Sci. USA 1984, 81, 140-144. [CrossRef]

521. Koehler, J.; Woetzel, N.; Staritzbichler, R.; Sanders, C.R.; Meiler, J. A unified hydrophobicity scale for multispan membrane proteins. Proteins Struct. Funct. Bioinforma. 2009, 76, 13-29. [CrossRef] [PubMed]

522. Hessa, T.; Kim, H.; Bihlmaier, K.; Lundin, C.; Boekel, J.; Andersson, H.; Nilsson, I.M.; White, S.H.; Von Heijne, G. Recognition of transmembrane helices by the endoplasmic reticulum translocon. Nature 2005, 433, 377-381. [CrossRef] [PubMed]

523. Ye, G.; Wu, H.; Huang, J.; Wang, W.; Ge, K.; Li, G.; Zhong, J.; Huang, Q. LAMP2: A major update of the database linking antimicrobial peptides. Database 2020, 2020. [CrossRef] [PubMed]

524. Porto, W.F.; Pires, A.S.; Franco, O.L. Computational tools for exploring sequence databases as a resource for antimicrobial peptides. Biotechnol. Adv. 2017, 35, 337-349. [CrossRef] [PubMed]

525. Pearson, W.R. Rapid and sensitive sequence comparison with FASTP and FASTA. Methods Enzymol. 1990, 183, 63-98. [CrossRef] [PubMed]

526. Altschul, S.F.; Madden, T.L.; Schäffer, A.A.; Zhang, J.; Zhang, Z.; Miller, W.; Lipman, D.J. Gapped BLAST and PSI-BLAST: A new generation of protein database search programs. Nucleic Acids Res. 1997, 25, 3389-3402. [CrossRef]

527. Johnson, L.S.; Eddy, S.R.; Portugaly, E. Hidden Markov model speed heuristic and iterative HMM search procedure. BMC Bioinform. 2010, 11, 431. [CrossRef]

528. Porto, W.F.; Souza, V.A.; Nolasco, D.O.; Franco, O.L. In silico identification of novel hevein-like peptide precursors. Peptides 2012, 38, 127-136. [CrossRef]

529. Liu, S.; Fan, L.; Sun, J.; Lao, X.; Zheng, H. Computational resources and tools for antimicrobial peptides. J. Pept. Sci. 2017, 23, 4-12. [CrossRef] [PubMed]

530. Altschul, S.F.; Gish, W.; Miller, W.; Myers, E.W.; Lipman, D.J. Basic local alignment search tool. J. Mol. Biol. 1990, 215 , 403-410. [CrossRef]

531. Sievers, F.; Wilm, A.; Dineen, D.; Gibson, T.J.; Karplus, K.; Li, W.; Lopez, R.; McWilliam, H.; Remmert, M.; Söding, J.; et al. Fast, scalable generation of high-quality protein multiple sequence alignments using Clustal Omega. Mol. Syst. Biol. 2011, 7, 539. [CrossRef]

532. Wang, P.; Hu, L.; Liu, G.; Jiang, N.; Chen, X.; Xu, J.; Zheng, W.; Li, L.; Tan, M.; Chen, Z.; et al. Prediction of antimicrobial peptides based on sequence alignment and feature selection methods. PloS ONE 2011, 6, e18476. [CrossRef] [PubMed]

533. Hunter, S.; Apweiler, R.; Attwood, T.K.; Bairoch, A.; Bateman, A.; Binns, D.; Bork, P.; Das, U.; Daugherty, L.; Duquenne, L.; et al. InterPro: The integrative protein signature database. Nucleic Acids Res. 2009, 37, D211-D215. [CrossRef] [PubMed]

534. Finn, R.D.; Bateman, A.; Clements, J.; Coggill, P.; Eberhardt, R.Y.; Eddy, S.R.; Heger, A.; Hetherington, K.; Holm, L.; Mistry, J.; et al. Pfam: The protein families database. Nucleic Acids Res. 2014, 42. [CrossRef] [PubMed]

535. Franco, O.L. Peptide promiscuity: An evolutionary concept for plant defense. FEBS Lett. 2011, 585, 995-1000. [CrossRef] [PubMed]

536. Silverstein, K.A.T.; Moskal, W.A.; Wu, H.C.; Underwood, B.A.; Graham, M.A.; Town, C.D.; VandenBosch, K.A. Small cysteine-rich peptides resembling antimicrobial peptides have been under-predicted in plants. Plant J. 2007, 51, 262-280. [CrossRef] [PubMed]

537. Jordan, M.I.; Mitchell, T.M. Machine learning: Trends, perspectives, and prospects. Science 2015, 349, 255-260. [CrossRef] [PubMed]

538. Kotsiantis, S.B. Supervised machine learning: A review of classification techniques. Informatica 2007, 31, 249-268. [CrossRef]

539. Francis, L. Unsupervised learning. In Predictive Modeling Applications in Actuarial Science: Volume I: Predictive Modeling Techniques; Cambridge University Press: Cambridge, UK, 2014; pp. 280-312. ISBN 9781139342674.

540. Lee, M.W.; Lee, E.Y.; Ferguson, A.L.; Wong, G.C.L. Machine learning antimicrobial peptide sequences: Some surprising variations on the theme of amphiphilic assembly. Curr. Opin. Colloid Interface Sci. 2018, 38, 204-213. [CrossRef] [PubMed]

541. Jumper, J.; Evans, R.; Pritzel, A.; Green, T.; Figurnov, M.; Ronneberger, O.; Tunyasuvunakool, K.; Bates, R.; Žídek, A.; Potapenko, A.; et al. Highly accurate protein structure prediction with AlphaFold. Nature 2021. [CrossRef] [PubMed] 
542. Hua, S.; Sun, Z. Support vector machine approach for protein subcellular localization prediction. Bioinformatics 2001, 17, 721-728. [CrossRef] [PubMed]

543. Ng, X.Y.; Rosdi, B.A.; Shahrudin, S. Prediction of antimicrobial peptides based on sequence alignment and support vector machine-pairwise algorithm utilizing LZ-complexity. Biomed Res. Int. 2015, 2015. [CrossRef] [PubMed]

544. Breiman, L. Random Forrests. Mach. Learn. 2001, 45, 5-32. [CrossRef]

545. Khatun, S.; Hasan, M.; Kurata, H. Efficient computational model for identification of antitubercular peptides by integrating amino acid patterns and properties. FEBS Lett. 2019, 593, 3029-3039. [CrossRef]

546. Poorinmohammad, N.; Hamedi, J.; Moghaddam, M.H.A.M. Sequence-based analysis and prediction of lantibiotics: A machine learning approach. Comput. Biol. Chem. 2018, 77, 199-206. [CrossRef] [PubMed]

547. Su, X.; Xu, J.; Yin, Y.; Quan, X.; Zhang, H. Antimicrobial peptide identification using multi-scale convolutional network. BMC Bioinform. 2019, 20. [CrossRef]

548. Wang, C.; Garlick, S.; Zloh, M. Deep learning for novel antimicrobial peptide design. Biomolecules 2021, 11, 471. [CrossRef]

549. Sharma, R.; Shrivastava, S.; Kumar Singh, S.; Kumar, A.; Saxena, S.; Kumar Singh, R. AniAMPpred: Artificial intelligence guided discovery of novel antimicrobial peptides in animal kingdom. Brief. Bioinform. 2021. [CrossRef]

550. Waghu, F.H.; Barai, R.S.; Gurung, P.; Idicula-Thomas, S. CAMPR3: A database on sequences, structures and signatures of antimicrobial peptides. Nucleic Acids Res. 2016, 44, D1094-D1097. [CrossRef] [PubMed]

551. Feng, P.; Wang, Z.; Yu, X. Predicting antimicrobial peptides by using increment of diversity with quadratic discriminant analysis method. IEEE/ACM Trans. Comput. Biol. Bioinforma. 2019, 16, 1309-1312. [CrossRef] [PubMed]

552. Chang, K.Y.; Lin, T.P.; Shih, L.Y.; Wang, C.K. Analysis and prediction of the critical regions of antimicrobial peptides based on conditional random fields. PLoS ONE 2015, 10, e0119490. [CrossRef] [PubMed]

553. Wang, Y.; Zhao, T.; Wei, D.; Strandberg, E.; Ulrich, A.S.; Ulmschneider, J.P. How reliable are molecular dynamics simulations of membrane active antimicrobial peptides? Biochim. Biophys. Acta Biomembr. 2014, 1838, 2280-2288. [CrossRef] [PubMed]

554. Ulmschneider, J.P.; Ulmschneider, M.B. Molecular Dynamics Simulations Are Redefining Our View of Peptides Interacting with Biological Membranes. Acc. Chem. Res. 2018, 51, 1106-1116. [CrossRef] [PubMed]

555. Tsai, C.W.; Hsu, N.Y.; Wang, C.H.; Lu, C.Y.; Chang, Y.; Tsai, H.H.G.; Ruaan, R.C. Coupling Molecular Dynamics Simulations with Experiments for the Rational Design of Indolicidin-Analogous Antimicrobial Peptides. J. Mol. Biol. 2009, 392, 837-854. [CrossRef] [PubMed]

556. Chakraborty, H.J.; Gangopadhyay, A.; Datta, A. Prediction and characterisation of lantibiotic structures with molecular modelling and molecular dynamics simulations. Sci. Rep. 2019, 9. [CrossRef]

557. Waghu, F.H.; Joseph, S.; Ghawali, S.; Martis, E.A.; Madan, T.; Venkatesh, K.V.; Idicula-Thomas, S. Designing antibacterial peptides with enhanced killing kinetics. Front. Microbiol. 2018, 9. [CrossRef] [PubMed]

558. Talandashti, R.; Mehrnejad, F.; Rostamipour, K.; Doustdar, F.; Lavasanifar, A. Molecular Insights into Pore Formation Mechanism, Membrane Perturbation, and Water Permeation by the Antimicrobial Peptide Pleurocidin: A Combined All-Atom and CoarseGrained Molecular Dynamics Simulation Study. J. Phys. Chem. B 2021, 125, 7163-7176. [CrossRef] [PubMed]

559. Catte, A.; Wilson, M.R.; Walker, M.; Oganesyan, V.S. Antimicrobial action of the cationic peptide, chrysophsin-3: A coarse-grained molecular dynamics study. Soft Matter 2018, 14, 2796-2807. [CrossRef] [PubMed]

560. Lyu, Y.; Xiang, N.; Zhu, X.; Narsimhan, G. Potential of mean force for insertion of antimicrobial peptide melittin into a pore in mixed DOPC/DOPG lipid bilayer by molecular dynamics simulation. J. Chem. Phys. 2017, 146. [CrossRef] [PubMed]

561. Liu, S.; Bao, J.; Lao, X.; Zheng, H. Novel 3D Structure Based Model for Activity Prediction and Design of Antimicrobial Peptides. Sci. Rep. 2018, 8. [CrossRef]

562. Petkov, P.; Lilkova, E.; Ilieva, N.; Litov, L. Self-association of antimicrobial peptides: A molecular dynamics simulation study on bombinin. Int. J. Mol. Sci. 2019, 20, 5450. [CrossRef] [PubMed]

563. Bogdanova, L.R.; Valiullina, Y.A.; Faizullin, D.A.; Kurbanov, R.K.; Ermakova, E.A. Spectroscopic, zeta potential and molecular dynamics studies of the interaction of antimicrobial peptides with model bacterial membrane. Spectrochim. Acta Part A Mol. Biomol. Spectrosc. 2020, 242. [CrossRef] [PubMed]

564. Lai, P.K.; Kaznessis, Y.N. Insights into membrane translocation of protegrin antimicrobial peptides by multistep molecular dynamics simulations. In Proceedings of the AIChE Annual Meeting, Pittsburgh, PA, USA, 28 October-2 November 2018; 2018; 3 , pp. 6056-6065. [CrossRef]

565. Zhao, L.; Cao, Z.; Bian, Y.; Hu, G.; Wang, J.; Zhou, Y. Molecular dynamics simulations of human antimicrobial peptide LL-37 in model POPC and POPG lipid bilayers. Int. J. Mol. Sci. 2018, 19, 1186. [CrossRef] [PubMed]

566. Sur, S.; Romo, T.D.; Grossfield, A. Selectivity and Mechanism of Fengycin, an Antimicrobial Lipopeptide, from Molecular Dynamics. J. Phys. Chem. B 2018, 122, 2219-2226. [CrossRef] [PubMed]

567. Das, P.; Sercu, T.; Wadhawan, K.; Padhi, I.; Gehrmann, S.; Cipcigan, F.; Chenthamarakshan, V.; Strobelt, H.; dos Santos, C.; Chen, P.Y.; et al. Accelerated antimicrobial discovery via deep generative models and molecular dynamics simulations. Nat. Biomed. Eng. 2021, 5, 613-623. [CrossRef]

568. Wang, C.K.L.; Kaas, Q.; Chiche, L.; Craik, D.J. CyBase: A database of cyclic protein sequences and structures, with applications in protein discovery and engineering. Nucleic Acids Res. 2008, 36. [CrossRef]

569. Lata, S.; Sharma, B.K.; Raghava, G.P.S. Analysis and prediction of antibacterial peptides. BMC Bioinform. 2007, 8, 263. [CrossRef] [PubMed] 
570. Li, J.; Qu, X.; He, X.; Duan, L.; Wu, G.; Bi, D.; Deng, Z.; Liu, W.; Ou, H.Y. ThioFinder: A Web-Based Tool for the Identification of Thiopeptide Gene Clusters in DNA Sequences. PLoS ONE 2012, 7. [CrossRef] [PubMed]

571. Thakur, N.; Qureshi, A.; Kumar, M. AVPpred: Collection and prediction of highly effective antiviral peptides. Nucleic Acids Res. 2012, 40. [CrossRef] [PubMed]

572. Joseph, S.; Karnik, S.; Nilawe, P.; Jayaraman, V.K.; Idicula-Thomas, S. ClassAMP: A prediction tool for classification of antimicrobial peptides. IEEE/ACM Trans. Comput. Biol. Bioinforma. 2012, 9, 1535-1538. [CrossRef] [PubMed]

573. Kamech, N.; Vukičević, D.; Ladram, A.; Piesse, C.; Vasseur, J.; Bojović, V.; Simunić, J.; Juretić, D. Improving the selectivity of antimicrobial peptides from anuran skin. J. Chem. Inf. Model. 2012, 52, 3341-3351. [CrossRef] [PubMed]

574. Novković, M.; Simunić, J.; Bojović, V.; Tossi, A.; Juretić, D. DADP: The database of anuran defense peptides. Bioinformatics 2012, 28, 1406-1407. [CrossRef] [PubMed]

575. Piotto, S.P.; Sessa, L.; Concilio, S.; Iannelli, P. YADAMP: Yet another database of antimicrobial peptides. Int. J. Antimicrob. Agents 2012, 39, 346-351. [CrossRef]

576. Holton, T.A.; Pollastri, G.; Shields, D.C.; Mooney, C. CPPpred: Prediction of cell penetrating peptides. Bioinformatics 2013, 29, 3094-3096. [CrossRef]

577. Qureshi, A.; Thakur, N.; Kumar, M. HIPdb: A Database of Experimentally Validated HIV Inhibiting Peptides. PLoS ONE 2013, 8. [CrossRef] [PubMed]

578. Lee, H.T.; Lee, C.C.; Yang, J.R.; Lai, J.Z.C.; Chang, K.Y.; Ray, O. A large-scale structural classification of Antimicrobial peptides. Biomed Res. Int. 2015, 2015. [CrossRef] [PubMed]

579. Di Luca, M.; Maccari, G.; Maisetta, G.; Batoni, G. BaAMPs: The database of biofilm-active antimicrobial peptides. Biofouling 2015, 31, 193-199. [CrossRef] [PubMed]

580. Sharma, A.; Gupta, P.; Kumar, R.; Bhardwaj, A. DPABBs: A Novel in silico Approach for Predicting and Designing Anti-biofilm Peptides. Sci. Rep. 2016, 6, 21839. [CrossRef] [PubMed]

581. Nielsen, S.D.; Beverly, R.L.; Qu, Y.; Dallas, D.C. Milk bioactive peptide database: A comprehensive database of milk proteinderived bioactive peptides and novel visualization. Food Chem. 2017, 232, 673-682. [CrossRef] [PubMed]

582. Agrawal, P.; Khater, S.; Gupta, M.; Sain, N.; Mohanty, D. RiPPMiner: A bioinformatics resource for deciphering chemical structures of RiPPs based on prediction of cleavage and cross-links. Nucleic Acids Res. 2017, 45, W80-W88. [CrossRef] [PubMed]

583. Meher, P.K.; Sahu, T.K.; Saini, V.; Rao, A.R. Predicting antimicrobial peptides with improved accuracy by incorporating the compositional, physico-chemical and structural features into Chou's general PseAAC. Sci. Rep. 2017, 7, 1-12. [CrossRef] [PubMed]

584. Gómez, E.A.; Giraldo, P.; Orduz, S. InverPep: A database of invertebrate antimicrobial peptides. J. Glob. Antimicrob. Resist. 2017, 8, 13-17. [CrossRef] [PubMed]

585. Van Heel, A.J.; De Jong, A.; Song, C.; Viel, J.H.; Kok, J.; Kuipers, O.P. BAGEL4: A user-friendly web server to thoroughly mine RiPPs and bacteriocins. Nucleic Acids Res. 2018, 46, W278-W281. [CrossRef] [PubMed]

586. Veltri, D.; Kamath, U.; Shehu, A. Deep learning improves antimicrobial peptide recognition. Bioinformatics 2018, 34, $2740-2747$. [CrossRef] [PubMed]

587. Gull, S.; Shamim, N.; Minhas, F. AMAP: Hierarchical multi-label prediction of biologically active and antimicrobial peptides. Comput. Biol. Med. 2019, 107, 172-181. [CrossRef] [PubMed]

588. Beltrán Lissabet, J.F.; Belén, L.H.; Farias, J.G. AntiVPP 1.0: A portable tool for prediction of antiviral peptides. Comput. Biol. Med. 2019, 107, 127-130. [CrossRef] [PubMed]

589. Schaduangrat, N.; Nantasenamat, C.; Prachayasittikul, V.; Shoombuatong, W. Meta-iavp: A sequence-based meta-predictor for improving the prediction of antiviral peptides using effective feature representation. Int. J. Mol. Sci. 2019, 20, 5743. [CrossRef] [PubMed]

590. Boopathi, V.; Subramaniyam, S.; Malik, A.; Lee, G.; Manavalan, B.; Yang, D.C. MACppred: A support vector machine-based meta-predictor for identification of anticancer peptides. Int. J. Mol. Sci. 2019, 20, 1964. [CrossRef] [PubMed]

591. Yan, J.; Bhadra, P.; Li, A.; Sethiya, P.; Qin, L.; Tai, H.K.; Wong, K.H.; Siu, S.W.I. Deep-AmPEP30: Improve Short Antimicrobial Peptides Prediction with Deep Learning. Mol. Ther. Nucleic Acids 2020, 20, 882-894. [CrossRef] [PubMed]

592. Burdukiewicz, M.; Sidorczuk, K.; Rafacz, D.; Pietluch, F.; Chilimoniuk, J.; Rödiger, S.; Gagat, P. Proteomic Screening for Prediction and Design of Antimicrobial Peptides with AmpGram. Int. J. Mol. Sci. 2020, 21, 4310. [CrossRef] [PubMed]

593. Kavousi, K.; Bagheri, M.; Behrouzi, S.; Vafadar, S.; Atanaki, F.F.; Lotfabadi, B.T.; Ariaeenejad, S.; Shockravi, A.; MoosaviMovahedi, A.A. IAMPE: NMR-assisted computational prediction of antimicrobial peptides. J. Chem. Inf. Model. 2020, 60, 4691-4701. [CrossRef] [PubMed]

594. Burdukiewicz, M.; Sidorczuk, K.; Rafacz, D.; Pietluch, F.; Bąkała, M.; Słowik, J.; Gagat, P. Cancergram: An effective classifier for differentiating anticancer from antimicrobial peptides. Pharmaceutics 2020, 12, 1045. [CrossRef]

595. Fu, H.; Cao, Z.; Li, M.; Wang, S. ACEP: Improving antimicrobial peptides recognition through automatic feature fusion and amino acid embedding. BMC Genom. 2020, 21. [CrossRef] [PubMed]

596. Shi, G.; Kang, X.; Dong, F.; Liu, Y.; Zhu, N.; Hu, Y.; Xu, H.; Lao, X.; Zheng, H. DRAMP 3.0: An enhanced comprehensive data repository of antimicrobial peptides. Nucleic Acids Res. 2021. [CrossRef] [PubMed]

597. Govindaraj Vaithinathan, A.; Vanitha, A. WHO global priority pathogens list on antibiotic resistance: An urgent need for action to integrate One Health data. Perspect. Public Health 2018, 138, 87-88. [CrossRef] [PubMed] 
598. De Oliveira, D.M.P.; Forde, B.M.; Kidd, T.J.; Harris, P.N.A.; Schembri, M.A.; Beatson, S.A.; Paterson, D.L.; Walker, M.J. Antimicrobial resistance in ESKAPE pathogens. Clin. Microbiol. Rev. 2020, 33. [CrossRef] [PubMed]

599. Eckert, R. Road to clinical efficacy: Challenges and novel strategies for antimicrobial peptide development. Future Microbiol. 2011, 6, 635-651. [CrossRef] [PubMed]

600. Zasloff, M. Antimicrobial peptides of multicellular organisms: My perspective. In Advances in Experimental Medicine and Biology; Springer: Singapore, 2019; Volume 1117, pp. 3-6.

601. Bucki, R.; Leszczyńska, K.; Namiot, A.; Sokołowski, W. Cathelicidin LL-37: A multitask antimicrobial peptide. Arch. Immunol. Ther. Exp. 2010, 58, 15-25. [CrossRef] [PubMed]

602. Agier, J.; Efenberger, M.; Brzezińska-Blaszczyk, E. Cathelicidin impact on inflammatory cells. Cent. Eur. J. Immunol. 2015, 40, 225-235. [CrossRef] [PubMed]

603. Usmani, S.S.; Bedi, G.; Samuel, J.S.; Singh, S.; Kalra, S.; Kumar, P.; Ahuja, A.A.; Sharma, M.; Gautam, A.; Raghava, G.P.S. THPdb: Database of FDA-approved peptide and protein therapeutics. PLOS ONE 2017, 12. [CrossRef] [PubMed]

604. Schaison, G.; Graninger, W.; Bouza, E. Teicoplanin in the treatment of serious infection. J. Chemother. 2000, 12 (Suppl. 5), 26-33. [CrossRef] [PubMed]

605. Di, L. Strategic Approaches to Optimizing Peptide ADME Properties. AAPS J. 2015, 17, 134-143. [CrossRef] [PubMed]

606. Irazazabal, L.N.; Porto, W.F.; Ribeiro, S.M.; Casale, S.; Humblot, V.; Ladram, A.; Franco, O.L. Selective amino acid substitution reduces cytotoxicity of the antimicrobial peptide mastoparan. Biochim. Biophys. Acta Biomembr. 2016, 1858, 2699-2708. [CrossRef] [PubMed]

607. Matsuzaki, K. Control of cell selectivity of antimicrobial peptides. Biochim. Biophys. Acta Biomembr. 2009, 1788, 1687-1692. [CrossRef] [PubMed]

608. Gunasekera, S.; Muhammad, T.; Strömstedt, A.A.; Rosengren, K.J.; Göransson, U. Backbone Cyclization and Dimerization of LL-37-Derived Peptides Enhance Antimicrobial Activity and Proteolytic Stability. Front. Microbiol. 2020, 11, 168. [CrossRef] [PubMed]

609. Khaledi, A.; Weimann, A.; Schniederjans, M.; Asgari, E.; Kuo, T.; Oliver, A.; Cabot, G.; Kola, A.; Gastmeier, P.; Hogardt, M.; et al. Predicting antimicrobial resistance in Pseudomonas aeruginosa with machine learning-enabled molecular diagnostics. EMBO Mol. Med. 2020, 12, e10264. [CrossRef] [PubMed]

610. Mehrnejad, F.; Zarei, M. Molecular dynamics simulation study of the interaction of piscidin 1 with dppc bilayers: Structure-activity relationship. J. Biomol. Struct. Dyn. 2010, 27, 551-559. [CrossRef]

611. Zhu, Y.; Lu, J.; Han, M.L.; Jiang, X.; Azad, M.A.K.; Patil, N.A.; Lin, Y.W.; Zhao, J.; Hu, Y.; Yu, H.H.; et al. Polymyxins Bind to the Cell Surface of Unculturable Acinetobacter baumannii and Cause Unique Dependent Resistance. Adv. Sci. 2020, 7. [CrossRef] [PubMed]

612. Jiang, X.; Yang, K.; Yuan, B.; Han, M.; Zhu, Y.; Roberts, K.D.; Patil, N.A.; Li, J.; Gong, B.; Hancock, R.E.W.; et al. Molecular dynamics simulations informed by membrane lipidomics reveal the structure-interaction relationship of polymyxins with the lipid A-based outer membrane of Acinetobacter baumannii. J. Antimicrob. Chemother. 2020, 75, 3534-3543. [CrossRef] [PubMed]

613. Chen, C.H.; Starr, C.G.; Troendle, E.; Wiedman, G.; Wimley, W.C.; Ulmschneider, J.P.; Ulmschneider, M.B. Simulation-Guided Rational de Novo Design of a Small Pore-Forming Antimicrobial Peptide. J. Am. Chem. Soc. 2019, 141, 4839-4848. [CrossRef] [PubMed]

614. Kleandrova, V.V.; Ruso, J.M.; Speck-Planche, A.; Dias Soeiro Cordeiro, M.N. Enabling the Discovery and Virtual Screening of Potent and Safe Antimicrobial Peptides. Simultaneous Prediction of Antibacterial Activity and Cytotoxicity. ACS Comb. Sci. 2016, 18, 490-498. [CrossRef] [PubMed]

615. Li, F.F.; Brimble, M.A. Using chemical synthesis to optimise antimicrobial peptides in the fight against antimicrobial resistance. In Proceedings of the Pure and Applied Chemistry, Bangkok, Thailand, 7-8 February 2019; 2019; Volume 91, pp. $181-198$.

616. Wu, Z.; Li, Y.; Zhang, L.; Ding, Z.; Shi, G. Microbial production of small peptide: Pathway engineering and synthetic biology. Microb. Biotechnol. 2021. [CrossRef] [PubMed] 